\title{
11. ALTERATION MINERALOGY AND CHEMISTRY OF THE UPPER OCEANIC CRUST FROM HOLE 896A, COSTA RICA RIFT ${ }^{1}$
}

\author{
Christine Laverne, ${ }^{2}$ Abdeltif Belarouchi, ${ }^{2}$ and José Honnorez ${ }^{3}$
}

\begin{abstract}
During Leg 148, Hole 896A was drilled $1 \mathrm{~km}$ southeast of Hole 504B. One of the scientific objectives of drilling Hole 896A was to compare the alteration features of the upper oceanic crust to those of the upper part of Hole 504 basalts, and to find evidence of the possible influence of their respective geothermal contexts on these features.

In this paper, basalts sampled along the $290 \mathrm{~m}$ drilled into the basement of Hole $896 \mathrm{~A}$ were studied to document the mineralogy, petrology, and chemistry associated with low-temperature alteration and to compare these features with the upper part of Hole 504B, which was altered at low temperature. The methods used were optical microscopy (reflected and transmitted light), $\mathrm{X}$-ray diffraction, electron microprobe, and bulk-rock chemical analyses.

Alteration effects in Hole 896A basalts are chiefly visible as veins, as breccia cements, and as variously colored halos that are 3 to $50 \mathrm{~mm}$ in thickness. No trend with depth downhole is apparent in either the alteration mineralogy and chemistry or in the overall extent to which alteration proceeded.

A strong lithological control on the extent and style of alteration is readily apparent in the section studied. Fresh basaltic glass is common, because of the difficult access to fluids in this amorphous material. The large number of highly oxidized basalts contained in the massive units, compared to the discrete oxidative alteration of the pillow basalts units, is explained by the fact that the diffusion of the fluids along grain boundaries is easier in the coarse-grained basalts composing the massive units.
\end{abstract}

Clay minerals are the most common and abundant secondary minerals in Hole 896A basalts. Most of them are saponites. Celadonite, celadonite-nontronite mixtures, celadonite-nontronite-saponite mixtures, and saponite-celadonite-iron oxide mixtures also occur commonly. These celadonite-bearing minerals are restricted to black halos, brown halos, and the internal part of the compound red halos. Calcite and aragonite are abundant in veins. Phillipsite, chabazite, and pyrite are the least abundant secondary minerals.

Seawater is the main fluid involved in the formation of oxidized (red and brown) alteration halos. Alteration started with an oxidative stage, with the replacement of olivine by iddingsite and Fe-hydroxides and the precipitation of these minerals in the primary voids. The chemical composition of the fluid evolved while moving into the basalt, leading to a reducing alteration stage with saponite precipitation in the adjacent gray basalt. Most of the late-stage secondary minerals (zeolites and Ca-carbonates) probably formed largely in response to an increase in $\mathrm{pH}$, because of the consumption of $\mathrm{H}^{+}$related to the breakdown of plagioclase.

The occurrence of celadonite-nontronite and the enrichment in $\mathrm{K}_{\text {and }} \mathrm{Fe}_{\mathrm{t}}$ of Hole 896A black halos imply the contribution of Fe-rich, diluted hydrothermal fluids during their formation. We propose that the most internal zone of the compound red halos and the brown halos represent early black halos which would have been oxidized later by seawater.

The major mineralogical and chemical features of alteration evidenced in the $310 \mathrm{~m}$ of basalts forming the upper pillow alteration zone (UPAZ) of Hole 504B are similar to those observed in Hole 896A. However, the oxidizing, seawater dominated, alteration seems to be more widespread at Site 896, suggesting higher water/rock ratios, related to a higher primary permeability.

\section{INTRODUCTION}

Site 896 is located at $1^{\circ} 13.006^{\prime} \mathrm{N}, 83^{\circ} 43.392^{\prime} \mathrm{W}, 202 \mathrm{~km}$ south of the Costa Rica Rift, the easternmost segment of the Galapagos Spreading Center, and $1 \mathrm{~km}$ southeast of the famous Hole 504B, the deepest hole cored in the oceanic crust (Fig. 1). Assuming a halfspreading rate of $3.6 \mathrm{~cm} / \mathrm{yr}$, Site 896 is situated in an oceanic crust that is 28,000 years older than Hole 504B basement, which is $5.9 \mathrm{~m}$. y. old. Site 896 is situated on a local heat-flow maximum over a basement topographic high (water depth: $3439.8 \mathrm{~m}$ ). The basement topographic high is situated over the top of a tilted basement fault block, where low-temperature hydrothermal fluids are upwelling through most of the 179-m sediment section that was cored during Leg 111

'Alt, J.C., Kinoshita, H., Stokking, L.B., and Michael, P.J. (Eds.), 1996. Proc. ODP, Sci. Results, 148: College Station, TX (Ocean Drilling Program).

${ }^{2}$ Laboratoire de Pétrologie Magmatique, URA CNRS 1277, Faculté des Sciences et Techniques de Saint-Jérôme, Avenue Escadrille Normandie-Niemen, 13397 Marseille Cedex 20, France. lacte@vmesal1.u-3mrs.fr

${ }^{3}$ Institut de Géologie and Centre de Géochemie de la Surface, Université Louis Pasteur, 1 rue Blessig, F-67084 Strasbourg Cedex, France. honnorez@illite.u-strasbg.fr
(Shipboard Scientific Party, 1988; Fisher et al., 1990; Shipboard Scientific Party, 1993).

Hole $896 \mathrm{~A}$ penetrated to $469 \mathrm{mbsf}$ ( $290 \mathrm{~m}$ into basement). Four types of volcanic units were identified: massive basalts (representing $38 \%$ of the cored section), pillow lavas $(57 \%)$, breccias $(5 \%)$, and dikes $(<1 \%)$. Because recovery averaged approximately $30 \%$, the actual proportions of breccias, and to a lesser extent, of pillow lavas, is probably underestimated, as in the volcanics from Hole 504B (M. Ayadi et al., unpubl. data).

Hole $896 \mathrm{~A}$ rocks exhibit the effects of low-temperature $\left(<100^{\circ} \mathrm{C}\right)$ seafloor alteration. Background reducing alteration, characterized by gray rocks and $\mathrm{Mg}$-smectite, is pervasive. Oxidative alteration is represented by alteration halos adjacent to smectite veins and is more pervasive in the lower section. Veins are common in Hole 896A rocks. These veins and breccia cements are composed of $\mathrm{Mg}$-smectite and $\mathrm{Ca}$-carbonate. Many of these are proposed to have formed by the crack-seal mechanism, which implies relatively high fluid pore pressures to cause hydraulic fracturing (Shipboard Scientific Party, 1993).

This paper documents the mineralogy, petrography, and bulkrock geochemistry associated with alteration of the basalts from Hole 


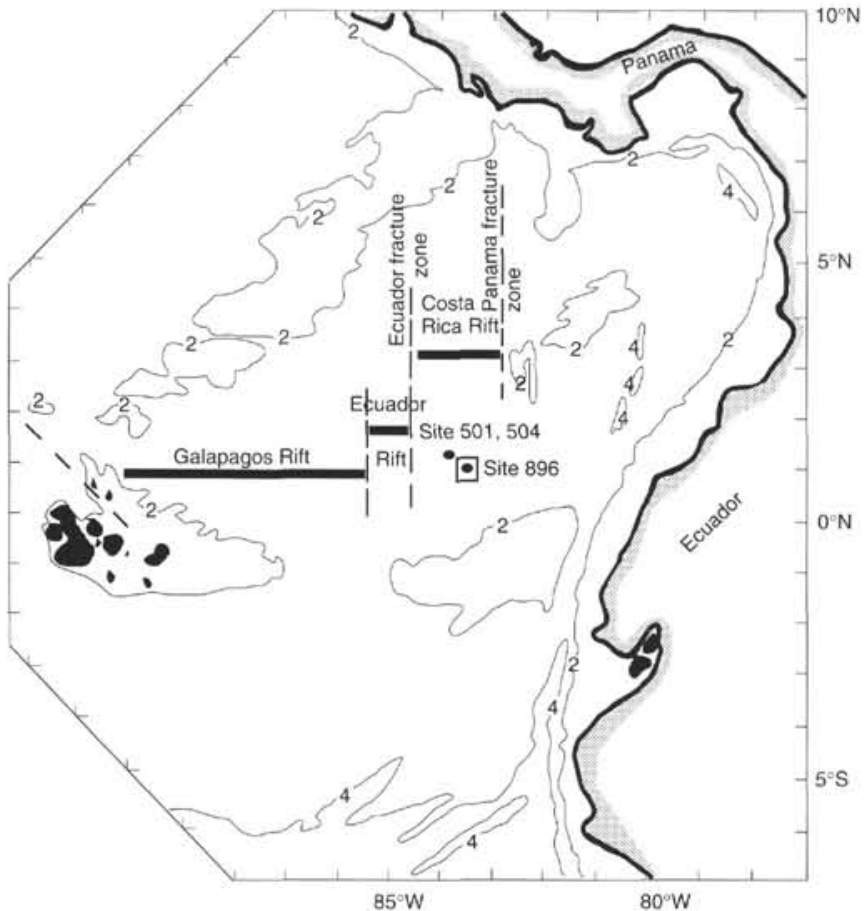

Figure I. Location of Hole 896A. $2=2000 \mathrm{~m}$ isobath, $4=4000 \mathrm{~m}$ isobath.

$896 \mathrm{~A}$, drilled during Leg 148, to constrain the thermal history, the water-rock ratio, and the compositions of involved fluids. These data are briefly compared with previous results from the upper volcanics in Hole 504B, to provide evidence for the possible influence of the different geological settings of these sites on the alteration processes of the upper oceanic crust.

\section{ANALYTICAL METHODS}

Forty-eight thin sections from Hole 896A were prepared and mineral chemistry was obtained using the Camebax electron microprobe of the University of Montpellier, France, equipped with wavelength dispersive spectrometers. Well-characterized natural and synthetic standards were used. For magmatic minerals, the following operating conditions were used: $15-\mathrm{kV}$ accelerating voltage, $15-\mathrm{nA}$ specimen current, 1-mm spot size, 20-s counting time. Because of their instability under the electron beam, the following conditions were used for secondary minerals, and particularly for zeolites: $20-\mathrm{kV}$ accelerating voltage, 10-nA specimen current, 10- $\mu \mathrm{m}$ spot size, 20-s counting time.

The identification of phyllosilicates by X-ray diffraction was performed at the University of Aix-Marseille III. Minerals were scraped from veins and crushed in a small agate mortar. Powders obtained were then either studied as unoriented aggregates or deposited in a drop of water to orient particles. Three runs were made for each powder: air dried, after saturation by ethylene glycol, and after heating at $300^{\circ} \mathrm{C}$ for $4 \mathrm{hr}$. To determine the di- or trioctahedral nature of the phyllosilicates, the $(060)$ peak was identified by using quartz as an internal standard. The method of separation recommended by Alt (1984) was used to study clay minerals occurring in small amounts in bulk rocks.

The samples selected for bulk-rock chemical study at the University of Aix-Marseille III were crushed and ground in an agate mortar. To avoid problems because of the refractory character of some elements such as $\mathrm{Zr}$, the fusion technique by lithium metaborate $\left(\mathrm{LiBO}_{2}\right)$ was used (Germanique, 1994). Major and trace elements, except alkalies, were determined by inductively coupled plasma-emission spectroscopy (Sequential Jobin-Yvon 38-III) at the University of Aix-Marseille III. Alkalies were analyzed by atomic absorption.

\section{PRIMARY MINERALOGY}

Basalts recovered from Hole $896 \mathrm{~A}$ are sparsely to highly plagioclase-olivine phyric tholeiites, commonly containing spinel. Clinopyroxene is also present as a phenocryst in some units. To determine chemical variations during alteration at the mineral scale (e.g., olivine replaced by saponite) for further study, we analyzed olivine, clinopyroxene, plagioclase, titanomagnetite, and $\mathrm{Cr}$-spinel of some basalts from Hole 896A (Table 1).

\section{ALTERATION FEATURES IN HAND SPECIMEN}

All of the rock pieces recovered in Hole 896A are altered to some extent ( $1 \%-10 \%$ secondary minerals). However, fresh glass is commonly present on pillow rims. Alteration effects are chiefly manifest as variously colored halos or bands, as veins, and as breccia cements.

Three types of halos, distinguished on the basis of their color, are described by the Shipboard Scientific Party (1993). Their features are given below, together with those of a fourth type of halo identified in this study.

1. The compound red halos ( $\mathrm{CRH}$ ) are related to the dark green (in hand specimens) saponite veins. From the vein walls to the inner part of the sample, one successively observes (Fig. 2) (1) a dark redbrown, 10-mm-thick halo (CRHA); (2) a thin (1 to $2 \mathrm{~mm}$ ), bright red halo (CRHB); (3) a thicker (up to $40 \mathrm{~mm}$ ) yellowish halo (CRHC); (4) gray, unoxidized, adjacent basalt ( $\mathrm{G}$ adj). The contact between CRHC and $\mathrm{G}$ adj is sharp and underlined by a highly oxidized band. The red and yellow colors are caused by the occurrence of iddingsite and Fe-oxyhydroxides. These spectacular halos are most common in the coarser grained basalts. They are less abundant and less visible in the fine-grained lavas.

2. The simple red halos $(R H)$ are less common than compound ones. They are also related to saponite veins, and are similar to $\mathrm{CRHC}$. Their thickness ranges from 3 to $10 \mathrm{~mm}$. The contact with the gray adjacent basalt ( $\mathrm{G}$ adj) is sharp.

3. The pale brown halos $(\mathrm{BrH})$ display diffuse, irregular boundaries and are a few millimeters thick. They were found only in the pillow lavas.

4. The black halos (BH) are 10 to $30 \mathrm{~mm}$ thick (Fig. 3). The contact with the gray adjacent basalt ( $\mathrm{G}$ adj) is sharp. Black halos were observed in only three samples.

\section{SECONDARY MINERAL IDENTIFICATION}

The distribution of secondary minerals vs. depth is presented in Figure 4 . The clay minerals are the most abundant secondary minerals in the Hole $896 \mathrm{~A}$ basalts. The other alteration products and minerals-goethite, other unspecified $\mathrm{Fe}$-oxyhydroxides, iddingsite, Cacarbonates, zeolites and pyrite-occur in smaller quantities. The identification of secondary minerals is based on optical examination, electron microprobe analysis, and X-ray diffraction analysis.

\section{Clay Minerals}

Clay minerals commonly occur as the main vein component, as fillings in miarolitic voids and vesicles, and as replacement of olivine, plagioclase, and glass. X-ray diffraction data of clay minerals 
Table 1. Representative olivine, clinopyroxene, plagioclase, titanomagnetite, and Cr-spinel analyses from Hole 896A.

\begin{tabular}{|c|c|c|c|c|c|c|c|c|c|c|c|c|c|c|c|}
\hline $\begin{array}{l}\text { Core, section: } \\
\text { Interval (cm): } \\
\text { Piece no.: } \\
\text { Depth (mbsf): } \\
\text { Mineral: } \\
\text { Analysis no.: }\end{array}$ & $\begin{array}{c}28 \mathrm{R}-1 \\
107-108 \\
18 \mathrm{~B} \\
440.9 \\
\text { Olivine } \\
\text { M62 }\end{array}$ & $\begin{array}{c}28 \mathrm{R}-1 \\
107-108 \\
18 \mathrm{~B} \\
440.9 \\
\text { Olivine } \\
\text { M64 }\end{array}$ & $\begin{array}{l}9 \mathrm{R}-2 \\
14-17 \\
2 \\
268.2 \\
\text { Plag m } \\
\text { Mill }\end{array}$ & $\begin{array}{l}9 \mathrm{R}-2 \\
14-17 \\
2 \\
268.2 \\
\text { Plag p } \\
\text { M132 }\end{array}$ & $\begin{array}{c}10 \mathrm{R}-1 \\
57-60 \\
8 \mathrm{~A} \\
276.9 \\
\text { Plag p } \\
\text { M186 }\end{array}$ & $\begin{array}{c}17 R-3 \\
43-45 \\
4 \\
346.8 \\
\text { Plag m } \\
\text { M110 }\end{array}$ & $\begin{array}{l}17 \mathrm{R}-4 \\
15-20 \\
2 \mathrm{C} \\
348.1 \\
\text { Plag p } \\
\text { M152 }\end{array}$ & $\begin{array}{c}18 \mathrm{R}-1 \\
87-90 \\
9 \mathrm{~A} \\
353.2 \\
\text { Plag m } \\
\text { M93 }\end{array}$ & $\begin{array}{c}18 \mathrm{R}-1 \\
87-90 \\
9 \mathrm{~A} \\
353.2 \\
\text { Plag p } \\
\text { M132 }\end{array}$ & $\begin{array}{c}21 R-1 \\
84-91 \\
14 \\
373.7 \\
\text { Plag m } \\
\text { M67 }\end{array}$ & $\begin{array}{c}21 \mathrm{R}-1 \\
84-91 \\
14 \\
373.7 \\
\text { Plag p } \\
\text { M72 }\end{array}$ & $\begin{array}{c}23 R-2 \\
0-6 \\
1 \mathrm{~A} \\
393.6 \\
\text { Plag m } \\
\text { M30 }\end{array}$ & $\begin{array}{c}23 R-2 \\
0-6 \\
1 \mathrm{~A} \\
393.6 \\
\text { Plag p } \\
\text { M40 }\end{array}$ & $\begin{array}{c}24 \mathrm{R}-1 \\
88-92 \\
6 \\
402.7 \\
\text { Plag p } \\
\text { M83 }\end{array}$ & $\begin{array}{c}28 R-1 \\
107-108 \\
18 B \\
440.9 \\
\text { Plag p } \\
\text { M44 }\end{array}$ \\
\hline $\begin{array}{l}\mathrm{SiO}_{2} \\
\mathrm{Al}_{2} \mathrm{O}_{3} \\
\mathrm{FeO}_{1} \\
\mathrm{MnO} \\
\mathrm{MgO} \\
\mathrm{CaO} \\
\mathrm{Na}_{2} \mathrm{O} \\
\mathrm{K}_{2} \mathrm{O} \\
\mathrm{TiO}_{2} \\
\mathrm{Cr}_{2} \mathrm{O}_{3} \\
\text { Total }\end{array}$ & $\begin{array}{r}40.47 \\
0.10 \\
11.31 \\
0.04 \\
47.85 \\
0.33 \\
0.00 \\
0.00 \\
0.00 \\
0.00 \\
100.10\end{array}$ & $\begin{array}{r}40.80 \\
0.07 \\
10.68 \\
0.01 \\
47.82 \\
0.40 \\
0.00 \\
0.00 \\
0.00 \\
0.00 \\
99.78\end{array}$ & $\begin{array}{r}48.58 \\
31.73 \\
0.50 \\
0.00 \\
0.22 \\
16.26 \\
2.28 \\
0.01 \\
0.00 \\
0.00 \\
99.59\end{array}$ & $\begin{array}{r}49.06 \\
31.99 \\
0.79 \\
0.00 \\
0.58 \\
15.53 \\
1.91 \\
0.16 \\
0.00 \\
0.00 \\
100.00\end{array}$ & $\begin{array}{r}48.42 \\
31.64 \\
0.43 \\
0.00 \\
0.25 \\
16.34 \\
2.05 \\
0.00 \\
0.00 \\
0.00 \\
99.13\end{array}$ & $\begin{array}{r}52.05 \\
28.64 \\
1.18 \\
0.04 \\
1.02 \\
13.91 \\
3.33 \\
0.00 \\
0.03 \\
0.05 \\
100.25\end{array}$ & $\begin{array}{r}46.73 \\
32.86 \\
0.21 \\
0.00 \\
0.16 \\
17.54 \\
1.64 \\
0.01 \\
0.00 \\
0.00 \\
99.14\end{array}$ & $\begin{array}{r}48.48 \\
31.77 \\
0.37 \\
0.00 \\
0.24 \\
16.84 \\
1.94 \\
0.02 \\
0.00 \\
0.00 \\
100.66\end{array}$ & $\begin{array}{r}49.06 \\
31.99 \\
0.79 \\
0.00 \\
0.58 \\
15.53 \\
1.91 \\
0.16 \\
0.00 \\
0.00 \\
100.00\end{array}$ & $\begin{array}{r}49.37 \\
31.25 \\
0.61 \\
0.00 \\
0.23 \\
15.74 \\
2.74 \\
0.00 \\
0.00 \\
0.00 \\
99.94\end{array}$ & $\begin{array}{r}49.85 \\
30.77 \\
0.44 \\
0.00 \\
0.24 \\
15.98 \\
2.63 \\
0.00 \\
0.00 \\
0.00 \\
99.92\end{array}$ & $\begin{array}{r}49.64 \\
30.99 \\
0.60 \\
0.00 \\
0.33 \\
15.15 \\
2.99 \\
0.00 \\
0.00 \\
0.00 \\
99.69\end{array}$ & $\begin{array}{r}50.03 \\
30.87 \\
0.27 \\
0.00 \\
0.13 \\
15.48 \\
2.78 \\
0.00 \\
0.00 \\
0.00 \\
99.56\end{array}$ & $\begin{array}{r}47.77 \\
33.33 \\
0.13 \\
0.00 \\
0.16 \\
17.28 \\
1.72 \\
0.01 \\
0.00 \\
0.00 \\
100.41\end{array}$ & $\begin{array}{r}46.72 \\
34.14 \\
0.31 \\
0.00 \\
0.13 \\
17.81 \\
1.38 \\
0.03 \\
0.00 \\
0.00 \\
100.51\end{array}$ \\
\hline $\begin{array}{l}\mathrm{Si} \\
\mathrm{Al} \\
\mathrm{Fe}_{\text {, }} \\
\mathrm{Mn} \\
\mathrm{Mg} \\
\mathrm{Ca} \\
\mathrm{Na} \\
\mathrm{K} \\
\mathrm{Ti}\end{array}$ & $\begin{array}{l}1.00 \\
0.00 \\
0.23 \\
0.00 \\
1.76 \\
0.01 \\
0.00 \\
0.00 \\
0.00\end{array}$ & $\begin{array}{l}1.01 \\
0.00 \\
0.22 \\
0.00 \\
1.76 \\
0.01 \\
0.00 \\
0.00 \\
0.00\end{array}$ & $\begin{array}{l}2.24 \\
1.72 \\
0.02 \\
0.00 \\
0.02 \\
0.80 \\
0.20 \\
0.00 \\
0.00\end{array}$ & $\begin{array}{l}2.25 \\
1.73 \\
0.03 \\
0.00 \\
0.04 \\
0.76 \\
0.17 \\
0.01 \\
0.00\end{array}$ & $\begin{array}{l}2.24 \\
1.72 \\
0.02 \\
0.00 \\
0.02 \\
0.81 \\
0.18 \\
0.00 \\
0.00\end{array}$ & $\begin{array}{l}2.37 \\
1.54 \\
0.05 \\
0.00 \\
0.07 \\
0.68 \\
0.29 \\
0.00 \\
0.00\end{array}$ & $\begin{array}{l}2.17 \\
1.80 \\
0.01 \\
0.00 \\
0.01 \\
0.87 \\
0.15 \\
0.00 \\
0.00\end{array}$ & $\begin{array}{l}2.23 \\
1.72 \\
0.01 \\
0.00 \\
0.02 \\
0.83 \\
0.17 \\
0.00 \\
0.00\end{array}$ & $\begin{array}{l}2.25 \\
1.73 \\
0.03 \\
0.00 \\
0.04 \\
0.76 \\
0.17 \\
0.01 \\
0.00\end{array}$ & $\begin{array}{l}2.27 \\
1.69 \\
0.02 \\
0.00 \\
0.02 \\
0.77 \\
0.24 \\
0.00 \\
0.00\end{array}$ & $\begin{array}{l}2.29 \\
1.66 \\
0.02 \\
0.00 \\
0.02 \\
0.78 \\
0.23 \\
0.00 \\
0.00\end{array}$ & $\begin{array}{l}2.28 \\
1.68 \\
0.02 \\
0.00 \\
0.02 \\
0.75 \\
0.27 \\
0.00 \\
0.00\end{array}$ & $\begin{array}{l}2.30 \\
1.67 \\
0.01 \\
0.00 \\
0.01 \\
0.76 \\
0.25 \\
0.00 \\
0.00\end{array}$ & $\begin{array}{l}2.18 \\
1.80 \\
0.00 \\
0.00 \\
0.01 \\
0.85 \\
0.15 \\
0.00 \\
0.00\end{array}$ & $\begin{array}{l}2.14 \\
1.84 \\
0.01 \\
0.00 \\
0.01 \\
0.87 \\
0.12 \\
0.00 \\
0.00\end{array}$ \\
\hline $\begin{array}{l}\mathrm{Cr} \\
\text { Total }\end{array}$ & $\begin{array}{l}0.00 \\
3.00\end{array}$ & $\begin{array}{l}0.00 \\
2.99\end{array}$ & 5.00 & 4.98 & 4.99 & 5.00 & 5.01 & 4.99 & 4.98 & 5.01 & 5.00 & 5.01 & 4.99 & 5.00 & 5.00 \\
\hline
\end{tabular}

and their overall chemistry indicate that smectite is the predominant phyllosilicate.

We distinguish seven types of clay minerals, based on their optical features. These features, together with their mode of occurrence, relative abundances, and main chemical characteristics are summarized in Table 2.

The chemical composition of the clay minerals is variable, with variations in major oxide content distinguishing seven different types (Figs. 5, 6; Tables 3-9), which can be gathered into two main groups (Fig. 5). The first group is $\mathrm{K}$-poor and has variable $\mathrm{FeO} / \mathrm{FeO}+\mathrm{MgO}$ ratios, whereas the second group is $\mathrm{K}$-rich and shows a relatively constant $(=0.83) \mathrm{FeO} / \mathrm{FeO}+\mathrm{MgO}$ ratio. Other compositions are mixtures of these two main types. The number of cations in octahedral sites $(=\mathrm{NBO})$ reported vs. $\mathrm{K}_{2} \mathrm{O}$ or $\mathrm{MgO}$ clearly distinguishes the various types (Fig. 7).

Types 1 (pale brown) and 2 (colorless to very pale green) clearly have a chemical composition of saponite (high $\mathrm{MgO}, \mathrm{SiO}_{2}$, and $\mathrm{NBO}$, low $\mathrm{FeO}_{t}$; Tables 3,4 ). They plot near the saponite end member (Figs. 7A, B). Whereas type 1 phyllosilicate plots in the saponite field of Velde's classification, type 2 plots between the saponite and the chlorite field (Fig. 8). X-ray diffraction of the clay minerals composing veins, where enough material is available, shows only the occurrence of trioctahedral smectite.

Types 3 (bright green), 4 (dark green), and 5 (yellow green) contain high concentrations of $\mathrm{K}_{2} \mathrm{O}$ (Tables 5-7).

Types 3 and 4 have relatively similar chemical compositions, with $\mathrm{K}_{2} \mathrm{O}, \mathrm{Al}_{2} \mathrm{O}_{3}$, and $\mathrm{FeO}_{1}$ ranging from $5 \%$ to $8 \%, 1 \%$ to $4 \%$, and $23 \%$ to $26 \%$, respectively. Both types are thought to be mixtures of celadonite and nontronite (Fig. 7B), whereas type 5 is probably a mixture of celadonite-nontronite and saponite, as suggested by the lower $\mathrm{K}_{2} \mathrm{O}$ ( $2 \%$ to $4 \%$ ), higher $\mathrm{Al}_{2} \mathrm{O}_{3}$ (3\% to $6 \%$ ), and higher $\mathrm{MgO}$ (4\% to $15 \%$; Fig. 7A). The wide range of composition of the type 5 phyllosilicate is in agreement with the idea of a mixture. These three types are also well distinguished in Velde's classification (Fig. 8).

Type 6 (blue-green) occurs as fibers or well-crystallized aggregates intergrown with saponite, in the groundmass, and has been observed only in coarse-grained basalts from massive flows. In plane light, it is blue-green and pleochroic. It exhibits a dark blue abnormal interference color, or a yellowish, first-order color. It is distinguished by the highest $\mathrm{Al}_{2} \mathrm{O}_{3}(7 \%-9 \%)$ and lowest $\mathrm{SiO}_{2}(33 \%-40 \%)$ of all phyllosilicates from Hole $896 \mathrm{~A}$, and is probably a mixed-layer chlorite-saponite (Table 8; Figs. 8,9). The percentage $(X)$ of pure chlorite in this mixed-layer was calculated using Wise's method described in Bettison and Schiffman (1988) and Bevins et al. (1991). Structural formulas and corresponding $X$ values are presented in Table $8 . X$ ranges from 0.6 to 0.8 , indicating a relatively high proportion of chlorite layers. The importance of the chloritic component in type 6 phyllosilicates is also evidenced in the Robinson et al.'s (1993) diagram (Fig. 9). Type 7 (orange yellow) has a composition of Fe-rich saponite or mixture of saponite and Fe-oxides (Table 9; Fig. 7).

\section{Fe-hydroxides and Mixtures of Fe-hydroxides and Clay Minerals (Iddingsites)}

Mixtures of Fe-hydroxides and clay minerals have been named type 8 . They are represented by subtypes $8 \mathrm{a}$ and $8 \mathrm{~b}$. Subtype $8 \mathrm{a}$ is presumably a complex mixture of saponite, celadonite and iron oxyhydroxides (Table 10; Figs. 8, 9). Subtype 8 b does not contain much $\mathrm{K}_{2} \mathrm{O}(<1.5 \%)$ and has variable but high $\mathrm{FeO}_{\text {, content }}(24 \%-72 \%$; Table 10). These heterogeneous compositions are typical of mixtures of Fe oxy-hydroxides and saponite. Pure goethite has also been identified optically.

As a conclusion, most phyllosilicates from Hole 896A are saponites. Common celadonite, celadonite-nontronite mixtures, celadonite-nontronite-saponite mixtures, and saponite-celadonite-iron oxides mixtures also occur. These four types of celadonite-bearing minerals are probably similar to the "celadonites" described by Andrews (1977) in Leg 37 basalts, to the protoceladonites mentioned by Mével (1979) and Donnelly et al. (1979) in the Legs 51-53 basalts, to the "mixtures or interlayered minerals of varying proportions of saponite with Fe-mica" studied by Böhlke et al. (1980) in basalts from Hole 396B, and to the celadonite occurring in the upper part (UPAZ) of Hole 504B (Honnorez et al., 1983).

\section{Calcium Carbonates}

Calcite and aragonite were optically distinguished from one another by their conoscopic figure or by the extinction angle. X-ray dif- 
Table 1 (continued).

\begin{tabular}{|c|c|c|c|c|c|c|c|c|c|c|c|c|}
\hline $\begin{array}{l}\text { Core, section: } \\
\text { Interval (cm): } \\
\text { Piece no. } \\
\text { Deph (mbsf): } \\
\text { Mineral: } \\
\text { Analysis no.: }\end{array}$ & $\begin{array}{c}2 \mid \mathrm{R}-1 \\
84-9 \mid \\
14 \\
373.7 \\
\mathrm{Cr}-\mathrm{spin} \\
\mathrm{M} 23\end{array}$ & $\begin{array}{c}2 \mid R-1 \\
84-91 \\
14 \\
373.7 \\
\text { Cr-spin } \\
\text { M38 }\end{array}$ & $\begin{array}{c}2 \text { IR }-2 \\
33-38 \\
4 \\
374.80 \\
\text { Cr-spin } \\
\text { M135 }\end{array}$ & $\begin{array}{c}23 \mathrm{R}-2 \\
0-6 \\
1 \mathrm{~A} \\
393.6 \\
\text { Cr-spin } \\
\text { M56 }\end{array}$ & $\begin{array}{c}23 \mathrm{R}-2 \\
0-6 \\
1 \mathrm{~A} \\
393.6 \\
\text { Cr-spin } \\
\text { M57 }\end{array}$ & $\begin{array}{l}\text { Core, section: } \\
\text { Interval (cm): } \\
\text { Piece no.: } \\
\text { Depth (mbsf): } \\
\text { Mineral: } \\
\text { Analysis no.: }\end{array}$ & $\begin{array}{c}17 \mathrm{R}-4 \\
15-20 \\
2 \mathrm{C}\end{array}$ & $\begin{array}{c}23 \mathrm{R}-2 \\
0-6 \\
1 \mathrm{~A} \\
393.6 \\
\text { Cpx m } \\
\text { M52 }\end{array}$ & $\begin{array}{c}24 R-1 \\
88-89 \\
6 \\
402.7 \\
\text { Cpxp } \\
\text { MI19 } \\
\end{array}$ & $\begin{array}{c}25 \mathrm{R}-3 \\
30-34 \\
5 \\
414.4 \\
\text { Cpx m } \\
\text { M91 }\end{array}$ & $\begin{array}{c}17 \mathrm{R}-3 \\
43-45 \\
4 \\
346.8 \\
\text { Ti-mag } \\
\text { M55 }\end{array}$ & $\begin{array}{c}24 R-1 \\
88-92 \\
6 \\
402.7 \\
\text { Ti-mag } \\
\text { M163 }\end{array}$ \\
\hline 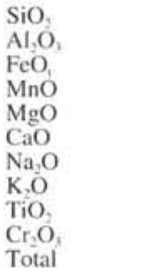 & $\begin{array}{r}0.26 \\
35.89 \\
16.18 \\
0.24 \\
16.49 \\
0.12 \\
0.00 \\
0.02 \\
0.30 \\
30.47 \\
99.97\end{array}$ & $\begin{array}{r}0.31 \\
22.71 \\
17.29 \\
0.17 \\
14.22 \\
0.06 \\
0.00 \\
0.01 \\
0.50 \\
43.16 \\
99.44\end{array}$ & $\begin{array}{r}0.29 \\
26.30 \\
18.07 \\
0.21 \\
15.22 \\
0.00 \\
0.00 \\
0.00 \\
0.54 \\
38.31 \\
98.94\end{array}$ & $\begin{array}{r}0.22 \\
27.41 \\
17.27 \\
0.29 \\
14.54 \\
0.08 \\
0.00 \\
0.00 \\
0.26 \\
39.66 \\
99.73\end{array}$ & $\begin{array}{r}0.21 \\
29.24 \\
17.51 \\
0.21 \\
14.95 \\
0.08 \\
0.00 \\
0.00 \\
0.26 \\
36.77 \\
99.24\end{array}$ & $\begin{array}{l}\mathrm{SiO}_{3} \\
\mathrm{Al}_{3} \mathrm{O}_{3} \\
\mathrm{FeO}_{4} \\
\mathrm{MnO} \\
\mathrm{MgO} \\
\mathrm{CaO} \\
\mathrm{Na}_{2} \mathrm{O} \\
\mathrm{K} \mathrm{O}^{2} \\
\mathrm{TiO}_{2} \\
\mathrm{Cr}_{3} \mathrm{O}_{2} \\
\mathrm{Total}^{2}\end{array}$ & $\begin{array}{r}49.83 \\
4.33 \\
9.64 \\
0.02 \\
15.91 \\
18.93 \\
0.21 \\
0.00 \\
0.35 \\
1.46 \\
100.68\end{array}$ & $\begin{array}{r}50.06 \\
4.97 \\
11.94 \\
0.30 \\
13.87 \\
19.03 \\
0.26 \\
0.00 \\
0.54 \\
0.03 \\
100.99\end{array}$ & $\begin{array}{r}51.77 \\
2.85 \\
8.12 \\
0.29 \\
16.69 \\
19.55 \\
0.26 \\
0.00 \\
0.44 \\
0.11 \\
100.07\end{array}$ & $\begin{array}{r}49.25 \\
3.97 \\
14.97 \\
0.33 \\
10.08 \\
18.37 \\
0.34 \\
0.01 \\
1.82 \\
0.00 \\
99.14\end{array}$ & $\begin{array}{r}0.37 \\
2.86 \\
75.36 \\
0.53 \\
1.40 \\
0.09 \\
0.02 \\
0.04 \\
12.73 \\
0.03 \\
93.41\end{array}$ & $\begin{array}{r}0.43 \\
1.28 \\
71.05 \\
0.94 \\
0.27 \\
0.00 \\
0.00 \\
0.00 \\
20.29 \\
0.00 \\
94.24\end{array}$ \\
\hline $\begin{array}{l}\mathrm{Si} \\
\mathrm{Al} \\
\mathrm{Fe} \\
\mathrm{Mn} \\
\mathrm{Mg} \\
\mathrm{Ca} \\
\mathrm{Na} \\
\mathrm{K} \\
\mathrm{Ti} \\
\mathrm{Cr} \\
\mathrm{Tr}\end{array}$ & $\begin{array}{r}0.06 \\
9.74 \\
3.12 \\
0.05 \\
5.66 \\
0.03 \\
0.00 \\
0.01 \\
0.05 \\
5.55 \\
24.25\end{array}$ & $\begin{array}{r}0.08 \\
6.66 \\
3.60 \\
0.04 \\
5.27 \\
0.02 \\
0.00 \\
0.00 \\
0.09 \\
8.49 \\
24.25\end{array}$ & $\begin{array}{r}0.07 \\
7.55 \\
3.68 \\
0.04 \\
5.53 \\
0.00 \\
0.00 \\
0.00 \\
0.10 \\
7.38 \\
24.36\end{array}$ & $\begin{array}{r}0.05 \\
7.79 \\
3.48 \\
0.06 \\
5.22 \\
0.02 \\
0.00 \\
0.00 \\
0.05 \\
7.56 \\
24.23\end{array}$ & $\begin{array}{l}0.05 \\
8.27 \\
3.52 \\
0.04 \\
5.35 \\
0.02 \\
0.00 \\
0.00 \\
0.05 \\
6.98 \\
24.28\end{array}$ & $\begin{array}{l}\mathrm{Si} \\
\mathrm{Al}^{\mathrm{Iv}} \\
\mathrm{Al}^{\mathrm{lvt}} \\
\mathrm{Fe}^{2 *} \\
\mathrm{Fe}^{\mathrm{j}} \\
\mathrm{Mn} \\
\mathrm{Mg} \\
\mathrm{Ca} \\
\mathrm{Na} \\
\mathrm{K} \\
\mathrm{Ti} \\
\mathrm{Cr} \\
\text { Total }\end{array}$ & $\begin{array}{l}1.83 \\
0.17 \\
0.02 \\
0.19 \\
0.10 \\
0.00 \\
0.87 \\
0.75 \\
0.02 \\
0.00 \\
0.01 \\
0.04 \\
4.00\end{array}$ & $\begin{array}{l}1.85 \\
0.15 \\
0.07 \\
0.30 \\
0.07 \\
0.01 \\
0.77 \\
0.75 \\
0.02 \\
0.00 \\
0.02 \\
0.00 \\
4.00\end{array}$ & $\begin{array}{l}1.90 \\
0.10 \\
0.03 \\
0.19 \\
0.07 \\
0.01 \\
0.91 \\
0.77 \\
0.02 \\
0.00 \\
0.01 \\
0.00 \\
4.00\end{array}$ & $\begin{array}{l}1.90 \\
0.10 \\
0.09 \\
0.48 \\
0.00 \\
0.01 \\
0.58 \\
0.76 \\
0.03 \\
0.00 \\
0.05 \\
0.00 \\
4.00\end{array}$ & $\begin{array}{r}0.90 \\
0.81 \\
0.48 \\
2.26 \\
0.10 \\
0.04 \\
0.05 \\
10.35 \\
0.02 \\
19.06\end{array}$ & $\begin{array}{r}0.73 \\
0.65 \\
0.69 \\
0.34 \\
0.00 \\
0.00 \\
0.00 \\
13.28 \\
0.00 \\
17.37\end{array}$ \\
\hline $\begin{array}{l}\text { Fo } \\
\text { Fa }\end{array}$ & & & & & & $\begin{array}{l}\text { Wo } \\
\text { En } \\
\text { Fs }\end{array}$ & $\begin{array}{l}41.14 \\
48.10 \\
10.76\end{array}$ & $\begin{array}{l}41.22 \\
41.79 \\
16.99\end{array}$ & $\begin{array}{l}40.99 \\
48.68 \\
10.33\end{array}$ & $\begin{array}{l}39.94 \\
30.49 \\
29.58\end{array}$ & $\begin{array}{l}35.80 \\
42.11\end{array}$ & $\begin{array}{l}59.99 \\
61.84\end{array}$ \\
\hline
\end{tabular}

Note: Formulas are calculated on the basis of 4 oxygens for olivine, 6 oxygens for clinopyroxene, 8 oxygens for plagioclase, 32 oxygens for titanomagnetite and $\mathrm{Cr}$-spinel. Plag $\mathrm{m}=$ plagioclase microcrystal, Plag $\mathrm{p}=$ plagioclase phenocrystal, Ti-mag $=$ titanomagnetite. $\mathrm{Cr}$-spin $=$ chromium spinel, Cpx $\mathrm{m}=$ clinopyroxene microcrystal, and $\mathrm{Cpx}$ p = clinopyroxene phenocrystal.

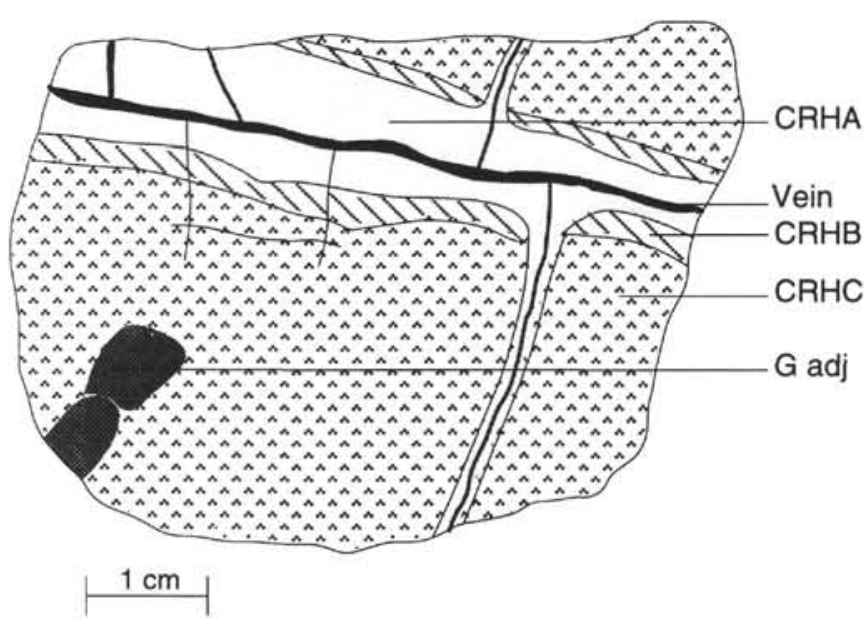

Figure 2. Sketch of the various zones of a compound red halo, Sample 148896A-17R-3, 43-49 cm. Piece 5B. CRHA = dark red-brown halo, CRHB = bright red halo, $\mathrm{CRHC}=$ yellowish halo, $\mathrm{G}$ adj $=$ gray adjacent basalt, vein = saponite and $\mathrm{Ca}$-carbonate vein.

fraction was also used to distinguish calcite from aragonite. Analyzed Ca-carbonates are pure, except one $\mathrm{MgO}$-bearing calcite $(2.3 \%$ $\mathrm{MgO}$ ) filling a vesicle (Table 11).

\section{Zeolites}

Phillipsite (Table 12) occurs as colorless prisms in veins and as fibroradiating crystals in hyaloclastites and pillow breccias. Some of the analyzed phillipsites are Ca-rich, which is exceptional for oceanic phillipsites. The occurrence of analcite and natrolite, which were tentatively identified during Leg 148, could not be confirmed in this study.

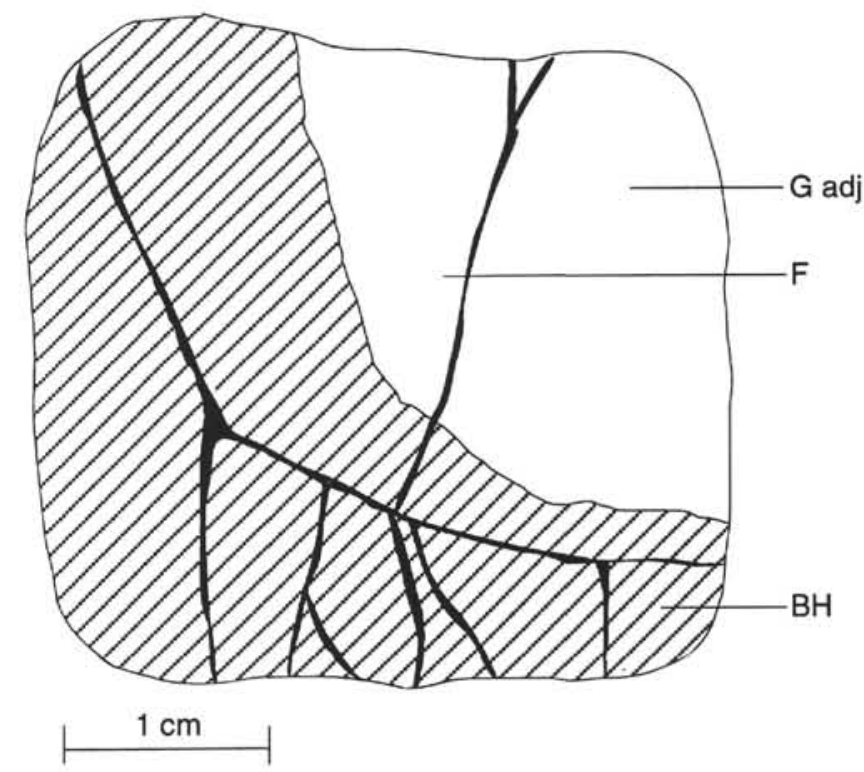

Figure 3. Sketch of a black halo $(\mathrm{BH})$ and its gray adjacent basalt ( $\mathrm{G}$ adj), Sample 148-896A-17R-3, 43-49 cm, Piece 4. F = open fracture.

A massive zeolite has been observed as glass replacement near fibrous saponite and brown isotropic palagonite in Sample 148-896A28R-1, 107-108 cm (Piece 18B), which has the composition of chabazite (Table 12). Nevertheless, this identification could not be confirmed by XRD because of the small amount of material present.

\section{Pyrite}

Pyrite occurs in vesicles and veinlets, with saponite (types 1 and 2). Chalcopyrite containing exsolutions of sphalerite has been identi- 


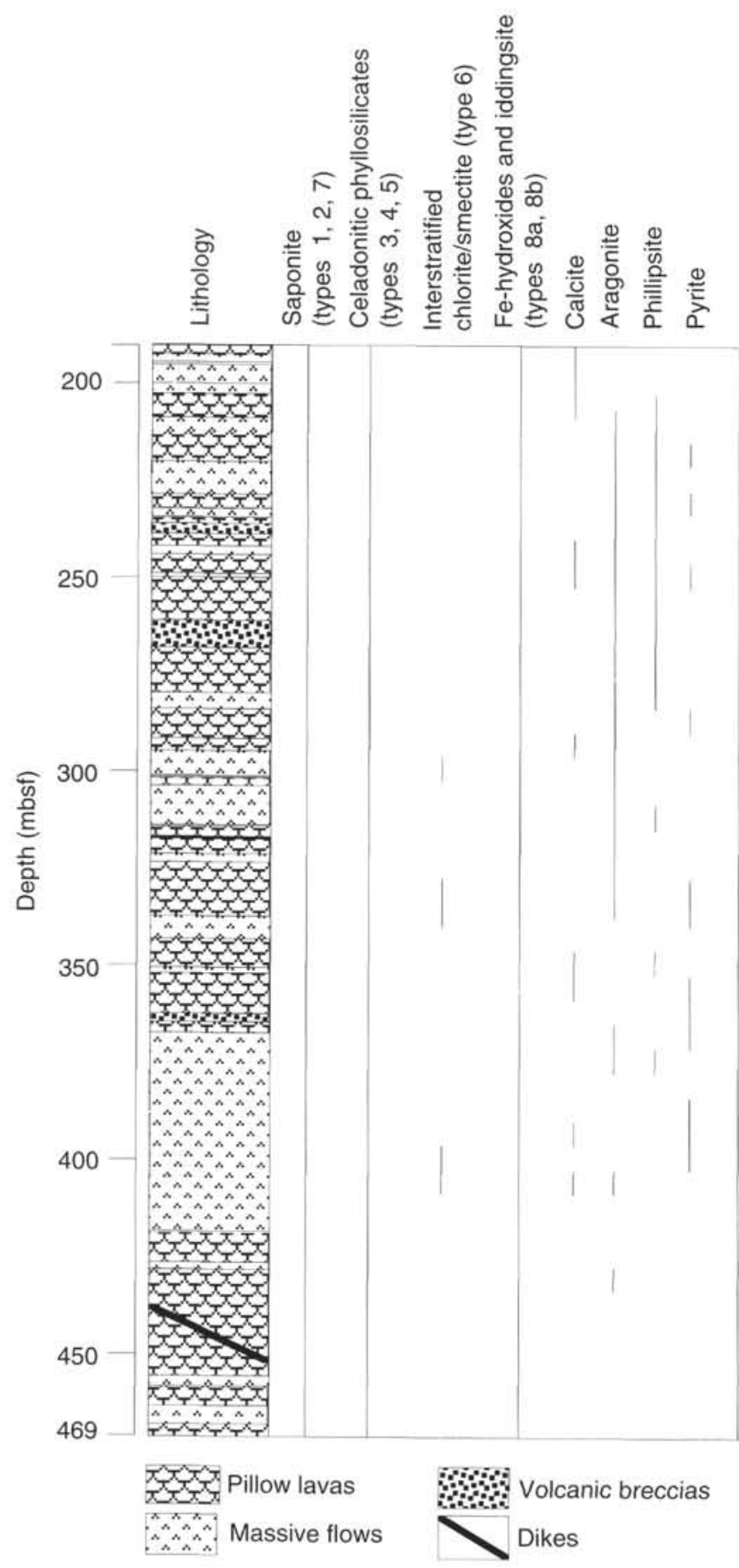

Figure 4. Diagram showing the occurrence of alteration minerals with depth in Hole 896A, on the basis of this study and shipboard thin-section and X-ray diffraction studies.

fied in two samples (Samples 148-896A-21R-2, 66-69 cm, Piece 8; and 24R-1, 88-92 cm, Piece 6).

\section{REPLACEMENT OF GLASS}

Fresh glass has been recovered frequently from Hole $896 \mathrm{~A}$ and rims the pillow lavas. The glassy pillow rims are commonly crisscrossed by thin veinlets $(0.01$ to $3 \mathrm{~mm})$, along which the glass is replaced by a brownish fibropalagonite or saponite.
Although the purpose of this paper does not include the study of hyaloclastites and breccias, some analyses of glass and palagonite replacing glass have been made (Table 13). None of the "palagonite" analyses correspond to a pure mineral. All are mixtures of saponite, zeolite and sometimes glass. The replacement of glass by "palagonite" involves a $\mathrm{CaO}$ and $\mathrm{SiO}_{2}$ decrease and a $\mathrm{MgO}$ increase (Fig. 10; Table 13).

\section{REPLACEMENT OF MAGMATIC MINERALS AND PRIMARY VOID FILLING}

The four transparent magmatic minerals (i.e., olivine, plagioclase, clinopyroxene and $\mathrm{Cr}$-spinel) are variously affected by alteration. $\mathrm{Cr}$ spinel is always fresh. Olivine is the magmatic mineral which is the most sensitive to alteration in oceanic basalts. In Hole 896A basalts, olivine is partly or completely replaced by saponite (types 1,2 ) in the gray basalt adjacent to alteration halos, whereas it is partly or completely replaced by iddingsite (type 8 ) at the rim and one or several types of clay minerals (i.e., celadonitic minerals and saponite) in the cores (Fig. 11) in the various oxidized halos ( $\mathrm{RH}, \mathrm{CRH}$, and $\mathrm{BrH}$ ) and black halos (Tables 14-17). The more common relationship between oxidation and olivine breakdown is the situation in which relict cores of fresh olivine are present within the gray adjacent basalt, and that olivine within the oxidized halos is completely replaced by iddingsite and rarely aragonite.

Plagioclase is generally fresh. However, when in contact with saponite veins, plagioclase is slightly to intensively altered to saponite (types 1,2).

Clinopyroxene phenocrysts and microphenocrysts are not visibly altered. Clinopyroxene plumoses occurring in the groundmass of fine-grained basalts are commonly replaced (or stained?) by Feoxyhydroxides in alteration halos (Tables 14-16).

All the titanomagnetite is apparently replaced by titanomaghemite, but the small size of the opaque grains makes this determination remain questionable (Honnorez et al., this volume).

The fillings of vesicles, vugs, and miarolitic voids are commonly zoned, with iddingsite nearest the void walls in alteration halos (Tables $14-17$ ). In the gray adjacent basalt, these primary voids are filled with saponite \pm Ca-carbonates.

\section{MINERALOGICAL COMPOSITION OF THE ALTERATION HALOS}

The secondary minerals occurring in the various types of alteration halos are summarized in Tables 14-17 together with their modes of occurrence. The gray basalt adjacent to any type of alteration halo is characterized by the presence of saponite and the lack of $\mathrm{K}$ - and $\mathrm{Fe}^{3+}$-rich minerals. However, all the variously colored alteration halos contain iddingsite and saponite. Brown halos, black halos, and Zone A of composite red halos are characterized by the presence of celadonitic minerals, together with iddingsite and saponite.

\section{VEINS}

The mineralogical composition and crosscutting relationships of veins are studied in detail by Tartarotti et al. (this volume). A brief summary of our own observations is given below. The temporal depositional sequence of secondary minerals in open fractures from many samples was probably as follows: (1) iddingsite (types $8 \mathrm{a}$ and 8 b) and/or celadonitic minerals (type 4); (2) pale green saponite (type 2 ); and (3) carbonates. When phillipsite is present, the following sequence is observed: (1) celadonitic minerals (types $3,4,5$ ?); (2) phillipsite; (3) pale brown saponite (type 2); (4) calcite; and (5) calcite or aragonite. Alternatively, the following sequence has been found: (1) 
Table 2. Main characteristics of phyllosilicates from Hole 896A.

\begin{tabular}{|c|c|c|c|c|c|c|c|c|}
\hline Type & Shape & Pleochroism & $\begin{array}{l}\text { Color with crossed } \\
\text { polars }\end{array}$ & Mode of occurrence & Type of rock & Abundance & $\begin{array}{l}\text { Dominant chemical } \\
\text { feature }\end{array}$ & Mineral \\
\hline I (pale brown) & $\begin{array}{l}\text { Fibers or } \\
\text { granules }\end{array}$ & Nonexistent & Gray (first order) & $\begin{array}{l}\text { Olivine, vesicle, } \\
\text { vein, interstitial }\end{array}$ & All types & $\begin{array}{l}\text { Very } \\
\text { common }\end{array}$ & $\begin{array}{l}\text { High } \mathrm{MgO} \text {, low } \\
\mathrm{FeO}\end{array}$ & Saponite \\
\hline 2 (very pale green) & Fibers & $\begin{array}{c}\text { Nonexistent } \\
\text { or slight }\end{array}$ & $\begin{array}{l}\text { Gray to orange } \\
\text { (first order) }\end{array}$ & $\begin{array}{l}\text { Plagioclase, } \\
\text { olivine, vesicle, } \\
\text { vein, interstitial }\end{array}$ & All types & $\begin{array}{l}\text { Very } \\
\text { common }\end{array}$ & $\begin{array}{l}\text { High } \mathrm{MgO} \text {, low } \\
\mathrm{FeO}_{1}\end{array}$ & Saponite \\
\hline 3 (bright green) & $\begin{array}{l}\text { Small } \\
\text { slabs }\end{array}$ & Medium & Second order & $\begin{array}{l}\text { Olivine rim, vesicle } \\
\text { rim, vein }\end{array}$ & $\begin{array}{l}\text { CRHA, BH, } \\
\text { BrH }\end{array}$ & Rare & $\begin{array}{l}\text { High } \mathrm{K}_{2} \mathrm{O} \text {, med } \\
\mathrm{FeO}_{1}\end{array}$ & Celadonite \\
\hline 4 (dark green) & $\begin{array}{l}\text { Small } \\
\text { fibers }\end{array}$ & Nonexistent & $\begin{array}{l}\text { Abnormal dark } \\
\text { green }\end{array}$ & $\begin{array}{l}\text { Olivine rim, vesicle, } \\
\text { interstitial. vein }\end{array}$ & $\begin{array}{l}\text { CRHA, BH, } \\
\text { BrH }\end{array}$ & Common & $\begin{array}{l}\mathrm{Med} \mathrm{K}, \mathrm{O} \text {, med } \\
\mathrm{FeO}_{4}\end{array}$ & $\begin{array}{l}\text { Celadonite or mixture } \\
\text { celadonite-saponite }\end{array}$ \\
\hline 5 (yellow green) & $\begin{array}{l}\text { Radiating } \\
\text { fibers }\end{array}$ & Nonexistent & $\begin{array}{l}\text { Abnormal yellow } \\
\text { green }\end{array}$ & $\begin{array}{l}\text { (Olivine), vesicle, } \\
\text { interstitial, vein }\end{array}$ & $\begin{array}{l}\mathrm{BrH}, \mathrm{CRHA} \text {. } \\
\mathrm{BH}\end{array}$ & Common & $\begin{array}{l}\mathrm{Med} \mathrm{K}_{2} \mathrm{O} \text {, med } \\
\mathrm{FeO}\end{array}$ & $\begin{array}{l}\text { Celadonite-saponite or } \\
\text { celadonite-nontronite mixture }\end{array}$ \\
\hline 6 (blue green) & Slabs & $\begin{array}{l}\text { Medium to } \\
\text { strong }\end{array}$ & $\begin{array}{l}\text { Abnormal bluish } \\
\text { gray }\end{array}$ & Vesicle, interstitial & $\begin{array}{l}\text { RH, CRHB. } \\
\text { CRHC }\end{array}$ & Rare & $\begin{array}{l}\text { Low } \mathrm{SiO}_{2} \text {, high } \\
\mathrm{Al}_{2} \mathrm{O}_{4}\end{array}$ & Interlayered chlorite-smectite \\
\hline 7 (orange yellow) & $\begin{array}{l}\text { Small } \\
\text { fibers }\end{array}$ & Nonexistent & Abnormal orange & $\begin{array}{l}\text { Olivine rim, vesicle. } \\
\text { interstitial }\end{array}$ & CRHB, CRHC & Common & $\begin{array}{l}\text { High } \mathrm{FeO}_{4}, \text { low } \\
\mathrm{K}, \mathrm{O}\end{array}$ & $\begin{array}{l}\text { Fe-saponite or mixture saponite- } \\
\text { Fe oxide }\end{array}$ \\
\hline $8 \mathrm{a}$ (orange yellow) & $\begin{array}{l}\text { Small } \\
\text { fibers }\end{array}$ & Nonexistent & Abnormal brown & $\begin{array}{l}\text { Olivine rim, vesicle, } \\
\text { interstitial, vein }\end{array}$ & CRHB & Common & $\begin{array}{l}\text { Very high } \mathrm{FeO}_{i} \text {. } \\
\text { med } \mathrm{K}, \mathrm{O}\end{array}$ & $\begin{array}{l}\text { Iddingsite containing much } \\
\text { celadonite }\end{array}$ \\
\hline $8 \mathrm{~b}$ (orange to red) & Granules & Nonexistent & Abnormal brown & $\begin{array}{l}\text { Olivine rim, vesicle, } \\
\text { interstitial, vein }\end{array}$ & $\begin{array}{l}\text { CRHA, CRHB, } \\
\text { CRHC }\end{array}$ & Common & $\begin{array}{l}\text { Very high } \mathrm{FeO}_{1} \text {. } \\
\text { low } \mathrm{K}_{2} \mathrm{O}\end{array}$ & $\begin{array}{l}\text { Iddingsite containing few } \\
\text { celadonite }\end{array}$ \\
\hline
\end{tabular}

Notes: $\mathrm{BH}=$ black halo, $\mathrm{BrH}=$ brown halo, $\mathrm{RH}=$ simple red halo, $\mathrm{CRHA}=\mathrm{Zone} \mathrm{A}$ of composite red halo. $\mathrm{CRHB}=\mathrm{Zone} \mathrm{B}$ of composite red halo. and $\mathrm{CRHC}=\mathrm{Zone} \mathrm{C}$ of composite red halo.

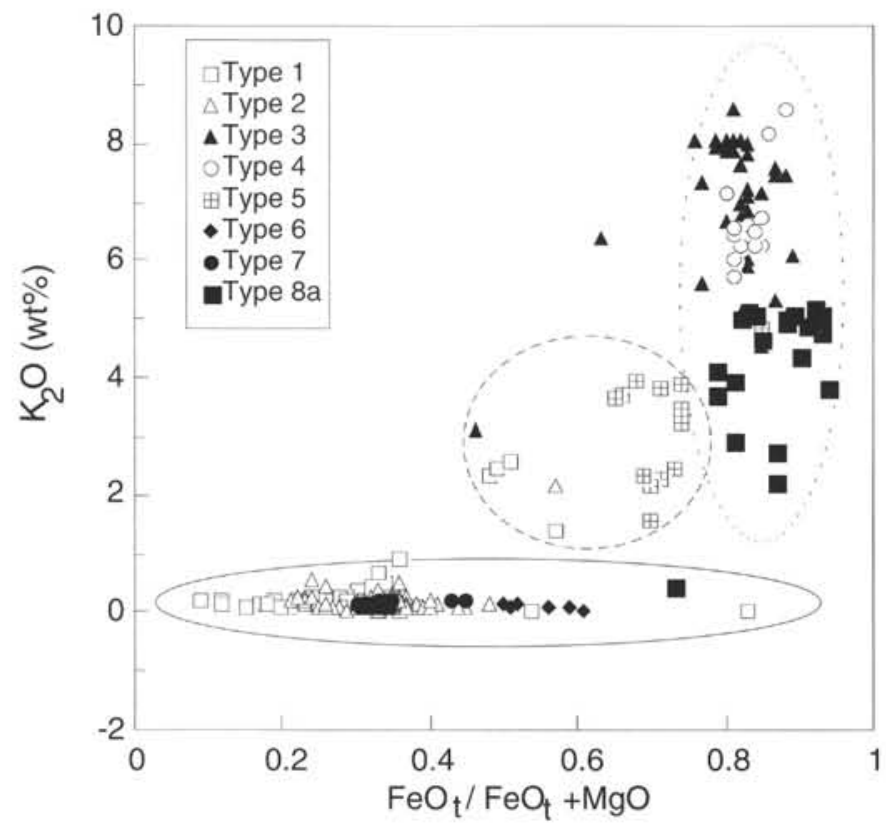

Figure 5. $\mathrm{K}_{2} \mathrm{O}$ content vs. $\mathrm{FeO}_{1} / \mathrm{FeO}_{4}+\mathrm{MgO}$ ratio of clay minerals and iddingsite from Hole 896A. Types are described in the text and Table 2. Solid line $=$ field of $\mathrm{K}_{2} \mathrm{O}$-poor and variable $\mathrm{FeO}_{1} / \mathrm{FeO}_{1}+\mathrm{MgO}$ ratio phyllosilicates (trioctahedral smectites, sensu lato): dotted line $=$ field of $\mathrm{K}_{2} \mathrm{O}$-rich and constant $\mathrm{FeO}_{1} / \mathrm{FeO}_{1}+\mathrm{MgO}$ ratio phyllosilicates (celadonite-bearing minerals); dashed line $=$ field of mixtures between the two types of phyllosilicates mentioned.

iddingsite; (2) celadonitic minerals; (3) saponite (types 1 or 2); (3) phillipsite; (4) carbonates. In some other samples, the pale green saponite can be interpreted either as earlier or later than calcite. Several generations of saponite probably occur, but this must be confirmed by a more detailed study of veins, hyaloclastites and breccias.

\section{BULK-ROCK GEOCHEMISTRY}

To document the changes in bulk-rock chemistry which took place during seawater-basalt interactions, we performed 42 chemical

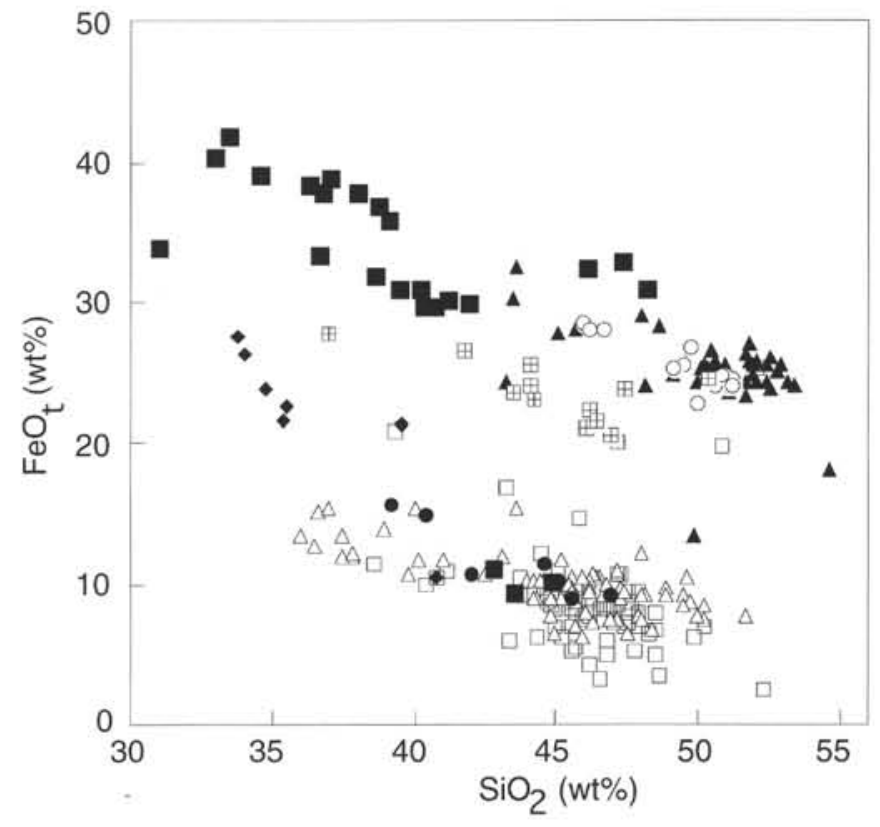

Figure 6. $\mathrm{FeO}_{1}$ content vs. $\mathrm{SiO}_{2}$ content of clay minerals and iddingsite from Hole 896 A (symbols as in Fig. 5).

analyses of basalts from Hole 896A. The various types of alteration halos from 15 samples were separated by sawing the halos off the rock sample. Six pairs, seven triplets, and two quadruplets were analyzed. In compound red halos, the thin halo CRHB could not always be separated from adjacent halos CRHA and CRHC. Furthermore, the freshest, unoxidized, gray part ( $\mathrm{G}$ adj) of these halos was commonly missing. Major and traces elements were analyzed in each part (Table 18).

The average composition of 158 electron microprobe analyses of fresh glass riming pillows from Hole $896 \mathrm{~A}$ (Fisk et al., this volume) and the analysis of glass of this study (Table 12) has been compared to both alteration halos and gray adjacent basalts.

Basalts recovered in Hole $896 \mathrm{~A}$ are oxidized to various extents, as seen in Figure 12.

In the compound red halos, the oxidation ratio $\left(=\mathrm{Fe}_{2} \mathrm{O}_{3} / \mathrm{Fe}_{2} \mathrm{O}_{3}+\right.$ $\mathrm{FeO}$ ) and $\mathrm{Fe}_{2} \mathrm{O}_{31}$ content decrease from the halo in contact with the 
Table 3. Representative analysis of type 1 phyllosilicate (saponite), Hole 896A.

\begin{tabular}{|c|c|c|c|c|c|c|c|c|c|c|c|c|c|c|c|c|c|c|}
\hline Core, section: & $4 R-1$ & $17 R-3$ & $17 R-3$ & $17 \mathrm{R}-3$ & 17R-3 & $17 R-3$ & $24 \mathrm{R}-1$ & $24 \mathrm{R}-1$ & $24 R-1$ & $24 R-1$ & $25 \mathrm{R}-3$ & $25 R-3$ & $25 R-3$ & $25 \mathrm{R}-3$ & $25 R-3$ & $25 \mathrm{R}-3$ & $28 \mathrm{R}-1$ & 28R-1 \\
\hline Interval $(\mathrm{cm})$ : & $37-44$ & $43-45$ & $43-45$ & $43-45$ & $43-45$ & $43-45$ & $88-92$ & $88-92$ & $88-92$ & $88-92$ & $30-34$ & $30-34$ & $30-34$ & $30-34$ & $30-34$ & $30-34$ & $107-108$ & $107-108$ \\
\hline Piece no.: & 8 & 4 & 4 & 4 & 4 & 4 & 6 & 6 & 6 & 6 & 5 & 5 & 5 & 5 & 5 & 5 & $18 \mathrm{~B}$ & $18 \mathrm{~B}$ \\
\hline Depth (mbsf): & 219.3 & 346.8 & 346.8 & 346.8 & 346.8 & 346.8 & 402.7 & 402.7 & 402.7 & 402.7 & 414.4 & 414.4 & 414.4 & 414.4 & 414.4 & 414.4 & 440.9 & 440.9 \\
\hline Rock type: & $\mathrm{G}$ adj & $\mathrm{BH}$ & $\mathrm{BH}$ & $\mathbf{G}$ adj & $\mathrm{G}$ adj & $\mathbf{G}$ adj & $\mathrm{G}$ adj & $\mathrm{G}$ adj & G adj & CRHB,C & CRHA & CRHA & CRHA & CRHA & CRHA & CRHA & Glass & Glass \\
\hline & Ves c & Oliv c & Oliv c & Oliv $t$ & Oliv t & Oliv t & Inter & Inter & Oliv t & Oliv t & Glass & Glass & Glass & Glass & Glass & Vesicle & Vein & Vein \\
\hline Analysis no.: & M106 & M50 & M52 & M76 & M77 & M83 & M147 & M148 & M157 & M166 & & & M85 & M86 & M87 & M99 & M77 & M78 \\
\hline $\mathrm{SiO}_{2}$ & 47.31 & 47.40 & 47.95 & 47.23 & 46.90 & 47.52 & 41.10 & 40.75 & 40.37 & 50.24 & 52.36 & 48.59 & 45.83 & 43.20 & 39.35 & 47.57 & 40.93 & 42.04 \\
\hline $\mathrm{Al}_{2} \mathrm{C}$ & & 4.55 & 4.49 & 5.88 & 4.82 & 4.74 & 7.91 & & 8.03 & 1.96 & & & & 5.19 & 5. & 5.82 & & 17.72 \\
\hline $\mathrm{FeO}$, & 10.67 & 7.05 & 7.61 & 8.54 & 8.35 & 8.10 & 10.81 & 10.39 & 9.93 & 6.97 & 2.59 & 3.58 & 14.73 & 16.85 & 20.79 & 9.35 & 11.00 & 9.01 \\
\hline $\mathrm{MnO}$ & 0.00 & 0.00 & 0.08 & 0.05 & 0.18 & 0.06 & 0.37 & 0.00 & 0.00 & 0.00 & 0.00 & 0.03 & 0.25 & 0.02 & 0.00 & 0.00 & 0.00 & 0.26 \\
\hline $\mathrm{MgO}$ & 18.92 & 24.39 & 23.96 & 19.46 & 21.92 & 23.42 & 23.74 & 24.38 & 25.76 & 22.63 & & & & & 15.9 & 19.12 & 14.10 & 13.18 \\
\hline $\mathrm{CaC}$ & 23 & 88 & 84 & 1.47 & 1.02 & & 0.78 & & 1.94 & & & & & 1. & 1. & 1.4 & 2.67 & 3.06 \\
\hline $\mathrm{Na}_{2} \mathrm{O}$ & 87 & 94 & 85 & 0.83 & 0.90 & 0.79 & 0.23 & 0.19 & 0.29 & 0.2 & 0. & i. & 0. & 0.5 & 0.7 & 0.7 & 0.18 & 0.09 \\
\hline $\mathrm{K}, \mathrm{O}$ & 0.89 & 22 & 0.20 & 0.40 & 0.08 & 0.08 & 0.15 & 0.11 & 0.11 & 0.2 & & 0. & 2. & 2.5 & 1.4 & 0. & 0.30 & 0.26 \\
\hline $\mathrm{TiO}_{2}$ & 0.00 & 0.00 & 0.00 & 0.52 & 0.07 & 0.10 & 0.00 & 0.00 & 0.00 & 0.00 & 0.00 & 0.00 & 0.01 & 0.00 & 0.0 & 0.00 & 0.13 & 0.07 \\
\hline $\mathrm{Cr}_{2} \mathrm{O}_{3}$ & 0.00 & 0.00 & 0.00 & 0.01 & 0.00 & 0.00 & 0.00 & 0.00 & 0.00 & 0.00 & 0.00 & 0.00 & 0.00 & 0.00 & 0.00 & 0.00 & 0.00 & 0.49 \\
\hline Total & 85.16 & 85.42 & 86.04 & 84.37 & 84.24 & 85.77 & 85.10 & 84.37 & 86.42 & 82.78 & 85.39 & 85.14 & 86.71 & 86.16 & 85.52 & 84.62 & 85.47 & 86.16 \\
\hline $\mathrm{Si}$ & 3.58 & 3.55 & 3.57 & 3.60 & 3.58 & & & & & & & & & 3 & 3.2 & 3.63 & 3.13 & 3.15 \\
\hline $\mathrm{Al}^{\mathrm{IV}}$ & 56 & & & 0.53 & 0.43 & .42 & 0.72 & 0.72 & 0.72 & 0.18 & 0.31 & 0.48 & 0.56 & 0.49 & 0.52 & 0.5 & 1.45 & 1.56 \\
\hline $\mathrm{Al}^{\mathrm{vi}}$ & 00 & 00 & 00 & .00 & 0.00 & .00 & 0.00 & 0.00 & 0.00 & 0.0 & 0.00 & & & & & & 0.00 & 0.00 \\
\hline $\mathrm{Al}_{4}$ & 0.56 & 0.40 & 0.39 & 0.53 & 0.43 & 0.42 & 0.72 & 0.72 & 0.72 & 0.18 & 0.3 & 0.48 & 0.56 & 0.49 & 0.52 & 0.52 & 1.45 & 1.56 \\
\hline $\mathrm{Fe}_{1}$ & 0.67 & 0.44 & 0.47 & 0.54 & 0.53 & 0.51 & 0.70 & 0.68 & 0.63 & 0.44 & 0.16 & 0.22 & 0.96 & 1.13 & 1.44 & 0.60 & 0.70 & 0.56 \\
\hline $\mathrm{Mn}$ & 0.00 & & & 0.00 & 0.01 & 0.00 & 0.02 & 0.00 & 0.00 & 0.00 & 0.00 & 0.00 & 0.02 & 0.00 & 0.00 & 0.00 & 0.00 & 0.02 \\
\hline $\mathrm{Mg}$ & 2 & & & 1 & 2.49 & & & & 2.93 & & & & 1.79 & i. & is & & 1.61 & 1.47 \\
\hline $\mathrm{Ca}$ & 10 & 07 & 0.0 & 0.12 & 0.08 & & & & & & & & 0. & 0. & 0. & 0.11 & 0.22 & 0.25 \\
\hline $\mathrm{Na}$ & 0.13 & 14 & 0.12 & 0.12 & 0.13 & 0.11 & 0.04 & 0.0 & 0.04 & 0.0 & 0. & 0. & 0. & 0.0 & 0.1 & 0.11 & 0.03 & 0.01 \\
\hline K & 0.09 & 2 & 02 & 0.04 & 0.01 & 0.01 & 0.01 & 0.0 & 0.01 & 0.0 & 0.0 & 0. & 0. & 0.2 & 5 & 0.06 & 0.03 & 0.02 \\
\hline $\mathrm{Ti}$ & & & & & & & 0.00 & & 0.00 & & & & & & & & 0.01 & 0.00 \\
\hline $\mathrm{Cr}$ & 0.00 & 0.00 & 0.00 & 0.0 & 0.00 & & 0.00 & & 0.1 & & & & 0. & 0. & 0.00 & 0.00 & 0.00 & 0.03 \\
\hline Total & 7.25 & 7.33 & 7.31 & 7.19 & 7.27 & 7.29 & 7.48 & 7.49 & 7.58 & 7.11 & 7.09 & 7.27 & 7.32 & 7.48 & 7.62 & 7.20 & 7.17 & 7.07 \\
\hline
\end{tabular}

Notes: Formulas are calculated on the basis of 22 oxygens. $\mathrm{G}$ adj $=$ gray rock adjacent to alteration halo, $\mathrm{BH}=$ black halo, $\mathrm{BrH}=$ brown halo, $\mathrm{RH}=$ simple red halo, $\mathrm{CHRA}=\mathrm{Zone} \mathrm{A}$ of composite red halo, $\mathrm{CRHB}=\mathrm{Zone} \mathrm{B}$ of composite red halo, $\mathrm{CRHC}=\mathrm{Zone} \mathrm{C}$ of composite red halo, $\mathrm{CRHD}=\mathrm{Z}$ one $\mathrm{D}$ of composite red halo, Ves $\mathrm{c}=\mathrm{vesicle}$ core, Vesicle $=$ the whole vesicle, Oliv $\mathrm{c}=$ olivine core replacement, Oliv $\mathrm{t}=$ the whole olivine crystal, and Inter $=$ interstitial

vein (CRHA) to the gray inner rock $\left(\mathrm{G}\right.$ adj). The $\mathrm{H}_{2} \mathrm{O}^{+}$content generally follows this trend. The opposite trend which is sometimes observed may be ascribed to analytical reasons. The amount of rock powder used was sometimes too small to produce reliable $\mathrm{H}_{2} \mathrm{O}^{+}$content measurements.

The $\mathrm{Fe}_{2} \mathrm{O}_{31}$ contents of the three parts of these compound halos are higher than in the gray adjacent basalt, and fall in the range of composition of fresh glass. Three of the gray adjacent parts that we analyzed have less $\mathrm{Fe}_{2} \mathrm{O}_{3}$ than the fresh glass. $\mathrm{SiO}_{2}$ and $\mathrm{CaO}$ contents generally decrease regularly from the gray adjacent basalt to CRHA, whereas no systematic variations of the $\mathrm{MgO}$ and $\mathrm{Al}_{2} \mathrm{O}_{3}$ contents are observed.

The most spectacular effect of alteration is the $\mathrm{K}_{2} \mathrm{O}$ enrichment (up to $0.2 \mathrm{wt} \% \mathrm{~K}_{2} \mathrm{O}$ ) of Zone CRHA with respect to the other parts of the same samples: $0.04 \%$ to $0.10 \%$ in CRHB and CRHC, and $0.03 \%$ to $0.05 \%$ in the gray adjacent part (Fig. 12). Rb generally follows $\mathrm{K}_{2} \mathrm{O}$ variations. The high $\mathrm{K}_{2} \mathrm{O}$ content of CRHA is related to the occurrence of celadonitic minerals (Table 4 ). The gray adjacent basalt is only slightly $\mathrm{K}_{2} \mathrm{O}$-richer than fresh glass.

The simple halos (red, brown, black) are always more oxidized, more hydrated, and contain more $\mathrm{Fe}_{2} \mathrm{O}_{3}$ than the gray adjacent rock. The black halo is particularly rich in $\mathrm{K}_{2} \mathrm{O}$ and $\mathrm{Sr}(0.35 \mathrm{wt} \%$ and 11 ppm, respectively) and depleted in $\mathrm{Al}_{2} \mathrm{O}_{3}$ and $\mathrm{MgO}$. The brown halo is significantly enriched in $\mathrm{K}_{2} \mathrm{O}(0.19 \mathrm{wt} \%)$, and depleted in $\mathrm{CaO}$. Simple red halos show no significant $\mathrm{K}_{2} \mathrm{O}$ enrichment and are poorer in $\mathrm{SiO}_{2}$ than the adjacent gray basalt. The gray basalt adjacent to the brown halo is more altered $\left(\mathrm{H}_{2} \mathrm{O}^{+}, \mathrm{Fe}_{2} \mathrm{O}_{3 \mathrm{~L}}\right.$ and $\mathrm{K}_{2} \mathrm{O}$-enriched) than the gray basalt adjacent to other simple halos. This is probably because a small part of the brown halo was taken as gray adjacent basalt while sawing of sample. The other four gray adjacent basalts are slightly richer in $\mathrm{K}_{2} \mathrm{O}$ than the average of fresh glass, suggesting a slight $\mathrm{K}_{2} \mathrm{O}$ enrichment during the alteration of these parts of the samples.

\section{DISCUSSION}

\section{Alteration Conditions}

Oxygen isotope data suggest temperatures of up to $40^{\circ} \mathrm{C}$ for the formation of celadonite-nontronite in seafloor basalts (e.g., Seyfried et al., 1978; Böhlke et al., 1984). Such temperatures of alteration probably prevailed during the formation of black halos in Hole 896A basalts.

On the basis of studies of similar oceanic rocks (e.g., Andrews, 1977; Böhlke et al., 1980, 1981, 1984; Honnorez et al., 1983; Alt and Honnorez, 1984), the secondary mineralogy of Hole 896A basalts suggest alteration temperatures lower than $100^{\circ} \mathrm{C}$. Using the Cathelineau and Nieva's (1985) geothermometer, we calculated that the mixed-layer saponite-chlorite (type 6) from Hole 896A basalts crystallized at $50^{\circ}-80^{\circ} \mathrm{C}$. Saponite probably formed at still lower temperatures.

The major chemical and physical alterations clearly occurred in a seawater-dominated system. Secondary phases which precipitated from solutions are nearly stable in pristine seawater. Most of the latestage secondary minerals (zeolites and calcium carbonates) probably formed largely in response to an increase in $\mathrm{pH}$, caused by the consumption of $\mathrm{H}^{+}$related to the breakdown of plagioclase.

\section{Colored Alteration Halos in Hole 896A Basalts and Sequence of Alteration}

All types ( $\mathrm{CRH}, \mathrm{RH}, \mathrm{BrH}$, and $\mathrm{BH}$ ) of alteration halos which we describe above are clearly linked to the presence of clay minerals \pm $\mathrm{Fe}$-oxyhydroxide veins. On the contrary, no halos flank the later Cacarbonate bearing veins, and many carbonate veins cut across oxidation halos. Thus, oxidative alteration seems to have developed early, and generally before the main precipitation of $\mathrm{Ca}$-carbonates in veins.

The relative timing of development of the different oxidation styles is commonly ambiguous. Two possible general sequences of alteration can be proposed to explain the Hole 896A alteration features. One involves an early oxidative alteration during which iddingsite and celadonite-bearing minerals crystallized in the alteration halos adjacent to veins, followed by a widespread crystallization of saponite in and out of the halos. The alternate explanation involves early saponitic nonoxidative alteration, followed by oxidative alteration along a later generation of veins. A third vein generation, including $\mathrm{Ca}$-carbonate, is common to both the hypotheses. 
Table 4. Representative analyses of type 2 phyllosilicate (saponite), Hole 896A.

\begin{tabular}{|c|c|c|c|c|c|c|c|c|c|c|c|c|c|c|c|c|c|}
\hline Core, section: & $4 R-1$ & $4 \mathrm{R}-1$ & $4 \mathrm{R}-1$ & $4 \mathrm{R}-1$ & $4 \mathrm{R}-1$ & $9 \mathrm{R}-2$ & $9 \mathrm{R}-2$ & $9 \mathrm{R}-2$ & 10R-1 & 23R-2 & 10R-1 & $17 R-3$ & $17 R-3$ & $17 R-3$ & $17 R-3$ & $17 R-4$ & $17 R-4$ \\
\hline Interval $(\mathrm{cm})$ : & $37-44$ & $37-44$ & $37-44$ & $37-44$ & $37-44$ & $14-17$ & $14-17$ & $14-17$ & $57-60$ & $0-6$ & $57-60$ & $43-45$ & $43-45$ & $43-45$ & $43-45$ & $15-20$ & $15-20$ \\
\hline Piece no.: & 8 & 8 & 8 & 8 & 8 & 2 & 2 & 2 & $8 \mathrm{~A}$ & IA & $8 \mathrm{~A}$ & 4 & 4 & 4 & 4 & $2 \mathrm{C}$ & $2 \mathrm{C}$ \\
\hline Depth (mbsf): & 219.3 & 219.3 & 219.3 & 219.3 & 219.3 & 268.2 & 268.2 & 268.2 & 276.9 & 393.6 & 276.9 & 347 & 346.8 & 346.8 & 346.8 & 348.1 & 348.1 \\
\hline Rock type: & G adj & $\mathrm{G}$ adj & $\mathrm{G}$ adj & $\mathrm{BrH}$ & $\mathrm{BrH}$ & Pillow r & Pillow $\mathrm{r}$ & Pillow $\mathrm{r}$ & $\mathrm{BrH}$ & G adj & $\mathrm{BrH}$ & $\mathrm{BH}$ & $\mathrm{BH}$ & BH & $\mathrm{BH}$ & CRHD & CRHA \\
\hline Occurrence: & Oliv $\mathrm{t}$ & Oliv $t$ & Oliv $\mathrm{t}$ & Plag & Vein & Vein & Vein & Plag & Vein & Oliv $t$ & Vein & Oliv c & Oliv c & Oliv c & Oliv c & Oliv c & Vein \\
\hline Analysis no.: & M98 & M99 & M102 & Mili & $\mathrm{M} 124$ & $\mathrm{M} 117$ & M118 & M135 & MI80 & M44 & M181 & M6 & M89 & M91 & M93 & M155 & M156 \\
\hline $\mathrm{SiO}_{2}$ & 48.92 & 46.52 & 47.22 & 40.20 & 45.21 & 47.20 & 45.17 & 49.67 & 48.88 & 50.05 & 48.11 & 48.38 & 47.97 & 46.99 & 46.05 & 36.68 & 37.03 \\
\hline $\mathrm{Al}_{3} \mathrm{O}_{3}$ & 4.99 & 5.42 & 5.28 & 12.65 & 7.22 & 5.10 & 5.78 & 5.23 & 3.58 & 2.41 & 3.48 & 3.96 & 3.82 & 4.04 & 4.07 & 9.92 & 10.36 \\
\hline $\mathrm{FeO}$ & 9.70 & 10.51 & 10.67 & 11.57 & 9.04 & 10.84 & 11.64 & 10.50 & 9.10 & 7.58 & 9.08 & 6.82 & 12.21 & 7.17 & 7.84 & 15.24 & 15.43 \\
\hline $\mathrm{MnO}$ & 0.00 & 0.00 & 0.00 & 0.00 & 0.00 & 0.00 & 0.00 & 0.00 & 0.00 & 0.00 & 0.00 & 0.00 & 0.00 & 0.03 & 0.04 & 0.00 & 0.00 \\
\hline $\mathrm{MgO}$ & 18.94 & 19.68 & 19.76 & 20.30 & 19.35 & 19.73 & 20.07 & 19.08 & 20.40 & 21.65 & 20.26 & 23.33 & 21.78 & 23.99 & 24.70 & 18.41 & 19.33 \\
\hline $\mathrm{CaO}$ & 0.30 & 0.32 & 0.44 & 0.85 & 1.03 & 1.58 & 1.61 & 1.83 & 0.80 & 0.68 & 0.89 & 0.66 & 0.70 & 0.85 & 0.75 & 0.55 & 1.01 \\
\hline $\mathrm{Na}_{2} \mathrm{O}$ & 0.71 & 1.25 & 1.19 & 0.35 & 0.84 & 0.41 & 0.35 & 0.60 & 0.73 & 0.37 & 0.56 & 0.31 & 0.43 & 0.58 & 0.66 & 0.15 & 0.10 \\
\hline $\mathrm{K}_{2} \mathrm{O}$ & 0.19 & 0.23 & 0.35 & 0.15 & 0.09 & 0.13 & 0.23 & 0.21 & 0.18 & 0.15 & 0.18 & 0.16 & 0.53 & 0.26 & 0.28 & 0.07 & 0.08 \\
\hline $\mathrm{TiO}_{2}$ & 0.00 & 0.00 & 0.00 & 0.00 & 0.00 & 0.00 & 0.00 & 0.00 & 0.00 & 0.00 & 0.00 & 0.00 & 0.00 & 0.00 & 0.00 & 0.00 & 0.00 \\
\hline $\mathrm{Cr}_{2} \mathrm{O}_{3}$ & 0.00 & 0.00 & 0.00 & 0.00 & 0.00 & 0.00 & 0.00 & 0.00 & 0.00 & 0.00 & 0.00 & 0.00 & 0.58 & 0.03 & 0.13 & 0.00 & 0.00 \\
\hline Total & 83.74 & 83.93 & 84.90 & 86.07 & 82.78 & 84.99 & 84.84 & 87.11 & 83.66 & 82.88 & 82.55 & 83.62 & 88.02 & 83.93 & 84.51 & 81.02 & 83.33 \\
\hline $\mathrm{Si}$ & 3.73 & 3.59 & 3.61 & 3.07 & 3.51 & 3.60 & 3.49 & 3.68 & 3.74 & 3.82 & 3.73 & 3.66 & 3.58 & 3.58 & 3.51 & 3.06 & 3.01 \\
\hline $\mathrm{Al}^{\mathrm{IV}}$ & 0.45 & 0.49 & 0.48 & 1.14 & 0.66 & 0.46 & 0.53 & 0.46 & 0.32 & 0.22 & 0.32 & 0.35 & 0.34 & 0.36 & 0.37 & 0.98 & 0.99 \\
\hline $\mathrm{Al}^{\mathrm{VI}}$ & 0.00 & 0.00 & 0.00 & 0.00 & 0.00 & 0.00 & 0.00 & 0.00 & 0.00 & 0.00 & 0.00 & 0.00 & 0.00 & 0.00 & 0.00 & 0.00 & 0.00 \\
\hline $\mathrm{Al}_{i}$ & 0.45 & 0.49 & 0.48 & 1.14 & 0.66 & 0.46 & 0.53 & 0.46 & 0.32 & 0.22 & 0.32 & 0.35 & 0.34 & 0.36 & 0.37 & 0.98 & 0.99 \\
\hline $\mathrm{Fe}_{1}$ & 0.62 & 0.68 & 0.68 & 0.74 & 0.59 & 0.69 & 0.75 & 0.65 & 0.58 & 0.48 & 0.59 & 0.43 & 0.76 & 0.46 & 0.50 & 1.06 & 1.05 \\
\hline $\mathrm{Mn}$ & 0.00 & 0.00 & 0.00 & 0.00 & 0.00 & 0.00 & 0.00 & 0.00 & 0.00 & 0.00 & 0.00 & 0.00 & 0.00 & 0.00 & 0.00 & 0.00 & 0.00 \\
\hline $\mathrm{Mg}$ & 2.15 & 2.27 & 2.25 & 2.31 & 2.24 & 2.25 & 2.31 & 2.11 & 2.33 & 2.46 & 2.34 & 2.63 & 2.42 & 2.72 & 2.80 & 2.29 & 2.34 \\
\hline $\mathrm{Ca}$ & 0.02 & 0.03 & 0.04 & 0.07 & 0.09 & 0.13 & 0.13 & 0.15 & 0.07 & 0.06 & 0.07 & 0.05 & 0.06 & 0.07 & 0.06 & 0.05 & 0.09 \\
\hline $\mathrm{Na}$ & 0.10 & 0.19 & 0.18 & 0.05 & 0.13 & 0.06 & 0.05 & 0.09 & 0.11 & 0.05 & 0.08 & 0.05 & 0.06 & 0.09 & 0.10 & 0.02 & 0.02 \\
\hline K & 0.02 & 0.02 & 0.03 & 0.01 & 0.01 & 0.01 & 0.02 & 0.02 & 0.02 & 0.01 & 0.02 & 0.02 & 0.05 & 0.03 & 0.03 & 0.01 & 0.01 \\
\hline $\mathrm{Ti}$ & 0.00 & 0.00 & 0.00 & 0.00 & 0.00 & 0.00 & 0.00 & 0.00 & 0.00 & 0.00 & 0.00 & 0.00 & 0.00 & 0.00 & 0.00 & 0.00 & 0.00 \\
\hline $\mathrm{Cr}$ & 0.00 & 0.00 & 0.00 & 0.00 & 0.00 & 0.00 & 0.00 & 0.00 & 0.00 & 0.00 & 0.00 & 0.00 & 0.03 & 0.00 & 0.01 & 0.00 & 0.00 \\
\hline Total & 7.10 & 7.27 & 7.26 & 7.39 & 7.22 & 7.20 & 7.29 & 7.14 & 7.16 & 7.11 & 7.16 & 7.19 & 7.30 & 7.30 & 7.37 & 7.47 & 7.51 \\
\hline
\end{tabular}

The most common configuration of Hole $896 \mathrm{~A}$ alteration halos (i.e., inner gray part, and outer oxidized halos adjacent to exposed surfaces and fractures) suggests that alteration started with an oxidative stage. As the fluid penetrated into the rock perpendicular to the vein, it reacted with the rock, and its chemical composition and the chemical conditions evolved. A reducing alteration then took place. Such a sequence was also proposed for Hole 504B (Alt et al., 1986; Laverne et al., 1989) and at Site 417 (Alt and Honnorez, 1984).

\section{Nature of Altering Fluids}

It is commonly admitted that the fluid involved in the formation of red halos is unevolved seawater (Honnorez, 1981). However, the $\mathrm{Fe}$-enrichment of celadonite-nontronite-bearing black halos cannot be caused by a reaction with unevolved seawater. Fe must come from an external source. In the young $(0.54-2.73 \mathrm{~m}$.y. old $)$ basalts from the Galapagos Spreading Center, it is shown that the iron necessary to form celadonite and nontronite occurring in black halos cannot be provided by the alteration of primary minerals such as clinopyroxene, which is fresh, and olivine, which, when present, is generally fresh (Laverne and Vivier, 1983; Laverne, 1987). Fe may come from the conversion of titanomagnetite to titanomaghemite (Petersen, 1979), from local breakdown of glass, or from reactions occurring at greater depths (Alt, in press). On the other hand, celadonite and nontronite typically form in some low-temperature $\left(30^{\circ}-60^{\circ} \mathrm{C}\right)$ seafloor hydrothermal deposits (Hoffert et al., 1978; Alt, 1988). It is then proposed that black halos form earlier than red and brown oxidized alteration halos from low-temperature $\left(30^{\circ}-60^{\circ} \mathrm{C}\right) \mathrm{Fe}$-rich upwelling hydrothermal fluids close to the spreading axis (Alt and Honnorez, 1984; Böhlke et al., 1984; Laverne, 1987, 1993; Buatier, 1989; Buatier et al., 1989).

Among the three samples of black halos recovered from Hole $896 \mathrm{~A}$, only one could be sampled and studied. By analogy with the mineralogical features of black halos from other oceanic basalts, we propose that the fluids involved in the formation of Hole 896A black halos are mixed fluids.

In Hole 896A, the brown halos and the zones of composite red halos (CRHA) which are in contact with the vein show the same mineralogical composition as black halos, and also show a clear $\mathrm{K}_{2} \mathrm{O}$ enrichment, although less significant in CRHA than in black halos. We thus propose that CRHA and brown halos represent early black halos which would have been oxidized later by unevolved seawater.

\section{Lithological Control on Alteration Style}

A strong lithological control on alteration style (i.e., on the access of oxygenated fluids to the primary igneous rocks) is readily apparent: many massive units contain several highly oxidized zones, whereas pillow basalt units have only sporadic oxidative alteration. One commonly observes in the oceanic crust that the glassy rim of a given pillow remains unaltered whereas the finely crystallized core of the pillow is altered. This is explained by the fact that fresh basaltic glass is less porous, because it contains no grain boundaries. The diffusion of the fluids from the open cracks to the interior of the basaltic pieces mainly occurs along grain boundaries. Similarly, the primary porosity of the fine pillow basalts is probably lower than that of coarser grained basalts composing the massive units.

\section{Comparison with Upper Volcanics from Hole 504B}

As from Hole 504B, no sample from Hole 896A is completely fresh. The major mineralogical and chemical features of alteration evidenced in the $310 \mathrm{~m}$ of basalts forming the upper pillow alteration zone (UPAZ) of Hole 504B are similar to those observed in Hole $896 \mathrm{~A}$. The main differences in the alteration features between Hole 896 A and the UPAZ of Hole 504B are (1) the larger amount of secondary minerals in Hole 896A, which is clearly seen in the thickness and particularly the abundance of saponite and Ca-carbonate veins; (2) the presence of compound oxidative alteration halos in Hole $896 \mathrm{~A}$; (3) the fact that black halos in Hole 896 A are scarce, relatively thick, and never adjacent to red halos. However, probable black halos and red halos coexisting in a given sample are observed in Hole $896 \mathrm{~A}$. In such a case, red halos or brown halos are totally superimposed to black halos. This suggests that the oxidative stage of alteration (responsible for the formation of red halos) was more pronounced in Hole 896A than in Hole 504B. This can be explained by a higher water/rock ratio, related to a higher permeability of basalts from Hole $896 \mathrm{~A}$ before alteration. 
Table 4 (continued)

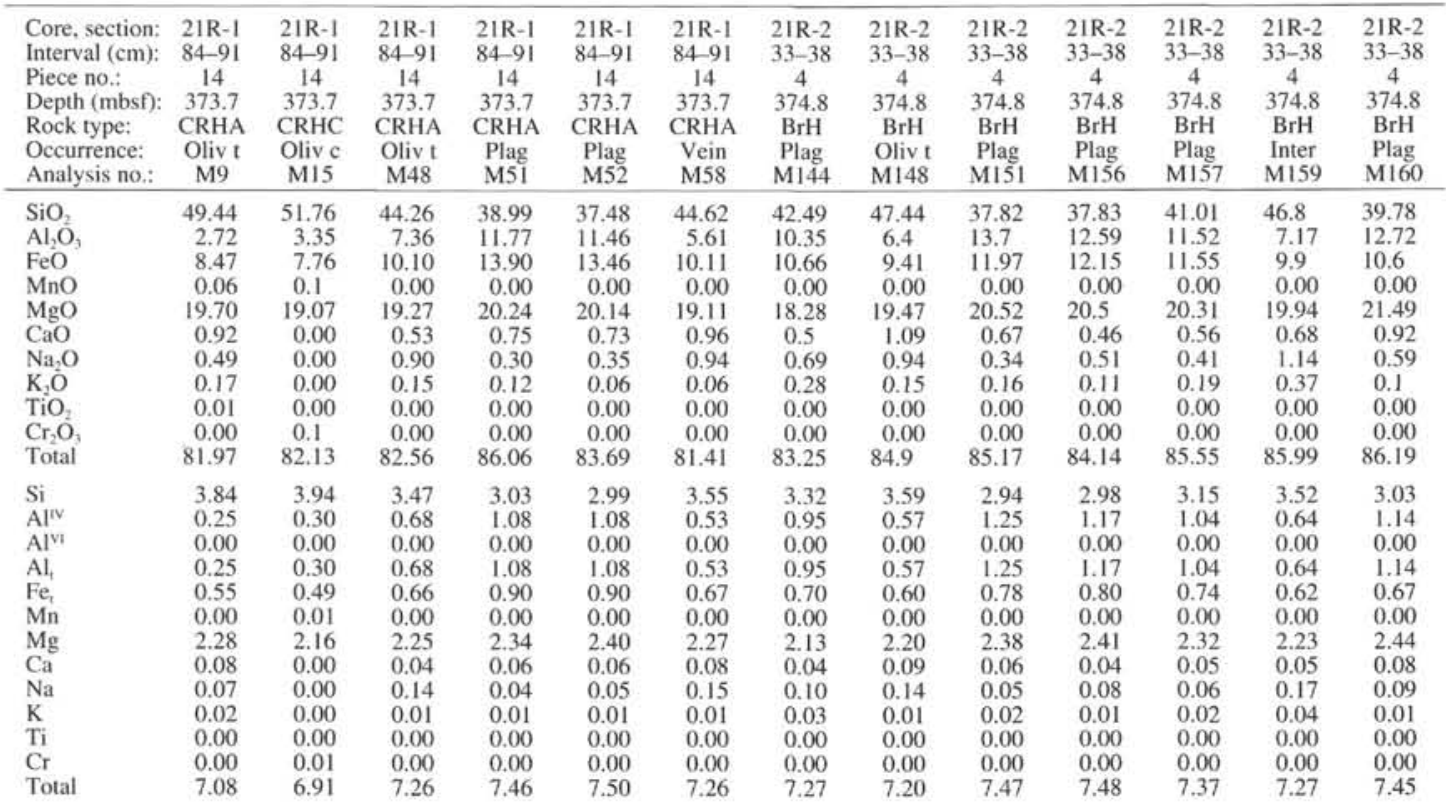

Notes: Formulas calculated on the basis of 22 oxygens. Abbreviations as in Table 3 , with the addition of Pillow $\mathrm{r}=$ pillow rim, Plag $=$ plagioclase, and Ves $\mathrm{r}=$ vesicle rim.

\section{CONCLUSIONS}

Alteration effects in Hole $896 \mathrm{~A}$ basalts are chiefly visible as veins, as breccia cements, and as variously colored halos which are 3 $\mathrm{mm}$ to $50 \mathrm{~mm}$ in thickness. Alteration of the basalt pile of Hole 896A was dominated by low temperature $\left(<100^{\circ} \mathrm{C}\right)$ oxidative reactions. There is no apparent trend with downhole depth in either the alteration mineralogy and chemistry or the overall extent to which alteration proceeded.

A strong lithological control on alteration style is readily apparent. The large number of highly oxidized basalts contained in the massive units compared to the discrete oxidative alteration of the pillow basalts units is explained by the fact that the diffusion of the fluids along grain boundaries is easier in the coarse-grained basalts composing the massive units.

Clay minerals are the most common and abundant secondary minerals in Hole 896A basalts. Most of them are saponites. Common celadonite, celadonite-nontronite mixtures, celadonite-nontronite-saponite mixtures, and saponite-celadonite-iron oxide mixtures also occur. Calcite and aragonite are abundant in veins. Phillipsite, chabazite and pyrite are the least abundant secondary minerals.

All four types of alteration halos are more oxidized, more hydrated, and richer in Fe than the adjacent gray rock. The black halo and the part of the compound red halos that is in contact with the vein are clearly enriched in $\mathrm{K}_{2} \mathrm{O}$ (and $\mathrm{Rb}$ in the case of black halos) compared to the gray adjacent basalt. This is related to the presence of celadonite-bearing minerals. Alteration halos are generally richer in $\mathrm{Si}$ and $\mathrm{Ca}$ than the adjacent gray rocks. Other elements (e.g., $\mathrm{Mg}, \mathrm{Al}, \mathrm{Sr}$ ), do not show any systematic variation.

Although several exceptions exist, the most common configuration of oxidized halos suggests that alteration started with an oxidative stage. The chemical composition of the fluid evolved while moving into the basalt, leading to a reducing alteration stage with saponite precipitation in the adjacent gray basalt. Most of the late-stage secondary minerals (zeolites and Ca-carbonates) probably formed largely in response to an increase in $\mathrm{pH}$, because of the consumption of $\mathrm{H}^{+}$related to the breakdown of plagioclase. The main fluid involved in this alteration is probably seawater.

In three samples from Hole $896 \mathrm{~A}$ basalts, the alteration only appears by the occurrence of black halos. The secondary mineralogy (celadonite-nontronite) and the chemical features (enrichment in $\mathrm{K}$ and $\mathrm{Fe}_{t}$ ) of black halos imply the contribution of Fe-rich, diluted hydrothermal fluids during their formation. In this case, hydrothermal fluids percolated the seawater-impregnated basalt.

The brown halos and the zones of composite red halos (CRHA) which are in contact with the vein show the same mineralogical composition as black halos and also show a clear $\mathrm{K}_{2} \mathrm{O}$ enrichment. The CRHA zones and the brown halos probably are red halos superimposed to black halos in a two-stage alteration process: (1) alteration with hydrothermal fluids mixed with seawater, which produces black halos; (2) oxidizing alteration by seawater, which oxidizes black halos.

The alteration features observed in Hole 896A basalts are generally similar to that of the upper volcanics of Hole 504B. However, in contrast to Hole 504B, black halos adjacent to red halos were not observed in Hole 896A. It means that, in most of Hole 896A basalts, the oxidizing, seawater dominated, stage of alteration was more pronounced than in Hole 504B basalts. The effects of the oxidizing alteration are completely superimposed to that of earlier low-temperature hydrothermal alteration. This suggests that, before its alteration, the crust was more permeable at Site 896 than at Site 504.

\section{ACKNOWLEDGMENTS}

This research was supported by CNRS-INSU to J.H. and C.L. We thank J.-C. Girard for making thin sections from a difficult expanding material, M.-O. Trenz for making chemical analyses of small quantities of rocks, and J.C. Alt and L. Bettison-Varga for reviewing the manuscript.

\section{REFERENCES}

Alt, J.C., 1988. Hydrothermal oxide and nontronite deposits on seamounts in the eastern Pacific. Mar. Geol., 81:227-239.

1984. The structure, chemistry, and evolution of a submarine hydrothermal system, DSDP Site 504 [Ph.D. dissert.]. Univ. of Miami, Miami, FL.

, in press. Subseafloor processes in mid-ocean ridge hydrothermal systems. In Lupton, J., Mullineaux, L., and Zierenberg, R. (Eds.), RIDGE Theoretical Institute: Physical Chemical and Biological Interactions 
Table 5. Representative analyses of type 3 phyllosilicate (mixture of celadonite and nontronite), Hole 896A.

\begin{tabular}{|c|c|c|c|c|c|c|c|c|c|c|c|c|c|c|}
\hline $\begin{array}{l}\text { Core, section: } \\
\text { Interval }(\mathrm{cm}): \\
\text { Piece no.: } \\
\text { Depth (mbsf): } \\
\text { Rock type: } \\
\text { Occurrence: } \\
\text { Analysis no.: }\end{array}$ & $\begin{array}{c}17 \mathrm{R}-3 \\
43-45 \\
4 \\
346.8 \\
\text { BH } \\
\text { Oliv r } \\
\text { M16 } \\
\end{array}$ & $\begin{array}{c}17 \mathrm{R}-3 \\
43-45 \\
4 \\
346.8 \\
\text { BH } \\
\text { Oliv r } \\
\text { M19 } \\
\end{array}$ & $\begin{array}{c}17 \mathrm{R}-3 \\
43-45 \\
4 \\
346.8 \\
\text { BH } \\
\text { Oliv r } \\
\text { M20 } \\
\end{array}$ & $\begin{array}{c}17 \mathrm{R}-3 \\
43-45 \\
4 \\
346.8 \\
\text { BH } \\
\text { Oliv r } \\
\text { M21 }\end{array}$ & $\begin{array}{c}\text { I7R-3 } \\
43-45 \\
4 \\
346.8 \\
\text { BH } \\
\text { Oliv r } \\
\text { M22 }\end{array}$ & $\begin{array}{c}17 \mathrm{R}-3 \\
43-45 \\
4 \\
346.8 \\
\text { BH } \\
\text { Oliv r } \\
\text { M23 }\end{array}$ & $\begin{array}{c}17 \mathrm{R}-3 \\
43-45 \\
4 \\
346.8 \\
\text { BH } \\
\text { Oliv r } \\
\text { M25 }\end{array}$ & $\begin{array}{c}17 \mathrm{R}-3 \\
43-45 \\
4 \\
346.8 \\
\text { BH } \\
\text { Oliv r } \\
\text { M27 }\end{array}$ & $\begin{array}{c}17 \mathrm{R}-3 \\
43-45 \\
4 \\
346.8 \\
\text { BH } \\
\text { Oliv r } \\
\text { M28 } \\
\end{array}$ & $\begin{array}{c}17 \mathrm{R}-3 \\
43-45 \\
4 \\
346.8 \\
\text { BH } \\
\text { Oliv r } \\
\text { M30 }\end{array}$ & $\begin{array}{c}17 \mathrm{R}-3 \\
43-45 \\
4 \\
346.8 \\
\text { BH } \\
\text { Oliv r } \\
\text { M31 }\end{array}$ & $\begin{array}{c}2 \text { IR-1 } \\
84-91 \\
14 \\
373.7 \\
\text { CRHA } \\
\text { Ves r } \\
\text { M40 }\end{array}$ & $\begin{array}{c}23 \mathrm{R}-2 \\
0-6 \\
1 \mathrm{~A} \\
393.6 \\
\text { CRHA } \\
\text { Ves r } \\
\text { M81 }\end{array}$ & $\begin{array}{c}\text { I7R-3 } \\
43-45 \\
4 \\
346.8 \\
\text { BH } \\
\text { Oliv r } \\
\text { M32 }\end{array}$ \\
\hline $\begin{array}{l}\mathrm{SiO}_{2} \\
\mathrm{Al}_{2} \mathrm{O}_{3} \\
\mathrm{FeO}_{4} \\
\mathrm{MnO} \\
\mathrm{MgO} \\
\mathrm{CaO} \\
\mathrm{Na}_{2} \mathrm{O} \\
\mathrm{K}_{2} \mathrm{O} \\
\mathrm{TiO}_{2} \\
\mathrm{Cr}_{2} \mathrm{O}_{3} \\
\text { Total }\end{array}$ & $\begin{array}{r}50.40 \\
3.76 \\
25.15 \\
0.00 \\
5.50 \\
0.73 \\
0.46 \\
6.97 \\
0.04 \\
0.42 \\
93.44\end{array}$ & $\begin{array}{r}53.17 \\
1.83 \\
24.39 \\
0.29 \\
5.17 \\
0.56 \\
0.35 \\
7.96 \\
0.03 \\
0.00 \\
93.73\end{array}$ & $\begin{array}{r}49.93 \\
2.13 \\
24.25 \\
0.00 \\
6.53 \\
0.84 \\
0.28 \\
8.02 \\
0.11 \\
0.62 \\
92.71\end{array}$ & $\begin{array}{r}51.73 \\
1.88 \\
24.21 \\
0.53 \\
6.02 \\
0.54 \\
0.17 \\
7.96 \\
0.03 \\
0.14 \\
93.20\end{array}$ & $\begin{array}{r}52.12 \\
1.76 \\
24.23 \\
0.00 \\
6.05 \\
0.45 \\
0.32 \\
8.06 \\
0.02 \\
0.00 \\
93.00\end{array}$ & $\begin{array}{r}52.47 \\
1.76 \\
24.25 \\
0.00 \\
5.72 \\
0.45 \\
0.33 \\
8.06 \\
0.03 \\
0.00 \\
93.06\end{array}$ & $\begin{array}{r}52.86 \\
1.86 \\
25.09 \\
0.00 \\
5.75 \\
0.43 \\
0.34 \\
7.84 \\
0.06 \\
0.03 \\
94.25\end{array}$ & $\begin{array}{r}51.90 \\
2.04 \\
25.48 \\
0.00 \\
5.73 \\
0.59 \\
0.34 \\
7.61 \\
0.13 \\
1.81 \\
95.62\end{array}$ & $\begin{array}{r}50.58 \\
1.70 \\
25.41 \\
0.00 \\
5.47 \\
0.45 \\
0.33 \\
8.05 \\
0.03 \\
0.00 \\
92.00\end{array}$ & $\begin{array}{r}53.37 \\
2.13 \\
24.06 \\
0.00 \\
7.46 \\
0.38 \\
0.28 \\
8.02 \\
0.05 \\
0.00 \\
95.76\end{array}$ & $\begin{array}{r}51.97 \\
1.89 \\
24.66 \\
0.00 \\
6.08 \\
0.50 \\
0.32 \\
7.84 \\
0.07 \\
0.02 \\
93.34\end{array}$ & $\begin{array}{r}43.67 \\
3.46 \\
32.40 \\
0.19 \\
3.90 \\
1.04 \\
0.28 \\
6.11 \\
0.04 \\
0.00 \\
91.09\end{array}$ & $\begin{array}{r}45.91 \\
2.06 \\
28.61 \\
0.00 \\
4.17 \\
0.51 \\
0.40 \\
7.44 \\
0.00 \\
0.00 \\
89.10\end{array}$ & $\begin{array}{r}49.41 \\
1.61 \\
25.29 \\
0.00 \\
5.84 \\
0.37 \\
0.14 \\
8.57 \\
0.04 \\
0.95 \\
92.22\end{array}$ \\
\hline $\begin{array}{l}\mathrm{Si} \\
\mathrm{Al}^{\mathrm{Iv}} \\
\mathrm{Al}^{\mathrm{vi}} \\
\mathrm{Al} \\
\mathrm{Fe}_{1} \\
\mathrm{Mn} \\
\mathrm{Mg} \\
\mathrm{Ca} \\
\mathrm{Na} \\
\mathrm{K} \\
\mathrm{Ti} \\
\mathrm{Cr} \\
\mathrm{Total}\end{array}$ & $\begin{array}{l}3.88 \\
0.34 \\
0.00 \\
0.34 \\
1.62 \\
0.00 \\
0.63 \\
0.06 \\
0.07 \\
0.68 \\
0.00 \\
0.03 \\
7.31\end{array}$ & $\begin{array}{l}4.06 \\
0.16 \\
0.00 \\
0.16 \\
1.56 \\
0.02 \\
0.59 \\
0.05 \\
0.05 \\
0.78 \\
0.00 \\
0.00 \\
7.27\end{array}$ & $\begin{array}{l}3.90 \\
0.20 \\
0.00 \\
0.20 \\
1.58 \\
0.00 \\
0.76 \\
0.07 \\
0.04 \\
0.80 \\
0.01 \\
0.04 \\
7.40\end{array}$ & $\begin{array}{l}3.99 \\
0.17 \\
0.00 \\
0.17 \\
1.56 \\
0.03 \\
0.69 \\
0.04 \\
0.03 \\
0.78 \\
0.00 \\
0.01 \\
7.32\end{array}$ & $\begin{array}{l}4.02 \\
0.16 \\
0.00 \\
0.16 \\
1.56 \\
0.00 \\
0.70 \\
0.04 \\
0.05 \\
0.79 \\
0.00 \\
0.00 \\
7.32\end{array}$ & $\begin{array}{l}4.04 \\
0.16 \\
0.00 \\
0.16 \\
1.56 \\
0.00 \\
0.66 \\
0.04 \\
0.05 \\
0.79 \\
0.00 \\
0.00 \\
7.30\end{array}$ & $\begin{array}{l}4.02 \\
0.17 \\
0.00 \\
0.17 \\
1.60 \\
0.00 \\
0.65 \\
0.04 \\
0.05 \\
0.76 \\
0.00 \\
0.00 \\
7.29\end{array}$ & $\begin{array}{l}3.93 \\
0.18 \\
0.00 \\
0.18 \\
1.61 \\
0.00 \\
0.65 \\
0.05 \\
0.05 \\
0.73 \\
0.01 \\
0.11 \\
7.31\end{array}$ & $\begin{array}{l}3.99 \\
0.16 \\
0.00 \\
0.16 \\
1.68 \\
0.00 \\
0.64 \\
0.04 \\
0.05 \\
0.81 \\
0.00 \\
0.00 \\
7.36\end{array}$ & $\begin{array}{l}3.98 \\
0.19 \\
0.00 \\
0.19 \\
1.50 \\
0.00 \\
0.83 \\
0.03 \\
0.04 \\
0.76 \\
0.00 \\
0.00 \\
7.33\end{array}$ & $\begin{array}{l}4.00 \\
0.17 \\
0.00 \\
0.17 \\
1.59 \\
0.00 \\
0.70 \\
0.04 \\
0.05 \\
0.77 \\
0.00 \\
0.00 \\
7.32\end{array}$ & $\begin{array}{l}3.64 \\
0.34 \\
0.00 \\
0.34 \\
2.26 \\
0.01 \\
0.49 \\
0.09 \\
0.05 \\
0.65 \\
0.00 \\
0.00 \\
7.53\end{array}$ & $\begin{array}{l}3.85 \\
0.20 \\
0.00 \\
0.20 \\
2.00 \\
0.00 \\
0.52 \\
0.05 \\
0.07 \\
0.79 \\
0.00 \\
0.00 \\
7.48\end{array}$ & $\begin{array}{l}3.92 \\
0.15 \\
0.00 \\
0.15 \\
1.68 \\
0.00 \\
0.69 \\
0.03 \\
0.02 \\
0.87 \\
0.00 \\
0.06 \\
7.42\end{array}$ \\
\hline
\end{tabular}

Within Submarine Hydrothermal Systems. Geophys. Monogr., Am. Geophys. Union.

Alt, J.C., and Honnorez, J., 1984. Alteration of the upper oceanic crust, DSDP Site 417: mineralogy and chemistry. Contrib. Mineral. Petrol., 87:149-169.

Alt, J.C., Honnorez, J., Laverne, C., and Emmermann, R., 1986. Hydrothermal alteration of a $1 \mathrm{~km}$ section through the upper oceanic crust, Deep Sea Drilling Project Hole 504B: mineralogy, chemistry, and evolution of seawater-basalt interactions. J. Geophys. Res., 91:10309-10335.

Andrews, A.J., 1977. Low-temperature fluid alteration of oceanic layer 2 basalts, DSDP Leg 37. Can. J. Earth Sci., 14:911-926.

Bettison, L.A., and Schiffman, P., 1988. Compositional and structural variations of phyllosilicates from the Point Sal ophiolite, California. Am. Mineral., 73:62-76.

Bevins, R.E., Robinson, D., and Rowbotham, G., 1991. Compositional variations in mafic phyllosilicates from regional low-grade metabasites and application of the chlorite geothermometer. J. Metamorph. Geol., 9:711721 .

Böhlke, J.K., Alt, J.C., and Muehlenbachs, K., 1984. Oxygen isotope-water relations in altered deep-sea basalts: low temperature mineralogical controls. Can. J. Earth Sci., 21:67-77.

Böhlke, J.K., Honnorez, J., and Honnorez-Guerstein, B.M., 1980. Alteration of basalts from site 396B, DSDP: petrographic and mineralogical studies. Contrib. Mineral. Petrol., 73:341-364.

Böhlke, J.K., Honnorez, J., Honnorez-Guerstein, B.M., Muehlenbachs, K., and Petersen, N., 1981. Heterogeneous alteration of the upper oceanic crust: correlation of rock chemistry, magnetic properties, and O-isotope ratios with alteration patterns in basalts from DSDP Site 396B. J. Geophys. Res., 86:7935-7950.

Buatier, M., 1989. Genèse et évolution des argiles vertes hydrothermales océaniques: les "monts" du rift des Galapagos (Pacifique équatorial) [Thèse Doc. Sc.]. Univ. Strasbourg.

Buatier, M., Honnorez, J., and Ehret, G., 1989. Fe-smectite-glauconite transition in hydrothermal clays from Galapagos Spreading Center. Clays Clay Miner., 37:532-541.

Cathelineau, M., and Nieva, D., 1985. A chlorite solid solution geothermometer: the Loz Azufres (Mexico) geothermal system. Contrib. Mineral. Petrol., 91:235-244.

Donnelly, T., Francheteau, J., Bryan, W., Robinson, P., Flower, M., Salisbury, M., et al., 1979. Init. Repts. DSDP, 51, 52, 53: Washington (U.S. Govt. Printing Office).
Fisher, A., Becker, K., Narasimhan, T.N., Langseth, M., and Mottl, M., 1990. Passive, off-axis convection on the southern flank of the Costa Rica Rift. J. Geophys. Res., 95:9343-9370.

Germanique, J.C., 1994. Major, trace and rare-earth elements in fourteen GSJ reference samples. Determination by X-ray fluorescence spectrometry and inductively coupled plasma optical emission spectrometry. Geostand. Newsl., 18:1:91-100.

Hoffert, M., Perseil, A., Hekinian, R., Choukroune, P., Needham, J., Francheteau, J., and Lepichon, X., 1978. Hydrothermal deposits sampled by diving saucer in Transform fault near $37^{\circ} \mathrm{N}$ on the Mid-Atlantic Ridge FAMOUS area. Oceanol. Acta, 1:73-86.

Honnorez, J., 1981. The aging of the oceanic crust at low temperature. In Emiliani, C. (Ed.), The Sea (Vol. 7): The Oceanic Lithosphere: New York (Wiley), 525-587.

Honnorez, J., Laverne, C., Hubberten, H.-W., Emmermann, R., and Muehlenbachs, K., 1983. Alteration processes in Layer 2 basalts from Deep Sea Drilling Project Hole 504B, Costa Rica Rift. In Cann, J.R., Langseth, M.G., Honnorez, J., Von Herzen, R.P., White, S.M., et al., Init. Repts. DSDP, 69: Washington (U.S. Govt. Printing Office), 509-546.

Laverne, C., 1987. Les altérations des basaltes en domaine océanique: minéralogie, pétrologie et géochimie d'un système hydrothermal: le puits 504B, Pacifique oriental [Thèse de Doctorat d'Etat]. Univ. Aix-Marseille III.

, 1993. Occurrence of siderite and ankerite in young basalts from the Galapagos Spreading Center (DSDP Holes 506G and 507B). Chem. Geol., 106:27-46.

Laverne, C., Honnorez, J., and Alt, J.C., 1989. Transition entre l'altération à basse température et le métamorphisme hydrothermal de la croûte océanique: étude pétrographique et géochimique du puits 504B, Est-Pacifique. Bull. Soc. Geol. Fr., 8:327-337.

Laverne, C., and Vivier, G., 1983. Petrographical and chemical study of basement from the Galapagos Spreading Center, Leg 70. In Honnorez, J., Von Herzen, R.P., et al., Init. Repts. DSDP, 70: Washington (U.S. Govt. Printing Office), 375-390.

Mével, C., 1979. Mineralogy and chemistry of secondary phases in low temperature altered basalts from Deep Sea Drilling Project Legs 51, 52 and 53. In Donnelly, T., Francheteau, J., Bryan, W., Robinson, P., Flower, M., Salisbury, M., et al., Init. Repts. DSDP, 51, 52, 53: Washington (U.S. Govt. Printing Office): 1201-1217.

Passaglio, E., 1970. The crystal chemistry of chabazites. Am. Mineral., $55: 1278-1301$. 
Table 5 (continued).

\begin{tabular}{|c|c|c|c|c|c|c|c|c|c|c|c|c|c|c|}
\hline $\begin{array}{l}\text { Core, section: } \\
\text { Interval }(\mathrm{cm}): \\
\text { Piece no.: } \\
\text { Depth (mbsf): } \\
\text { Rock type: } \\
\text { Occurrence: } \\
\text { Analysis no.: }\end{array}$ & $\begin{array}{c}\text { I7R-3 } \\
43-45 \\
4 \\
346.8 \\
\text { BH } \\
\text { Oliv r } \\
\text { M } 37 \\
\end{array}$ & $\begin{array}{c}17 \mathrm{R}-3 \\
43-45 \\
4 \\
346.8 \\
\text { BH } \\
\text { Oliv r } \\
\text { M40 }\end{array}$ & $\begin{array}{c}17 \mathrm{R}-3 \\
43-45 \\
4 \\
346.8 \\
\text { BH } \\
\text { Oliv r } \\
\text { M4I }\end{array}$ & $\begin{array}{c}17 \mathrm{R}-3 \\
43-45 \\
4 \\
346.8 \\
\text { BH } \\
\text { Oliv r } \\
\text { M42 }\end{array}$ & $\begin{array}{c}17 \mathrm{R}-3 \\
43-45 \\
4 \\
346.8 \\
\text { BH } \\
\text { Oliv r } \\
\text { M43 }\end{array}$ & $\begin{array}{l}17 \mathrm{R}-3 \\
43-45 \\
4 \\
346.8 \\
\text { BH } \\
\text { Oliv r } \\
\text { M44 }\end{array}$ & $\begin{array}{c}17 \mathrm{R}-3 \\
43-45 \\
4 \\
346.8 \\
\text { BH } \\
\text { Oliv r } \\
\text { M45 }\end{array}$ & $\begin{array}{c}17 \mathrm{R}-3 \\
43-45 \\
4 \\
346.8 \\
\text { BH } \\
\text { Ves r } \\
\text { M54 }\end{array}$ & $\begin{array}{c}17 \mathrm{R}-3 \\
43-45 \\
4 \\
346.8 \\
\text { BH } \\
\text { Oliv r } \\
\text { M61 }\end{array}$ & $\begin{array}{c}17 \mathrm{R}-3 \\
43-45 \\
4 \\
346.8 \\
\text { BH } \\
\text { Oliv r } \\
\text { M62 }\end{array}$ & $\begin{array}{c}17 \mathrm{R}-3 \\
43-45 \\
4 \\
346.8 \\
\text { BH } \\
\text { Oliv r } \\
\text { M63 }\end{array}$ & $\begin{array}{c}17 \mathrm{R}-3 \\
43-45 \\
4 \\
346.8 \\
\text { BH } \\
\text { Oliv r } \\
\text { M64 } \\
\end{array}$ & $\begin{array}{c}\text { I7R-3 } \\
43-45 \\
4 \\
346.8 \\
\text { BH } \\
\text { Ves r } \\
\text { M97 }\end{array}$ & $\begin{array}{c}17 \mathrm{R}-3 \\
43-45 \\
4 \\
346.8 \\
\text { BH } \\
\text { Ves r } \\
\text { M98 }\end{array}$ \\
\hline $\begin{array}{l}\mathrm{SiO}_{2} \\
\mathrm{Al}_{3} \mathrm{O}_{3} \\
\mathrm{FeO}_{6} \\
\mathrm{MnO} \\
\mathrm{MgO} \\
\mathrm{CaO} \\
\mathrm{Na}_{2} \mathrm{O} \\
\mathrm{K}_{2} \mathrm{O} \\
\mathrm{TiO}_{2} \\
\mathrm{Cr}_{2} \mathrm{O}_{3} \\
\text { Total }\end{array}$ & $\begin{array}{r}50.44 \\
1.68 \\
26.42 \\
0.28 \\
5.38 \\
0.55 \\
0.35 \\
7.83 \\
0.11 \\
0.00 \\
93.04\end{array}$ & $\begin{array}{r}51.65 \\
2.51 \\
26.26 \\
0.00 \\
5.58 \\
0.58 \\
0.56 \\
6.76 \\
0.01 \\
0.00 \\
93.89\end{array}$ & $\begin{array}{r}50.95 \\
3.11 \\
25.57 \\
0.50 \\
5.41 \\
0.63 \\
0.50 \\
7.07 \\
0.03 \\
0.08 \\
93.85\end{array}$ & $\begin{array}{r}50.13 \\
3.99 \\
25.39 \\
0.00 \\
5.11 \\
0.60 \\
0.56 \\
6.88 \\
0.11 \\
0.00 \\
92.77\end{array}$ & $\begin{array}{r}51.30 \\
4.21 \\
24.13 \\
0.14 \\
5.08 \\
0.74 \\
0.60 \\
6.69 \\
0.12 \\
0.00 \\
93.00\end{array}$ & $\begin{array}{r}50.30 \\
3.59 \\
25.26 \\
0.84 \\
5.22 \\
0.60 \\
0.48 \\
6.77 \\
0.04 \\
0.00 \\
93.10\end{array}$ & $\begin{array}{r}52.51 \\
2.60 \\
26.12 \\
0.24 \\
5.57 \\
0.59 \\
0.50 \\
6.73 \\
0.02 \\
0.00 \\
94.88\end{array}$ & $\begin{array}{r}51.77 \\
3.14 \\
25.75 \\
0.00 \\
5.09 \\
0.73 \\
0.45 \\
5.88 \\
0.15 \\
0.01 \\
92.97\end{array}$ & $\begin{array}{r}52.44 \\
1.80 \\
25.62 \\
0.00 \\
5.37 \\
1.04 \\
0.55 \\
5.91 \\
0.03 \\
0.00 \\
92.77\end{array}$ & $\begin{array}{r}52.97 \\
1.88 \\
25.47 \\
0.07 \\
5.24 \\
0.95 \\
0.63 \\
6.05 \\
0.06 \\
0.70 \\
94.03\end{array}$ & $\begin{array}{r}52.54 \\
2.09 \\
23.68 \\
0.20 \\
7.25 \\
0.93 \\
0.64 \\
5.61 \\
0.09 \\
0.00 \\
93.02\end{array}$ & $\begin{array}{r}52.13 \\
2.16 \\
25.81 \\
0.00 \\
5.61 \\
0.75 \\
0.52 \\
6.32 \\
0.01 \\
0.00 \\
93.30\end{array}$ & $\begin{array}{r}50.36 \\
2.23 \\
25.28 \\
0.00 \\
5.43 \\
0.91 \\
0.72 \\
5.09 \\
0.04 \\
1.51 \\
91.56\end{array}$ & $\begin{array}{r}50.56 \\
2.23 \\
25.78 \\
0.00 \\
5.25 \\
0.94 \\
0.64 \\
5.12 \\
0.04 \\
0.00 \\
90.56\end{array}$ \\
\hline $\begin{array}{l}\mathrm{Si} \\
\mathrm{Al}^{\mathrm{IV}} \\
\mathrm{Al}^{\mathrm{vi}} \\
\mathrm{Al} \\
\mathrm{Fe} \\
\mathrm{Mn} \\
\mathrm{Mg} \\
\mathrm{Ca} \\
\mathrm{Na} \\
\mathrm{K} \\
\mathrm{Ti} \\
\mathrm{Cr} \\
\text { Total }\end{array}$ & $\begin{array}{l}3.96 \\
0.15 \\
0.00 \\
0.15 \\
1.73 \\
0.02 \\
0.63 \\
0.05 \\
0.05 \\
0.78 \\
0.01 \\
0.00 \\
7.38\end{array}$ & $\begin{array}{l}3.96 \\
0.23 \\
0.00 \\
0.23 \\
1.68 \\
0.00 \\
0.64 \\
0.05 \\
0.08 \\
0.66 \\
0.00 \\
0.00 \\
7.30\end{array}$ & $\begin{array}{l}3.92 \\
0.28 \\
0.00 \\
0.28 \\
1.64 \\
0.03 \\
0.62 \\
0.05 \\
0.07 \\
0.69 \\
0.00 \\
0.00 \\
7.32\end{array}$ & $\begin{array}{l}3.89 \\
0.36 \\
0.00 \\
0.36 \\
1.65 \\
0.00 \\
0.59 \\
0.05 \\
0.08 \\
0.68 \\
0.01 \\
0.00 \\
7.31\end{array}$ & $\begin{array}{l}3.93 \\
0.38 \\
0.00 \\
0.38 \\
1.54 \\
0.01 \\
0.58 \\
0.06 \\
0.09 \\
0.65 \\
0.01 \\
0.00 \\
7.25\end{array}$ & $\begin{array}{l}3.90 \\
0.33 \\
0.00 \\
0.33 \\
1.64 \\
0.06 \\
0.60 \\
0.05 \\
0.07 \\
0.67 \\
0.00 \\
0.00 \\
7.31\end{array}$ & $\begin{array}{l}3.97 \\
0.23 \\
0.00 \\
0.23 \\
1.65 \\
0.02 \\
0.63 \\
0.05 \\
0.07 \\
0.65 \\
0.00 \\
0.00 \\
7.27\end{array}$ & $\begin{array}{l}3.97 \\
0.28 \\
0.00 \\
0.28 \\
1.65 \\
0.00 \\
0.58 \\
0.06 \\
0.07 \\
0.58 \\
0.01 \\
0.00 \\
7.20\end{array}$ & $\begin{array}{l}4.04 \\
0.16 \\
0.00 \\
0.16 \\
1.65 \\
0.00 \\
0.62 \\
0.09 \\
0.08 \\
0.58 \\
0.00 \\
0.00 \\
7.21\end{array}$ & $\begin{array}{l}4.02 \\
0.17 \\
0.00 \\
0.17 \\
1.62 \\
0.00 \\
0.59 \\
0.08 \\
0.09 \\
0.59 \\
0.00 \\
0.04 \\
7.21\end{array}$ & $\begin{array}{l}3.99 \\
0.19 \\
0.00 \\
0.19 \\
1.50 \\
0.01 \\
0.82 \\
0.08 \\
0.09 \\
0.54 \\
0.00 \\
0.00 \\
7.23\end{array}$ & $\begin{array}{l}4.00 \\
0.20 \\
0.00 \\
0.20 \\
1.66 \\
0.00 \\
0.64 \\
0.06 \\
0.08 \\
0.62 \\
0.00 \\
0.00 \\
7.25\end{array}$ & $\begin{array}{l}3.94 \\
0.21 \\
0.00 \\
0.21 \\
1.65 \\
0.00 \\
0.63 \\
0.08 \\
0.11 \\
0.51 \\
0.00 \\
0.09 \\
7.22\end{array}$ & $\begin{array}{l}3.99 \\
0.21 \\
0.00 \\
0.21 \\
1.70 \\
0.00 \\
0.62 \\
0.08 \\
0.10 \\
0.52 \\
0.00 \\
0.00 \\
7.21\end{array}$ \\
\hline
\end{tabular}

Notes: Formulas calculated on the basis of 22 oxygens. Abbreviations as in Table 3 .

Petersen, N., Eisenach, P., and Bleil, U., 1979. Low temperature alteration of the magnetic minerals in ocean floor basalts. In Talwani, M., Harrison, C.G., and Hayes, D.E. (Eds.), Deep Drilling Results in the Atlantic Ocean: Ocean Crust. Am. Geophys. Union, Washington, 169-209.

Robinson, D., Bevins, R.E., and Rowbothan, G., 1993. The characterization of mafic phyllosilicates in low-grade metabasalts from eastern North Greenland. Am. Mineral., 78:377-390.

Seyfried, W.E., Jr., Mottl, M.J., and Bischoff, J.L., 1978. Chemistry and mineralogy of spilites from the ocean floor: effect of seawater/basalt ratio. Nature, 275:211-213.

Shipboard Scientific Party, 1988. Site 504: Costa Rica Rift. In Becker, K., Sakai, H., et al., Proc. ODP, Init. Repts., 111: College Station, TX (Ocean Drilling Program), 35-251.
1993. Site 504. In Alt, J.C., Kinoshita, H., Stokking, L.B., et al., Proc. ODP, Init. Repts., 148: College Station, TX (Ocean Drilling Program), $27-121$.

Velde, B., 1984. Electron microprobe analysis of clay minerals. Clay Miner., 19:243-247.

Date of initial receipt: 17 August 1994 Date of acceptance: 28 February 1995 Ms 148SR-127 
Table 6. Representative analyses of type 4 phyllosilicate (celadonite and nontronite), Hole 896A.

\begin{tabular}{|c|c|c|c|c|c|c|c|}
\hline Core, section: & $17 R-4$ & $17 R-4$ & $17 \mathrm{R}-4$ & $17 R-4$ & $23 \mathrm{R}-2$ & $23 R-2$ & $23 \mathrm{R}-2$ \\
\hline Interval $(\mathrm{cm})$ : & $15-20$ & $15-20$ & $15-20$ & $15-20$ & $0-6$ & $0-6$ & $0-6$ \\
\hline Piece no.: & $2 \mathrm{C}$ & $2 \mathrm{C}$ & $2 \mathrm{C}$ & $2 \mathrm{C}$ & IA & IA & IA \\
\hline Depth (mbsf): & 348.1 & 348.1 & 348.1 & 348.1 & 393.6 & 393.6 & 393.6 \\
\hline Rock type: & CRHA & CRHA & CRHA & CRHA & CRHA & CRHA & CRHA \\
\hline Occurrence: & Inter & Inter & Oliv $\mathrm{r}$ & Oliv $r$ & Vesicle & Vesicle & Vesicle \\
\hline Analysis no.: & M137 & M139 & M143 & M144 & M67 & M68 & M69 \\
\hline $\mathrm{SiO}_{2}$ & 49.76 & 49.72 & 50.04 & 51.01 & 51.18 & 50.84 & 51.24 \\
\hline $\mathrm{Al}_{2} \mathrm{O}$ & 1.62 & 1.32 & 3.81 & 3.73 & 3.70 & 3.07 & 2.35 \\
\hline $\mathrm{FeO}_{4}$ & 26.53 & 26.76 & 22.71 & 23.99 & 24.50 & 24.67 & 24.04 \\
\hline $\mathrm{MnO}$ & 0.00 & 0.00 & 0.00 & 0.00 & 0.00 & 0.00 & 0.00 \\
\hline $\mathrm{MgO}$ & 4.25 & 3.80 & 5.46 & 5.07 & 5.79 & 5.72 & 6.08 \\
\hline $\mathrm{CaO}$ & 0.49 & 0.40 & 0.94 & 0.99 & 0.69 & 0.66 & 0.52 \\
\hline $\mathrm{Na}_{2} \mathrm{O}$ & 0.12 & 0.15 & 0.20 & 0.17 & 0.63 & 0.59 & 0.52 \\
\hline $\mathrm{K}_{2} \mathrm{O}$ & 8.14 & 8.56 & 6.05 & 6.63 & 5,73 & 6.42 & 7.16 \\
\hline $\mathrm{TiO}_{2}$ & 0.00 & 0.00 & 0.00 & 0.00 & 0.00 & 0.00 & 0.00 \\
\hline $\mathrm{Cr}_{2} \mathrm{O}_{3}$ & 0.00 & 0.00 & 0.00 & 0.00 & 0.00 & 0.00 & 0.00 \\
\hline Total & 90.91 & 90.70 & 89.20 & 91.59 & 92.21 & 91.98 & 91.90 \\
\hline $\mathrm{Si}$ & 4.00 & 4.03 & 3.96 & 3.96 & 3.94 & 3.95 & 3.99 \\
\hline $\mathrm{Al}^{\mathrm{iv}}$ & 0.15 & 0.13 & 0.35 & 0.34 & 0.34 & 0.28 & 0.21 \\
\hline $\mathrm{Al}^{\mathrm{vi}}$ & 0.00 & 0.00 & 0.00 & 0.00 & 0.00 & 0.00 & 0.00 \\
\hline $\mathrm{Al}_{1}$ & 0.15 & 0.13 & 0.35 & 0.34 & 0.34 & 0.28 & 0.21 \\
\hline $\mathrm{Fe}_{1}$ & 1.79 & 1.81 & 1.50 & 1.56 & 1.58 & 1.60 & 1.56 \\
\hline Mn & 0.00 & 0.00 & 0.00 & 0.00 & 0.00 & 0.00 & 0.00 \\
\hline $\mathrm{Ti}$ & 0.00 & 0.00 & 0.00 & 0.00 & 0.00 & 0.00 & 0.00 \\
\hline $\mathrm{Cr}$ & 0.00 & 0.00 & 0.00 & 0.00 & 0.00 & 0.00 & 0.00 \\
\hline $\mathrm{Mg}$ & 0.51 & 0.46 & 0.64 & 0.59 & 0.66 & 0.66 & 0.71 \\
\hline $\mathrm{Ca}$ & 0.04 & 0.03 & 0.08 & 0.08 & 0.06 & 0.06 & 0.04 \\
\hline $\mathrm{Na}$ & 0.02 & 0.02 & 0.03 & 0.03 & 0.09 & 0.09 & 0.08 \\
\hline K & 0.84 & 0.88 & 0.61 & 0.66 & 0.56 & 0.64 & 0.71 \\
\hline Total & 7.35 & 7.36 & 7.18 & 7.21 & 7.22 & 7.27 & 7.30 \\
\hline
\end{tabular}

Notes: Formulas calculated on the basis of 22 oxygens. Abbreviations as in Table 3.

Table 7. Representative analyses of type 5 phyllosilicate (mixture of celadonite-nontronite and saponite), Hole 896A.

\begin{tabular}{|c|c|c|c|c|c|c|c|c|c|c|c|c|c|}
\hline Core, section: & $4 \mathrm{R}-1$ & $4 \mathrm{R}-1$ & $4 \mathrm{R}-\mathrm{I}$ & I7R-3 & $17 R-3$ & $21 R-1$ & $21 \mathrm{R}-1$ & $21 \mathrm{R}-1$ & $21 R-1$ & $21 R-1$ & $25 R-3$ & $25 R-3$ & $25 \mathrm{R}-3$ \\
\hline Interval $(\mathrm{cm})$ : & $37-44$ & $37-44$ & $37-44$ & $43-45$ & $43-45$ & $84-91$ & $84-91$ & $84-91$ & $84-91$ & $84-91$ & $30-34$ & $30-34$ & $30-34$ \\
\hline Piece no.: & 8 & 8 & 8 & 4 & 4 & 14 & 14 & 14 & 14 & 14 & 5 & 5 & 5 \\
\hline Depth (mbsf); & 219.3 & 219.3 & 219.3 & 346.8 & 346.8 & 373.7 & 373.7 & 373.7 & 373.7 & 373.7 & 414.4 & 414.4 & 414.4 \\
\hline Rock type: & $\mathrm{BrH}$ & $\mathrm{BrH}$ & $\mathrm{BrH}$ & $\mathrm{BH}$ & $\mathrm{BH}$ & CRHA & CRHA & CRHA & CRHA & CRHA & CRHA & CRHA & CRHA \\
\hline Occurrence: & Vesicle & Vesicle & Vesicle & Inter & Vesicle & Vesicle & Vesicle & Vesicle & Inter & Inter & Vesicle & Vesicle & Vesicle \\
\hline Analysis no.: & M116 & M117 & MII8 & M109 & M89 & M41 & M43 & M44 & M61 & M65 & M92 & M94 & M95 \\
\hline $\mathrm{SiO}_{2}$ & 43.23 & 43.59 & 45.15 & 50.35 & 44.11 & 46.51 & 40.08 & 46.67 & 44.52 & 46.21 & 47.44 & 46.95 & 46.09 \\
\hline $\mathrm{Al}_{2} \mathrm{O}_{3}$ & 5.79 & 5.96 & 6.03 & 3.39 & 2.71 & 5.22 & 5.69 & 4.97 & 5.25 & 6.04 & 3.32 & 4.65 & 4.23 \\
\hline $\mathrm{FeO}$ & 25.64 & 25.58 & 22.24 & 24.55 & 25.57 & 25.96 & 24.24 & 25.87 & 24.65 & 22.39 & 23.88 & 20.68 & 21.11 \\
\hline $\mathrm{MnO}$ & 0.00 & 0.00 & 0.00 & 0.09 & 0.00 & 0.00 & 0.00 & 0.00 & 0.00 & 0.00 & 0.00 & 0.00 & 0.00 \\
\hline $\mathrm{MgO}$ & 6.83 & 7.02 & 8.18 & 4.38 & 8.85 & 6.18 & 12.75 & 5.91 & 8.68 & 9.92 & 9.78 & 10.61 & 11.22 \\
\hline $\mathrm{CaO}$ & 1.28 & 1.20 & 1.29 & 0.85 & 0.98 & 1.44 & 0.42 & 0.99 & 1.35 & 1.11 & 1.09 & 1.20 & 1.08 \\
\hline $\mathrm{Na}, \mathrm{O}$ & 0.32 & 0.35 & 0.35 & 0.60 & 0.53 & 0.40 & 0.45 & 0.69 & 0.93 & 1.37 & 0.39 & 0.71 & 0.53 \\
\hline $\mathrm{K}, \mathrm{O}$ & 3.75 & 3.69 & 3.25 & 4.82 & 3.90 & 4.52 & 2.62 & 4.88 & 2.77 & 2.37 & 3.80 & 3.73 & 3.63 \\
\hline $\mathrm{TiO}_{2}$ & 0.00 & 0.00 & 0.00 & 0.15 & 0.00 & 0.00 & 0.00 & 0.00 & 0.00 & 0.00 & 0.01 & 0.00 & 0.00 \\
\hline $\mathrm{Cr}_{2} \mathrm{O}_{3}$ & 0.00 & 0.00 & 0.00 & 0.00 & 0.00 & 0.00 & 0.00 & 0.00 & 0.00 & 0.00 & 0.12 & 0.00 & 0.00 \\
\hline Total & 86.84 & 87.39 & 86.49 & 89.19 & 86.65 & 90.22 & 86.25 & 89.99 & 88.13 & 89.41 & 89.83 & 88.52 & 87.89 \\
\hline Si & 3.59 & 3.59 & 3.66 & 4.00 & 3.69 & 3.71 & 3.34 & 3.74 & 3.60 & 3.61 & 3.74 & 3.70 & 3.67 \\
\hline $\mathrm{Al}^{\mathrm{IV}}$ & 0.57 & 0.58 & 0.58 & 0.32 & 0.27 & 0.49 & 0.56 & 0.47 & 0.50 & 0.56 & 0.31 & 0.43 & 0.40 \\
\hline $\mathrm{Al}^{\mathrm{vi}}$ & 0.00 & 0.00 & 0.00 & 0.00 & 0.00 & 0.00 & 0.00 & 0.00 & 0.00 & 0.00 & 0.00 & 0.00 & 0.00 \\
\hline $\mathrm{AI}_{5}$ & 0.57 & 0.58 & 0.58 & 0.32 & 0.27 & 0.49 & 0.56 & 0.47 & 0.50 & 0.56 & 0.31 & 0.43 & 0.40 \\
\hline $\mathrm{Fe}$ & 1.78 & 1.76 & 1.51 & 1.63 & 1.79 & 1.73 & 1.69 & 1.73 & 1.67 & 1.46 & 1.58 & 1.36 & 1.41 \\
\hline $\mathrm{Mn}$ & 0.00 & 0.00 & 0.00 & 0.01 & 0.00 & 0.00 & 0.00 & 0.00 & 0.00 & 0.00 & 0.00 & 0.00 & 0.00 \\
\hline $\mathrm{Mg}$ & 0.85 & 0.86 & 0.99 & 0.52 & 1.10 & 0.73 & 1.58 & 0.71 & 1.05 & 1.16 & 1.15 & 1.25 & 1.33 \\
\hline $\mathrm{Ca}$ & 0.11 & 0.11 & 0.11 & 0.07 & 0.09 & 0.12 & 0.04 & 0.08 & 0.12 & 0.09 & 0.09 & 0.10 & 0.09 \\
\hline $\mathrm{Na}$ & 0.05 & 0.06 & 0.05 & 0.09 & 0.09 & 0.06 & 0.07 & 0.11 & 0.15 & 0.21 & 0.06 & 0.11 & 0.08 \\
\hline $\mathrm{K}$ & 0.40 & 0.39 & 0.34 & 0.49 & 0.42 & 0.46 & 0.28 & 0.50 & 0.29 & 0.24 & 0.38 & 0.38 & 0.37 \\
\hline $\mathrm{Ti}$ & 0.00 & 0.00 & 0.00 & 0.01 & 0.00 & 0.00 & 0.00 & 0.00 & 0.00 & 0.00 & 0.00 & 0.00 & 0.00 \\
\hline $\mathrm{Cr}$ & 0.00 & 0.00 & 0.00 & 0.00 & 0.00 & 0.00 & 0.00 & 0.00 & 0.00 & 0.00 & 0.01 & 0.00 & 0.00 \\
\hline Total & 7.35 & 7.34 & 7.24 & 7.13 & 7.43 & 7.31 & 7.56 & 7.33 & 7.36 & 7.33 & 7.32 & 7.33 & 7.35 \\
\hline
\end{tabular}

Note: Formulas calculated on the basis of 22 oxygens. Abbreviations as in Table 3. 

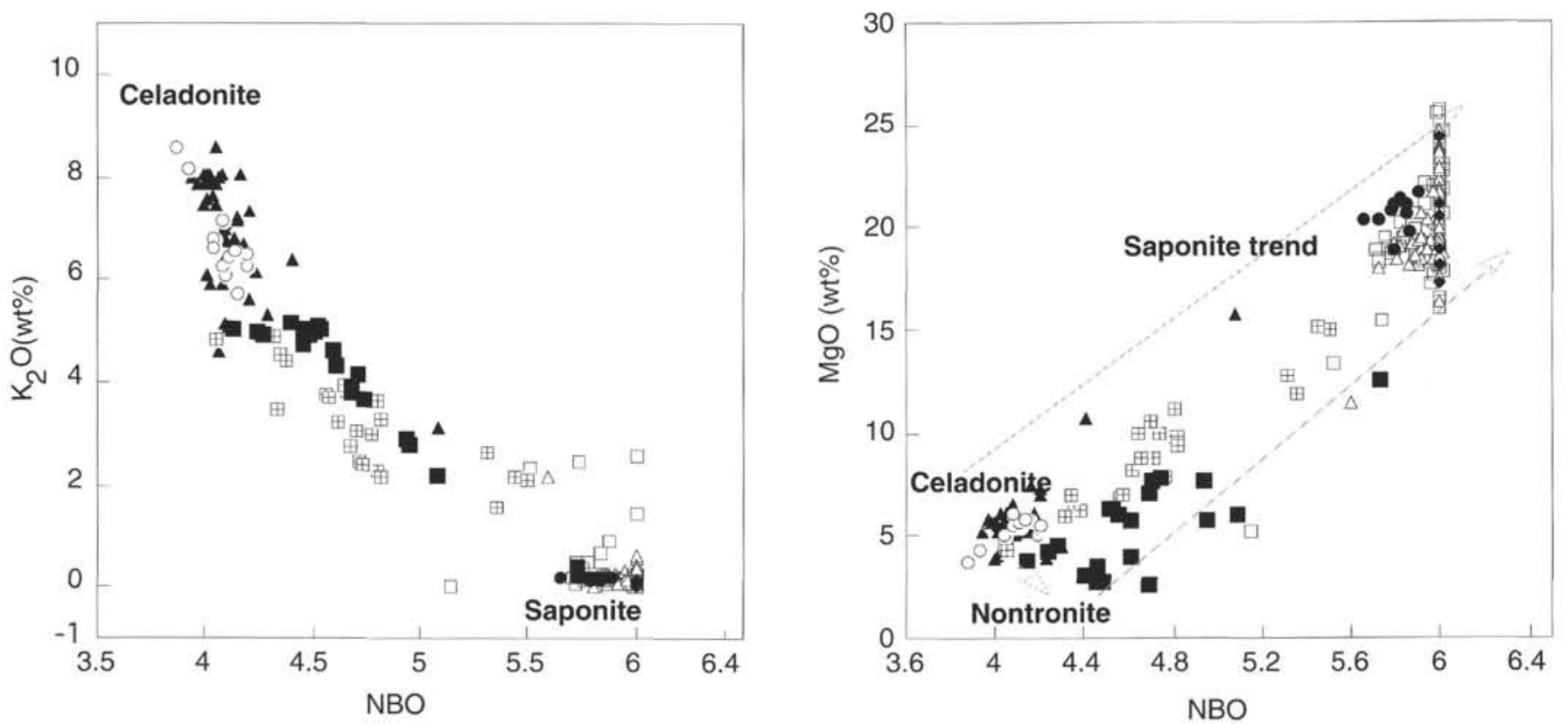

Figure 7. $\mathrm{K}_{2} \mathrm{O}(\mathrm{A})$ and $\mathrm{MgO}$ (B) content vs. number of cations in octahedral sites (NBO) of clay minerals and iddingsite from Hole $896 \mathrm{~A}$ (symbols as in Fig. 5).

Table 8. Representative analyses of type 6 phyllosilicate (mixed-layer chlorite-saponite), Hole 896A.

\begin{tabular}{|c|c|c|c|c|c|c|c|}
\hline Core, section: & $24 R-1$ & $24 \mathrm{R}-1$ & $24 R-1$ & $24 \mathrm{R}-1$ & $24 R-1$ & $24 \mathrm{R}-1$ & $24 \mathrm{R}-1$ \\
\hline Interval $(\mathrm{cm})$ : & $88-92$ & $88-92$ & $88-92$ & $88-92$ & $88-92$ & $88-92$ & $88-92$ \\
\hline \multirow{5}{*}{$\begin{array}{l}\text { Piece no.: } \\
\text { Depth (mbsf): } \\
\text { Rock type: } \\
\text { Occurrence: } \\
\text { Analysis no.: }\end{array}$} & 6 & 6 & 6 & 6 & 6 & 6 & 6 \\
\hline & 402.7 & 402.7 & 402.7 & 402.7 & 402.7 & 402.7 & 402.7 \\
\hline & CRHB,C & CRHB,C & CRHB,C & CRHB,C & CRHB,C & CRHB,C & CRHB,C \\
\hline & Inter & Inter & Inter & Inter & Inter & Inter & Inter \\
\hline & M138 & M142 & M143 & MI44 & M145 & M148 & M149 \\
\hline $\mathrm{SiO}_{2}$ & 35.37 & 34.73 & 34.08 & 35.47 & 33.83 & 40.75 & 39.52 \\
\hline $\mathrm{Al}_{2} \mathrm{O}_{3}$ & 7.07 & 6.97 & 7.79 & 7.17 & 9.16 & 7.86 & 7.70 \\
\hline $\mathrm{FeO}$ & 21.44 & 23.90 & 26.32 & 22.54 & 27.51 & 10.39 & 21.30 \\
\hline $\mathrm{MnO}$ & 0.77 & 0.15 & 0.00 & 0.36 & 0.18 & 0.00 & 0.00 \\
\hline $\mathrm{MgO}$ & 21.08 & 18.85 & 18.11 & 20.56 & 17.25 & 24.38 & 20.48 \\
\hline $\mathrm{CaO}$ & 0.32 & 0.29 & 0.23 & 0.28 & 0.19 & 0.70 & 0.67 \\
\hline $\mathrm{Na}_{2} \mathrm{O}$ & 0.22 & 0.16 & 0.11 & 0.12 & 0.17 & 0.19 & 0.16 \\
\hline $\mathrm{K} . \mathrm{O}$ & 0.13 & 0.11 & 0.07 & 0.12 & 0.04 & 0.11 & 0.09 \\
\hline $\mathrm{TiO}_{2}$ & 0.03 & 0.02 & 0.02 & 0.01 & 0.01 & 0.00 & 0.10 \\
\hline $\mathrm{Cr} . \mathrm{O}_{3}$ & 0.00 & 0.03 & 0.75 & 0.00 & 0.00 & 0.00 & 0.32 \\
\hline Total & 86.44 & 85.20 & 87.49 & 86.62 & 88.32 & 84.37 & 90.34 \\
\hline $\mathrm{Si}$ & 2.91 & 2.93 & 2.83 & 2.91 & 2.80 & 3.17 & 3.05 \\
\hline $\mathrm{Al}^{\mathrm{IV}}$ & 0.68 & 0.69 & 0.76 & 0.69 & 0.89 & 0.72 & 0.70 \\
\hline $\mathrm{Fe}$ & 0.21 & 0.38 & 0.41 & 0.40 & 0.31 & 0.11 & 0.25 \\
\hline $\mathrm{Al}^{\mathrm{vi}}$ & 0.00 & 0.00 & 0.00 & 0.00 & 0.00 & 0.00 & 0.00 \\
\hline $\mathrm{Al}_{\text {, }}$ & 0.68 & 0.69 & 0.76 & 0.69 & 0.89 & 0.72 & 0.70 \\
\hline $\mathrm{Fe}_{\text {, }}$ & 1.26 & 1.30 & 1.42 & 1.15 & 1.59 & 0.57 & 1.13 \\
\hline $\mathrm{Mn}$ & 0.05 & 0.01 & 0.00 & 0.02 & 0.01 & 0.00 & 0.00 \\
\hline $\mathrm{Mg}$ & 1.68 & 2.37 & 2.25 & 2.52 & 2.12 & 2.83 & 2.36 \\
\hline $\mathrm{Ti}^{\circ}$ & 0.00 & 0.00 & 0.00 & 0.00 & 0.00 & 0.00 & 0.01 \\
\hline $\mathrm{Cr}$ & 0.00 & 0.00 & 0.05 & 0.00 & 0.00 & 0.00 & 0.02 \\
\hline $\mathrm{Mg}$ & 0.90 & 0.68 & 0.72 & 0.69 & 0.73 & 0.40 & $0.5 i$ \\
\hline $\mathrm{Ca}$ & 0.03 & 0.03 & 0.02 & 0.02 & 0.02 & 0.06 & 0.06 \\
\hline $\mathrm{Na}$ & 0.03 & 0.03 & 0.02 & 0.02 & 0.03 & 0.03 & 0.02 \\
\hline K & 0.01 & 0.01 & 0.01 & 0.01 & 0.00 & 0.01 & 0.01 \\
\hline Total & 7.77 & 7.74 & 7.77 & 7.75 & 7.77 & 7.49 & 7.60 \\
\hline $\mathrm{T}\left({ }^{\circ} \mathrm{C}\right)$ & 48 & 49 & 61 & 50 & 82 & 54 & 51 \\
\hline$x$ & 0.59 & 0.79 & 0.77 & 0.82 & 0.79 & 0.83 & 0.41 \\
\hline
\end{tabular}

Notes: Formulas calculated on the basis of 22 oxygens. $X=$ percentage of pure chlorite (see text for explanation). Abbreviations as in Table 3.
Table 9. Representative analyses of type 7 phyllosilicate (Fe-rich saponite or mixture of saponite and Fe-oxide), Hole 896A.

\begin{tabular}{|c|c|c|c|c|c|}
\hline $\begin{array}{l}\text { Core, section: } \\
\text { Interval }(\mathrm{cm}): \\
\text { Piece no.: } \\
\text { Depth (mbsf): } \\
\text { Rock type: } \\
\text { Occurrence: } \\
\text { Analysis no,: }\end{array}$ & $\begin{array}{c}25 \mathrm{R}-3 \\
30-34 \\
5 \\
414.4 \\
\text { CRHC } \\
\text { Inter } \\
\text { M } 129\end{array}$ & $\begin{array}{c}25 \mathrm{R}-3 \\
30-34 \\
5 \\
414.4 \\
\text { CRHC } \\
\text { Inter } \\
\text { M130 }\end{array}$ & $\begin{array}{c}25 R-3 \\
30-34 \\
5 \\
414.4 \\
\text { CRHC } \\
\text { Inter } \\
\text { M131 }\end{array}$ & $\begin{array}{c}25 \mathrm{R}-3 \\
30-34 \\
5 \\
414.4 \\
\text { CRHC } \\
\text { Inter } \\
\text { M133 }\end{array}$ & $\begin{array}{c}25 \mathrm{R}-3 \\
30-34 \\
5 \\
414.4 \\
\text { CRHC } \\
\text { Inter } \\
\text { MI34 }\end{array}$ \\
\hline $\begin{array}{l}\mathrm{SiO}_{2} \\
\mathrm{Al}_{2} \mathrm{O}_{2} \\
\mathrm{FeO}_{1} \\
\mathrm{MnO} \\
\mathrm{MgO} \\
\mathrm{CaO} \\
\mathrm{Na}_{2} \mathrm{O} \\
\mathrm{K}_{2} \mathrm{O} \\
\mathrm{TiO}_{2} \\
\mathrm{Cr}_{2} \mathrm{O}_{3} \\
\text { Total }\end{array}$ & $\begin{array}{r}44.85 \\
4.37 \\
10.19 \\
0.00 \\
21.05 \\
1.07 \\
0.62 \\
0.16 \\
0.00 \\
0.00 \\
82.31\end{array}$ & $\begin{array}{r}46.98 \\
4.54 \\
9.20 \\
0.00 \\
20.42 \\
1.07 \\
0.52 \\
0.17 \\
0.00 \\
0.00 \\
82.91\end{array}$ & $\begin{array}{r}44.60 \\
4.46 \\
11.47 \\
0.00 \\
21.36 \\
1.17 \\
0.71 \\
0.18 \\
0.00 \\
0.00 \\
83.95\end{array}$ & $\begin{array}{r}45.05 \\
4.58 \\
10.10 \\
0.00 \\
20.87 \\
1.05 \\
0.59 \\
0.19 \\
0.00 \\
0.00 \\
82.44\end{array}$ & $\begin{array}{r}40.45 \\
5.15 \\
14.83 \\
0.00 \\
19.82 \\
1.46 \\
0.61 \\
0.19 \\
0.00 \\
0.00 \\
82.49\end{array}$ \\
\hline $\begin{array}{l}\mathrm{Si} \\
\mathrm{Al}^{\mathrm{v}} \\
\mathrm{Al}^{\mathrm{vi}} \\
\mathrm{Al} \\
\mathrm{Fe}_{\mathrm{i}} \\
\mathrm{Mn} \\
\mathrm{Mg} \\
\mathrm{Ca} \\
\mathrm{Na} \\
\mathrm{K} \\
\mathrm{Ti} \\
\mathrm{Cr} \\
\mathrm{Total}\end{array}$ & $\begin{array}{r}6.98 \\
0.80 \\
0.00 \\
0.80 \\
1.66 \\
0.00 \\
4.88 \\
0.18 \\
0.19 \\
0.03 \\
0.00 \\
0.00 \\
14.72\end{array}$ & $\begin{array}{r}7.19 \\
0.81 \\
0.01 \\
0.82 \\
1.47 \\
0.00 \\
4.66 \\
0.18 \\
0.16 \\
0.03 \\
0.00 \\
0.00 \\
14.50\end{array}$ & $\begin{array}{r}6.86 \\
0.81 \\
0.00 \\
0.81 \\
1.84 \\
0.00 \\
4.90 \\
0.19 \\
0.21 \\
0.04 \\
0.00 \\
0.00 \\
14.85\end{array}$ & $\begin{array}{r}7.00 \\
0.84 \\
0.00 \\
0.84 \\
1.64 \\
0.00 \\
4.83 \\
0.18 \\
0.18 \\
0.04 \\
0.00 \\
0.00 \\
14.69\end{array}$ & $\begin{array}{r}6.48 \\
0.97 \\
0.00 \\
0.97 \\
2.48 \\
0.00 \\
4.73 \\
0.25 \\
0.19 \\
0.04 \\
0.00 \\
0.00 \\
15.15\end{array}$ \\
\hline
\end{tabular}

Notes: Formulas calculated on the basis of 22 oxygens. Abbreviations as in Table 3. 

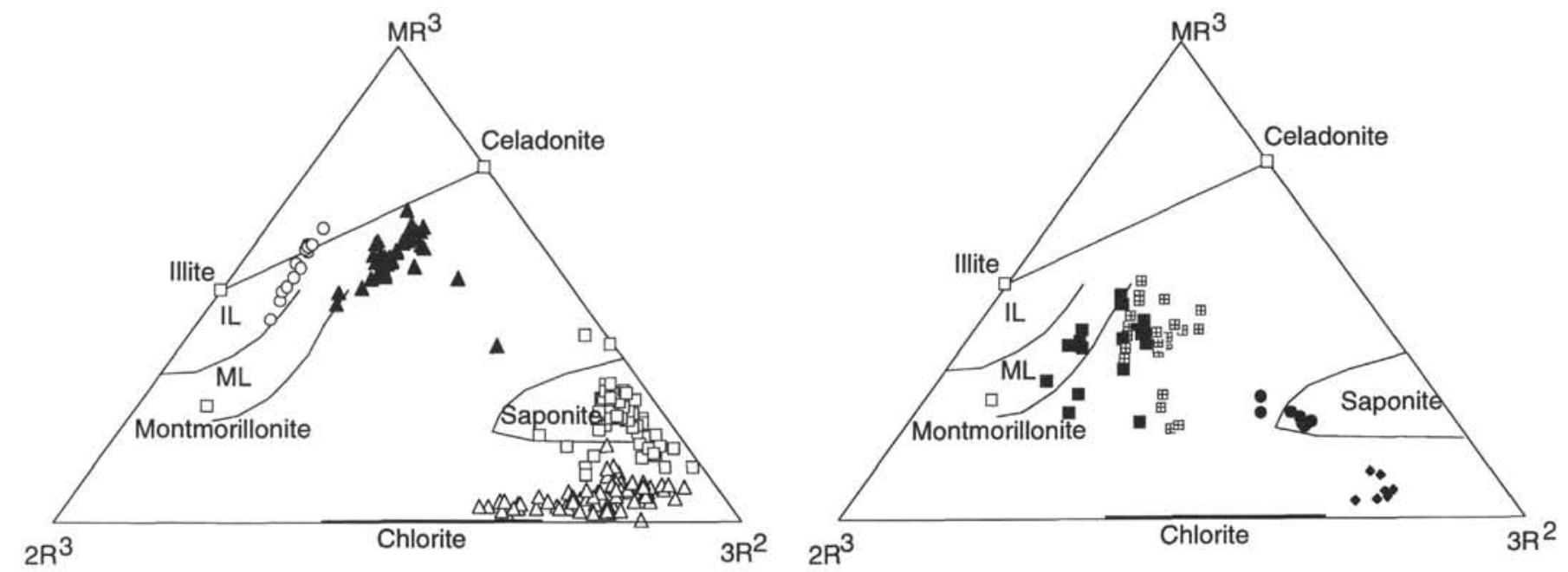

Figure 8. Compositions of Hole 896A clay minerals and iddingsite in the Velde's (1984) diagram (symbols as in Fig. 5$) \cdot \mathrm{MR}^{3}=\mathrm{Na}+\mathrm{K}+2 \mathrm{Ca} \cdot 2 \mathrm{R}^{3}=\left(\mathrm{Al}+\mathrm{Fe}^{3+}\right.$ $-\mathrm{MR} 3) / 2.3 \mathrm{R}^{2}=\mathrm{Fe}^{2+}+\mathrm{Mn}+\mathrm{Mg} / 3$.

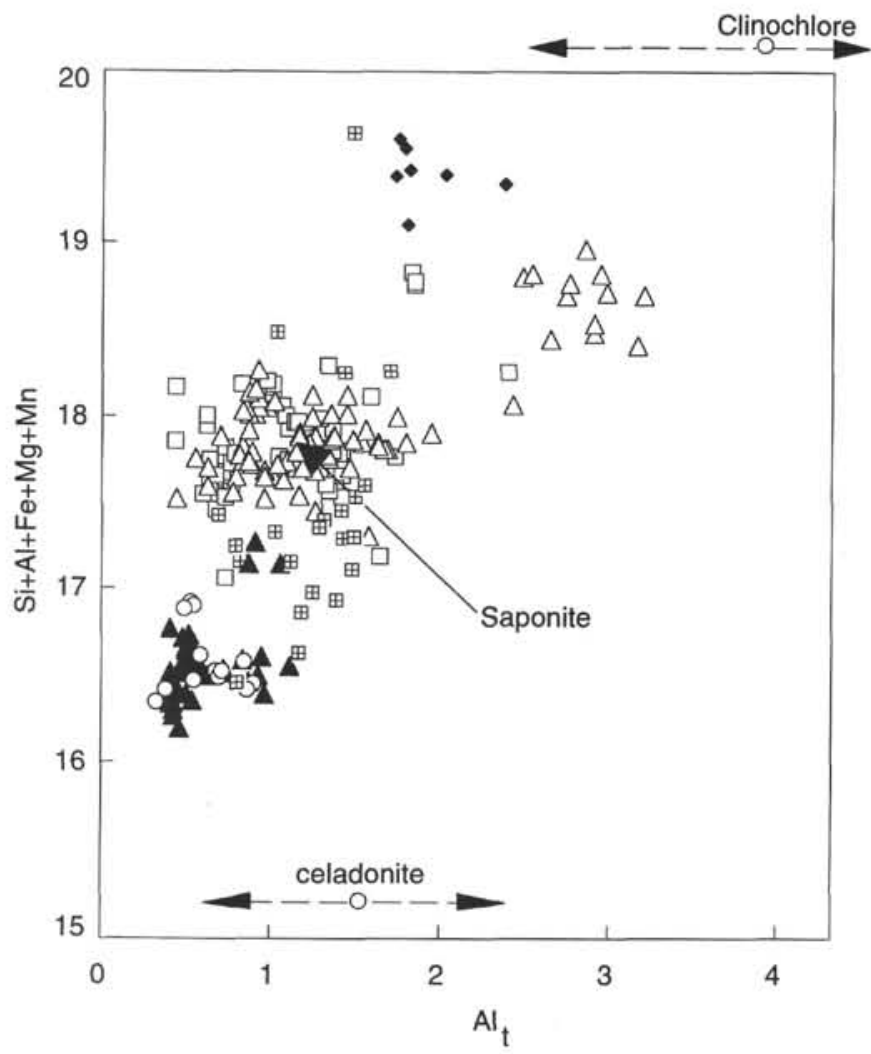

Figure $9 . \mathrm{Si}+\mathrm{Al}_{1}+\mathrm{Fe}+\mathrm{Mg}+\mathrm{Mn}$ vs. $\mathrm{Al}_{1}$ (calculated on the basis of 28 oxygens) in clay minerals and iddingsite from Hole $896 \mathrm{~A}$, after Robinson (1993); symbols as in Figure 5. 
Table 10. Representative analyses of iddingsite (mixtures of Fe-oxyhydroxides, celadonite, and saponite), Hole 896A.

\begin{tabular}{|c|c|c|c|c|c|c|c|c|c|c|c|c|}
\hline $\begin{array}{l}\text { Core, section: } \\
\text { Interval }(\mathrm{cm}): \\
\text { Piece no.: } \\
\text { Depth (mbsf): } \\
\text { Rock type: } \\
\text { Occurrence: } \\
\text { Analysis no.: }\end{array}$ & $\begin{array}{l}17 \mathrm{R}-3 \\
43-45 \\
4 \mathrm{~B} \\
346.8 \\
\text { BH } \\
\text { Oliv r } \\
\text { M99 } \\
\end{array}$ & $\begin{array}{c}17 \mathrm{R}-3 \\
43-45 \\
4 \mathrm{~B} \\
346.8 \\
\text { BH } \\
\text { Oliv r } \\
\text { Mio4 }\end{array}$ & $\begin{array}{c}17 \mathrm{R}-4 \\
15-20 \\
2 \mathrm{C} \\
348.1 \\
\text { BH } \\
\text { Oliv r } \\
\text { M105 }\end{array}$ & $\begin{array}{c}17 \mathrm{R}-4 \\
15-20 \\
2 \mathrm{C} \\
348.1 \\
\text { BH } \\
\text { Vesicle } \\
\text { M133 }\end{array}$ & $\begin{array}{c}17 \mathrm{R}-4 \\
15-20 \\
2 \mathrm{C} \\
348.1 \\
\mathrm{BH} \\
\text { Inter } \\
\text { M145 }\end{array}$ & $\begin{array}{c}17 \mathrm{R}-4 \\
15-20 \\
2 \mathrm{C} \\
348.1 \\
\mathrm{BH} \\
\text { Inter } \\
\mathrm{M} 146\end{array}$ & $\begin{array}{c}17 \mathrm{R}-4 \\
15-20 \\
2 \mathrm{C} \\
348.1 \\
\mathrm{BH} \\
\text { Inter } \\
\mathrm{M} 147\end{array}$ & $\begin{array}{c}17 \mathrm{R}-4 \\
15-20 \\
2 \mathrm{C} \\
348.1 \\
\mathrm{BH} \\
\text { Inter } \\
\mathrm{M} 148\end{array}$ & $\begin{array}{l}17 \mathrm{R}-4 \\
15-20 \\
2 \mathrm{C} \\
348.1 \\
\text { CRHB } \\
\text { Vesicle } \\
\text { MI50 }\end{array}$ & $\begin{array}{c}23 R-1 \\
0-6 \\
\text { IA } \\
393.6 \\
\text { CRHA,B } \\
\text { Inter } \\
\text { M74 }\end{array}$ & $\begin{array}{c}25 \mathrm{R}-3 \\
30-34 \\
5 \\
414.4 \\
\text { CRHB } \\
\text { Inter } \\
\text { M114 } \\
\end{array}$ & $\begin{array}{c}25 \mathrm{R}-3 \\
30-34 \\
5 \\
414.4 \\
\text { CRHB } \\
\text { Inter } \\
\text { M115 }\end{array}$ \\
\hline $\begin{array}{l}\mathrm{SiO}_{2} \\
\mathrm{Al}_{2} \mathrm{O}_{3} \\
\mathrm{FeO}_{4} \\
\mathrm{MnO} \\
\mathrm{MgO} \\
\mathrm{CaO} \\
\mathrm{Na}_{2} \mathrm{O} \\
\mathrm{K}_{2} \mathrm{O} \\
\mathrm{TiO}_{2} \\
\mathrm{Cr}_{2} \mathrm{O}_{3} \\
\text { Total }\end{array}$ & $\begin{array}{r}46.03 \\
2.22 \\
32.48 \\
0.06 \\
4.57 \\
0.89 \\
0.58 \\
4.97 \\
0.14 \\
0.50 \\
92.44\end{array}$ & $\begin{array}{r}47.25 \\
2.26 \\
32.88 \\
0.08 \\
4.38 \\
0.87 \\
0.63 \\
5.01 \\
0.13 \\
0.19 \\
93.66\end{array}$ & $\begin{array}{r}48.10 \\
2.35 \\
30.86 \\
0.00 \\
3.89 \\
0.91 \\
0.53 \\
5.05 \\
0.14 \\
0.08 \\
91.90\end{array}$ & $\begin{array}{r}34.52 \\
2.85 \\
39.04 \\
0.00 \\
5.87 \\
0.92 \\
0.17 \\
2.78 \\
0.00 \\
0.00 \\
86.14\end{array}$ & $\begin{array}{r}39.12 \\
3.33 \\
35.93 \\
0.00 \\
3.51 \\
0.75 \\
0.09 \\
4.89 \\
0.00 \\
0.00 \\
87.62\end{array}$ & $\begin{array}{r}33.41 \\
3.38 \\
41.96 \\
0.00 \\
2.71 \\
0.74 \\
0.11 \\
3.81 \\
0.00 \\
0.00 \\
86.11\end{array}$ & $\begin{array}{r}38.03 \\
3.04 \\
37.78 \\
0.00 \\
2.98 \\
0.62 \\
0.10 \\
5.05 \\
0.00 \\
0.00 \\
87.62\end{array}$ & $\begin{array}{r}37.04 \\
3.21 \\
38.80 \\
0.00 \\
2.84 \\
0.71 \\
0.15 \\
4.95 \\
0.00 \\
0.00 \\
87.70\end{array}$ & $\begin{array}{r}38.76 \\
3.11 \\
36.82 \\
0.00 \\
3.11 \\
0.70 \\
0.27 \\
5.20 \\
0.00 \\
0.00 \\
87.97\end{array}$ & $\begin{array}{r}36.30 \\
2.87 \\
38.34 \\
0.00 \\
4.05 \\
0.71 \\
0.48 \\
4.38 \\
0.00 \\
0.00 \\
87.14\end{array}$ & $\begin{array}{r}41.18 \\
1.65 \\
30.32 \\
0.00 \\
6.36 \\
0.69 \\
0.16 \\
5.12 \\
0.00 \\
0.00 \\
85.48\end{array}$ & $\begin{array}{r}36.67 \\
2.39 \\
33.46 \\
0.00 \\
7.74 \\
0.98 \\
0.49 \\
2.94 \\
0.00 \\
0.00 \\
84.66\end{array}$ \\
\hline Type & $8 a$ & $8 a$ & $8 a$ & $8 a$ & $8 a$ & $8 \mathrm{a}$ & $8 a$ & $8 \mathrm{a}$ & $8 a$ & $8 a$ & $8 a$ & $8 a$ \\
\hline
\end{tabular}

Table 10 (continued).

\begin{tabular}{|c|c|c|c|c|c|c|c|c|c|c|c|}
\hline $\begin{array}{l}\text { Core, section: } \\
\text { Interval (cm): } \\
\text { Piece no.: } \\
\text { Depth (mbsf): } \\
\text { Rock type: } \\
\text { Occurrence: } \\
\text { Analysis no.: }\end{array}$ & $\begin{array}{c}25 \mathrm{R}-3 \\
30-34 \\
5 \\
414.4 \\
\text { CRHB } \\
\text { Inter } \\
\text { MI16 }\end{array}$ & $\begin{array}{c}25 \mathrm{R}-3 \\
30-34 \\
5 \\
414.4 \\
\text { CRHB } \\
\text { Inter } \\
\text { M119 }\end{array}$ & $\begin{array}{c}25 \mathrm{R}-3 \\
30-34 \\
5 \\
414.4 \\
\text { CRHB } \\
\text { Inter } \\
\text { M120 }\end{array}$ & $\begin{array}{c}25 R-3 \\
30-34 \\
5 \\
414.4 \\
\text { CRHB } \\
\text { Inter } \\
\text { MI21 }\end{array}$ & $\begin{array}{c}17 \mathrm{R}-4 \\
15-20 \\
2 \mathrm{C} \\
348.1 \\
\text { CRHB } \\
\text { Vesicle } \\
\text { MI32 }\end{array}$ & $\begin{array}{c}17 \mathrm{R}-4 \\
15-20 \\
2 \mathrm{C} \\
348.1 \\
\text { CRHB } \\
\text { Vesicle } \\
\text { M135 }\end{array}$ & $\begin{array}{l}17 \mathrm{R}-4 \\
15-20 \\
2 \mathrm{C} \\
348.1 \\
\text { CRHA } \\
\text { Oliv r } \\
\text { MI53 }\end{array}$ & $\begin{array}{l}17 R-4 \\
15-20 \\
2 \mathrm{C} \\
348.1 \\
\text { CRHA } \\
\text { Oliv r } \\
\text { Mi6i }\end{array}$ & $\begin{array}{c}23 R-2 \\
0-6 \\
\text { IA } \\
393.6 \\
\text { CRHC } \\
\text { Inter } \\
\text { M19 }\end{array}$ & $\begin{array}{c}21 \mathrm{R}-1 \\
84-91 \\
14 \\
373.7 \\
\text { CRHC } \\
\text { Oliv r } \\
\text { M20 }\end{array}$ & $\begin{array}{c}21 \mathrm{R}-1 \\
84-91 \\
14 \\
373.7 \\
\text { CRHC } \\
\text { Inter } \\
\text { M19 }\end{array}$ \\
\hline $\begin{array}{l}\mathrm{SiO}_{2} \\
\mathrm{Al}_{2} \mathrm{O}_{3} \\
\mathrm{FeO}_{1} \\
\mathrm{MnO} \\
\mathrm{MgO} \\
\mathrm{CaO} \\
\mathrm{Na}_{2} \mathrm{O} \\
\mathrm{K}_{2} \mathrm{O} \\
\mathrm{TiO}_{2} \\
\mathrm{Cr}_{2} \mathrm{O}_{3} \\
\mathrm{Total}^{2}\end{array}$ & $\begin{array}{r}40.30 \\
1.93 \\
29.82 \\
0.00 \\
7.71 \\
0.85 \\
0.41 \\
4.15 \\
0.00 \\
0.00 \\
85.16\end{array}$ & $\begin{array}{r}40.73 \\
2.30 \\
29.81 \\
0.00 \\
7.92 \\
0.96 \\
0.41 \\
3.72 \\
0.00 \\
0.00 \\
85.85\end{array}$ & $\begin{array}{r}40.20 \\
1.63 \\
31.03 \\
0.00 \\
6.08 \\
0.66 \\
0.10 \\
5.09 \\
0.00 \\
0.00 \\
84.81\end{array}$ & $\begin{array}{r}38.53 \\
1.60 \\
32.06 \\
0.00 \\
5.79 \\
0.64 \\
0.11 \\
4.67 \\
0.00 \\
0.00 \\
83.39\end{array}$ & $\begin{array}{r}22.42 \\
2.98 \\
51.34 \\
0.00 \\
6.58 \\
0.93 \\
0.10 \\
0.62 \\
0.00 \\
0.00 \\
84.96\end{array}$ & $\begin{array}{r}27.55 \\
3.21 \\
45.90 \\
0.00 \\
6.25 \\
0.92 \\
0.08 \\
1.53 \\
0.00 \\
0.00 \\
85.46\end{array}$ & $\begin{array}{r}17.09 \\
3.63 \\
52.98 \\
0.00 \\
5.41 \\
0.91 \\
0.35 \\
0.20 \\
0.00 \\
0.00 \\
80.56\end{array}$ & $\begin{array}{r}12.98 \\
3.60 \\
57.23 \\
0.00 \\
2.77 \\
0.88 \\
0.25 \\
0.17 \\
0.00 \\
0.00 \\
77.88\end{array}$ & $\begin{array}{r}36.72 \\
3.67 \\
23.93 \\
0.08 \\
15.75 \\
1.19 \\
0.70 \\
0.09 \\
0.01 \\
0.00 \\
82.14\end{array}$ & $\begin{array}{r}21.28 \\
2.27 \\
44.68 \\
0.10 \\
10.78 \\
0.90 \\
0.51 \\
0.06 \\
0.01 \\
0.01 \\
80.60\end{array}$ & $\begin{array}{r}25.21 \\
2.31 \\
40.47 \\
0.34 \\
10.74 \\
0.74 \\
0.59 \\
0.08 \\
0.00 \\
0.02 \\
80.49\end{array}$ \\
\hline Type & $8 \mathrm{a}$ & $8 \mathrm{a}$ & $8 \mathrm{a}$ & $8 \mathrm{a}$ & $8 b$ & $8 b$ & $8 b$ & $8 \mathrm{~b}$ & $8 b$ & $8 b$ & $8 b$ \\
\hline
\end{tabular}

Table 10 (continued).

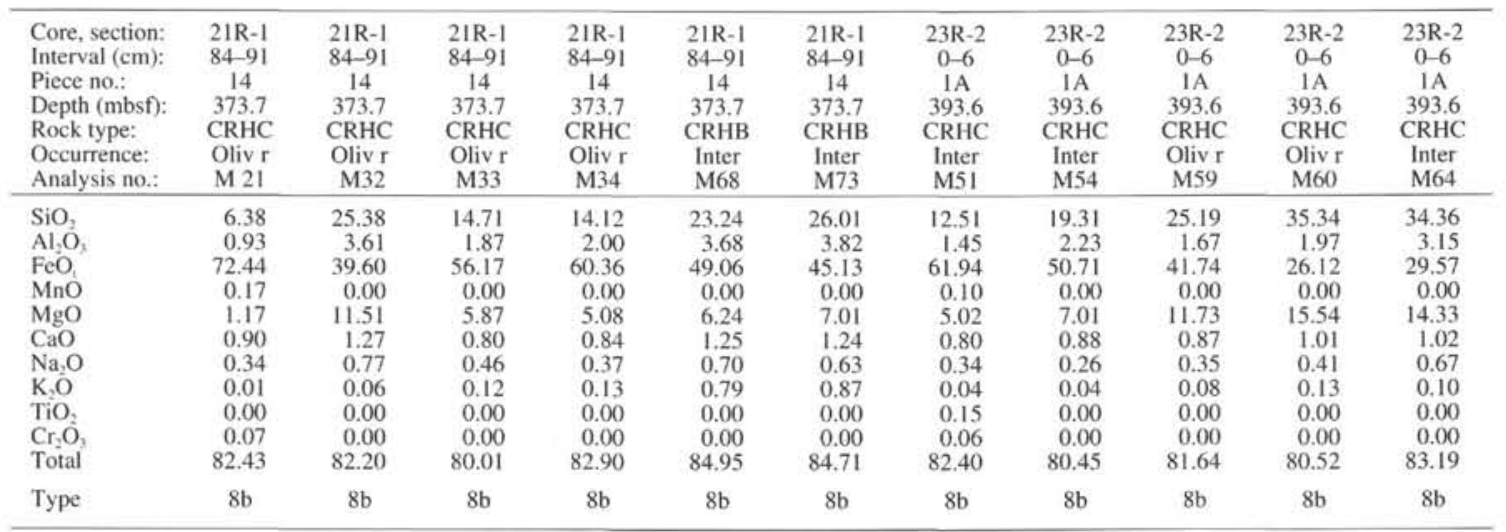


Table 10 (continued).

\begin{tabular}{|c|c|c|c|c|c|c|c|c|c|c|c|}
\hline $\begin{array}{l}\text { Core, section: } \\
\text { Interval }(\mathrm{cm}) \\
\text { Piece no.: } \\
\text { Depth (mbsf): } \\
\text { Rock type: } \\
\text { Occurrence: } \\
\text { Analysis no.: }\end{array}$ & $\begin{array}{c}23 \mathrm{R}-2 \\
0-6 \\
1 \mathrm{~A} \\
393.6 \\
\text { CRHB } \\
\text { Vesicle } \\
\text { M82 }\end{array}$ & $\begin{array}{c}23 \mathrm{R}-2 \\
0-6 \\
\text { IA } \\
393.6 \\
\text { CRHB } \\
\text { Vesicle } \\
\text { M83 }\end{array}$ & $\begin{array}{c}23 \mathrm{R}-2 \\
0-6 \\
1 \mathrm{~A} \\
393.6 \\
\text { CRHB } \\
\text { Vesicle } \\
\text { M84 }\end{array}$ & $\begin{array}{c}23 R-2 \\
0-6 \\
1 \mathrm{~A} \\
393.6 \\
\text { CRHB } \\
\text { Vesicle } \\
\text { M90 }\end{array}$ & $\begin{array}{c}23 R-2 \\
0-6 \\
\text { IA } \\
393.6 \\
\text { CRHC } \\
\text { Inter } \\
\text { MI7 }\end{array}$ & $\begin{array}{c}23 \mathrm{R}-2 \\
0-6 \\
1 \mathrm{~A} \\
393.6 \\
\text { CRHC } \\
\text { Inter } \\
\text { M21 }\end{array}$ & $\begin{array}{c}23 \mathrm{R}-2 \\
0-6 \\
1 \mathrm{~A} \\
393.6 \\
\text { CRHC } \\
\text { Oliv r } \\
\text { M38 }\end{array}$ & $\begin{array}{c}23 \mathrm{R}-2 \\
0-6 \\
1 \mathrm{~A} \\
393.6 \\
\text { CRHC } \\
\text { Oliv r } \\
\text { M61 }\end{array}$ & $\begin{array}{c}23 \mathrm{R}-2 \\
0-6 \\
\text { IA } \\
393.6 \\
\text { CRHC } \\
\text { Oliv r } \\
\text { M62 }\end{array}$ & $\begin{array}{c}23 \mathrm{R}-2 \\
0-6 \\
\text { IA } \\
393.6 \\
\text { CRHB } \\
\text { Ves r } \\
\text { M93 }\end{array}$ & $\begin{array}{c}23 \mathrm{R}-2 \\
0-6 \\
1 \mathrm{~A} \\
393.6 \\
\text { CRHB } \\
\text { Ves r } \\
\text { M94 }\end{array}$ \\
\hline $\begin{array}{l}\mathrm{SiO}_{2} \\
\mathrm{Al}_{2} \mathrm{O}_{3} \\
\mathrm{FeO}_{1} \\
\mathrm{MnO} \\
\mathrm{MgO} \\
\mathrm{CaO} \\
\mathrm{Na}_{2} \mathrm{O} \\
\mathrm{K}_{2} \mathrm{O} \\
\mathrm{TiO}_{2} \\
\mathrm{Cr}_{2} \mathrm{O}_{3} \\
\mathrm{Total}_{3}\end{array}$ & $\begin{array}{r}22.98 \\
2.42 \\
51.40 \\
0.00 \\
9.39 \\
0.79 \\
0.69 \\
0.09 \\
0.00 \\
0.00 \\
87.76\end{array}$ & $\begin{array}{r}26.68 \\
3.38 \\
43.34 \\
0.00 \\
11.41 \\
0.99 \\
0.99 \\
0.12 \\
0.00 \\
0.00 \\
86.91\end{array}$ & $\begin{array}{r}34.22 \\
3.81 \\
32.01 \\
0.00 \\
13.99 \\
0.96 \\
1.16 \\
0.13 \\
0.00 \\
0.00 \\
86.27\end{array}$ & $\begin{array}{r}17.45 \\
2.03 \\
60.64 \\
0.00 \\
6.94 \\
0.68 \\
0.64 \\
0.08 \\
0.00 \\
0.00 \\
88.46\end{array}$ & $\begin{array}{r}37.03 \\
3.70 \\
26.81 \\
0.19 \\
15.63 \\
1.31 \\
0.78 \\
0.11 \\
0.00 \\
0.01 \\
85.56\end{array}$ & $\begin{array}{r}32.53 \\
3.51 \\
33.10 \\
0.16 \\
13.85 \\
1.18 \\
0.61 \\
0.12 \\
0.09 \\
0.00 \\
85.13\end{array}$ & $\begin{array}{r}37.49 \\
2.21 \\
24.34 \\
0.05 \\
15.76 \\
1.20 \\
0.47 \\
0.16 \\
0.06 \\
0.08 \\
81.81\end{array}$ & $\begin{array}{r}30.01 \\
1.71 \\
34.34 \\
0.00 \\
13.11 \\
0.85 \\
0.38 \\
0.09 \\
0.00 \\
0.00 \\
80.48\end{array}$ & $\begin{array}{r}26.56 \\
2.95 \\
38.83 \\
0.00 \\
12.08 \\
0.84 \\
0.52 \\
0.07 \\
0.00 \\
0.00 \\
81.86\end{array}$ & $\begin{array}{r}38.26 \\
5.86 \\
28.13 \\
0.00 \\
12.47 \\
0.67 \\
1.05 \\
0.43 \\
0.00 \\
0.00 \\
86.87\end{array}$ & $\begin{array}{r}31.56 \\
4.85 \\
36.58 \\
0.00 \\
10.57 \\
0.92 \\
1.43 \\
0.22 \\
0.00 \\
0.00 \\
86.12\end{array}$ \\
\hline Type & $8 \mathrm{~b}$ & $8 b$ & $8 b$ & $8 b$ & $8 b$ & $8 b$ & $8 \mathrm{~b}$ & $8 b$ & $8 b$ & $8 \mathrm{~b}$ & $8 \mathrm{~b}$ \\
\hline
\end{tabular}

Note: Abbreviations as in Table 3.

Table 11. Representative Ca-carbonate analyses, Hole 896A.

\begin{tabular}{|c|c|c|c|c|c|c|c|}
\hline Core, section: & $4 \mathrm{R}-1$ & $4 \mathrm{R}-1$ & $10 \mathrm{R}-1$ & $23 \mathrm{R}-2$ & $23 \mathrm{R}-2$ & $23 \mathrm{R}-2$ & $24 \mathrm{R}-1$ \\
\hline Interval $(\mathrm{cm})$ : & $37-44$ & $37-44$ & $57-60$ & $0-6$ & $0-6$ & $0-6$ & $88-89$ \\
\hline Piece no.: & 8 & 8 & $8 \mathrm{~A}$ & IA & IA & $1 \mathrm{~A}$ & 6 \\
\hline Depth (mbsf): & 219.3 & 219.3 & 276.9 & 393.6 & 393.6 & 393.6 & 402.7 \\
\hline Occurrence: & Vein & Vein & Vein & Vein & Oliv $\mathrm{t}$ & Vesicle & Oliv c \\
\hline Analysis no.: & M126 & M127 & M184 & $\mathrm{M} 3$ & M29 & M80 & M124 \\
\hline $\mathrm{SiO}_{2}$ & 0.10 & 0.11 & 0.12 & 0.07 & 0.23 & 0.06 & 0.27 \\
\hline $\mathrm{Al}_{2} \mathrm{O}_{3}$ & 0.00 & 0.00 & 0.00 & 0.00 & 0.00 & 0.00 & 0.01 \\
\hline $\mathrm{FeO}$ & 0.00 & 0.00 & 0.00 & 0.10 & 0.21 & 0.04 & 0.17 \\
\hline $\mathrm{MnO}$ & 0.03 & 0.00 & 0.00 & 0.00 & 0.00 & 0.00 & 0.00 \\
\hline $\mathrm{MgO}$ & 0.00 & 0.00 & 0.00 & 0.00 & 0.06 & 2.28 & 0.00 \\
\hline $\mathrm{CaO}$ & 59.08 & 58.26 & 57.21 & 59.69 & 57.19 & 57.69 & 58.77 \\
\hline $\mathrm{Na}_{2} \mathrm{O}$ & 0.02 & 0.00 & 0.00 & 0.03 & 0.01 & 0.01 & 0.02 \\
\hline $\mathrm{K}, \mathrm{O}$ & 0.00 & 0.00 & 0.00 & 0.00 & 0.00 & 0.00 & 0.03 \\
\hline $\mathrm{TiO}$ & 0.00 & 0.00 & 0.00 & 0.00 & 0.00 & 0.00 & 0.00 \\
\hline $\mathrm{Cr}_{2} \mathrm{O}_{3}$ & 0.09 & 0.00 & 0.00 & 0.00 & 0.00 & 0.00 & 0.00 \\
\hline Total & 59.32 & 58.37 & 57.33 & 59.88 & 57.71 & 60.08 & 59.25 \\
\hline
\end{tabular}

Note: Abbreviations as in Table 3.

Table 12. Representative zeolites analyses, Hole 896A.

\begin{tabular}{|c|c|c|c|c|c|c|c|c|c|c|c|}
\hline $\begin{array}{l}\text { Core, section: } \\
\text { Interval }(\mathrm{cm}) \text { : } \\
\text { Piece no.: } \\
\text { Depth (mbsf): } \\
\text { Occurrence: } \\
\text { Type: } \\
\text { Nature: } \\
\text { Analysis no.: }\end{array}$ & $\begin{array}{c}9 \mathrm{R}-2 \\
14-17 \\
2 \\
268.2 \\
\text { Vein } \\
\text { Rad fib } \\
\text { Phill } \\
\text { M120 } \\
\end{array}$ & $\begin{array}{c}9 \mathrm{R}-2 \\
14-17 \\
2 \\
268.2 \\
\text { Vein } \\
\text { Rad fib } \\
\text { Phill } \\
\text { M128 } \\
\end{array}$ & $\begin{array}{c}9 \mathrm{R}-2 \\
14-17 \\
2 \\
268.2 \\
\text { Vein } \\
\text { Rad fib } \\
\text { Phill } \\
\text { M129 } \\
\end{array}$ & $\begin{array}{c}\text { 10R-1 } \\
57-60 \\
8 \mathrm{~A} \\
276.9 \\
\text { Vein } \\
\text { Rad fib } \\
\text { Phill } \\
\text { M168 } \\
\end{array}$ & $\begin{array}{c}10 R-1 \\
57-60 \\
8 \mathrm{~A} \\
276.9 \\
\text { Vein } \\
\text { Rad fib } \\
\text { Phill } \\
\text { M171 } \\
\end{array}$ & $\begin{array}{c}\text { 10R-1 } \\
57-60 \\
8 \mathrm{~A} \\
276.9 \\
\text { Vein } \\
\text { Rad fib } \\
\text { Phill } \\
\text { M172 } \\
\end{array}$ & $\begin{array}{c}28 \mathrm{R}-1 \\
107-108 \\
18 \mathrm{~B} \\
440.9 \\
\text { Vesicle } \\
\text { Massive } \\
\text { Chab } \\
\text { M31 } \\
\end{array}$ & $\begin{array}{c}28 \mathrm{R}-1 \\
107-108 \\
18 \mathrm{~B} \\
440.9 \\
\text { Vesicle } \\
\text { Massive } \\
\text { Chab } \\
\text { M32 }\end{array}$ & $\begin{array}{c}28 \mathrm{R}-1 \\
107-108 \\
18 \mathrm{~B} \\
440.9 \\
\text { Vesicle } \\
\text { Massive } \\
\text { Chab } \\
\text { M34 } \\
\end{array}$ & $\begin{array}{c}28 \mathrm{R}-1 \\
107-108 \\
18 \mathrm{~B} \\
440.9 \\
\text { Vesicle } \\
\text { Massive } \\
\text { Chab } \\
\text { M37 }\end{array}$ & $\begin{array}{c}28 \mathrm{R}-1 \\
107-108 \\
18 \mathrm{~B} \\
440.9 \\
\text { Vesicle } \\
\text { Massive } \\
\text { Chab } \\
\text { M53 }\end{array}$ \\
\hline $\begin{array}{l}\mathrm{SiO}_{2} \\
\mathrm{Al}_{2} \mathrm{O}_{3} \\
\mathrm{FeO}_{5} \\
\mathrm{MnO} \\
\mathrm{MgO} \\
\mathrm{CaO} \\
\mathrm{Na}_{2} \mathrm{O} \\
\mathrm{K}_{2} \mathrm{O} \\
\text { Total }\end{array}$ & $\begin{array}{r}59.84 \\
17.78 \\
1.48 \\
0.00 \\
1.78 \\
2.64 \\
2.90 \\
4.67 \\
91.08\end{array}$ & $\begin{array}{r}61.25 \\
18.73 \\
0.91 \\
0.00 \\
1.27 \\
2.69 \\
3.13 \\
4.95 \\
92.93\end{array}$ & $\begin{array}{r}60.63 \\
18.91 \\
0.64 \\
0.00 \\
0.49 \\
3.30 \\
3.34 \\
4.84 \\
92.15\end{array}$ & $\begin{array}{r}57.78 \\
18.63 \\
0.31 \\
0.00 \\
0.28 \\
0.40 \\
6.20 \\
6.72 \\
90.33\end{array}$ & $\begin{array}{r}57.98 \\
18.53 \\
0.19 \\
0.00 \\
0.06 \\
0.59 \\
6.49 \\
7.13 \\
90.95\end{array}$ & $\begin{array}{r}60.74 \\
18.90 \\
0.34 \\
0.00 \\
0.23 \\
0.36 \\
6.05 \\
6.55 \\
93.16\end{array}$ & $\begin{array}{r}54.37 \\
20.02 \\
0.26 \\
0.00 \\
0.00 \\
4.46 \\
7.58 \\
0.81 \\
87.49\end{array}$ & $\begin{array}{r}55.10 \\
20.87 \\
0.57 \\
0.00 \\
0.39 \\
3.97 \\
5.23 \\
2.90 \\
89.02\end{array}$ & $\begin{array}{r}50.38 \\
19.80 \\
0.36 \\
0.00 \\
0.16 \\
3.63 \\
5.42 \\
2.76 \\
82.50\end{array}$ & $\begin{array}{r}54.98 \\
20.73 \\
0.23 \\
0.00 \\
0.00 \\
4.21 \\
7.14 \\
0.49 \\
87.77\end{array}$ & $\begin{array}{r}52.44 \\
20.63 \\
0.09 \\
0.00 \\
0.00 \\
3.90 \\
6.52 \\
3.05 \\
86.63\end{array}$ \\
\hline $\begin{array}{l}\mathrm{Si} \\
\mathrm{Al} \\
\mathrm{Fe}_{1} \\
\mathrm{Mn} \\
\mathrm{Mg} \\
\mathrm{Ca} \\
\mathrm{Na} \\
\mathrm{K} \\
\text { Total }\end{array}$ & $\begin{array}{r}11.71 \\
4.10 \\
0.15 \\
0.00 \\
0.52 \\
0.55 \\
1.10 \\
1.17 \\
19.30\end{array}$ & $\begin{array}{r}11.69 \\
4.21 \\
0.14 \\
0.00 \\
0.36 \\
0.55 \\
1.16 \\
1.20 \\
19.31\end{array}$ & $\begin{array}{r}11.66 \\
4.28 \\
0.14 \\
0.00 \\
0.14 \\
0.68 \\
1.24 \\
1.19 \\
19.34\end{array}$ & $\begin{array}{r}11.50 \\
4.37 \\
0.15 \\
0.00 \\
0.08 \\
0.08 \\
2.39 \\
1.71 \\
20.29\end{array}$ & $\begin{array}{r}11.50 \\
4.33 \\
0.15 \\
0.00 \\
0.02 \\
0.12 \\
2.49 \\
1.80 \\
20.41\end{array}$ & $\begin{array}{r}11.65 \\
4.27 \\
0.14 \\
0.00 \\
0.07 \\
0.07 \\
2.25 \\
1.60 \\
20.06\end{array}$ & $\begin{array}{r}11.02 \\
4.78 \\
0.15 \\
0.00 \\
0.00 \\
0.97 \\
2.98 \\
0.21 \\
20.11\end{array}$ & $\begin{array}{r}11.02 \\
4.92 \\
0.15 \\
0.00 \\
0.12 \\
0.85 \\
2.03 \\
0.74 \\
19.83\end{array}$ & $\begin{array}{r}10.89 \\
5.04 \\
0.16 \\
0.00 \\
0.05 \\
0.84 \\
2.27 \\
0.76 \\
20.02\end{array}$ & $\begin{array}{r}11.03 \\
4.90 \\
0.15 \\
0.00 \\
0.00 \\
0.91 \\
2.78 \\
0.12 \\
19.89\end{array}$ & $\begin{array}{r}10.83 \\
5.02 \\
0.16 \\
0.00 \\
0.00 \\
0.86 \\
2.61 \\
0.80 \\
20.29\end{array}$ \\
\hline $\begin{array}{l}\mathrm{Si} / \mathrm{Al} \\
\mathrm{E} \%\end{array}$ & $\begin{array}{r}2.86 \\
-3.74\end{array}$ & $\begin{array}{l}2.78 \\
4.12\end{array}$ & $\begin{array}{l}2.72 \\
8.65\end{array}$ & $\begin{array}{l}2.63 \\
1.87\end{array}$ & $\begin{array}{r}2.66 \\
-2.21\end{array}$ & $\begin{array}{l}2.73 \\
6.90\end{array}$ & $\begin{array}{r}2.31 \\
-3.68\end{array}$ & $\begin{array}{l}2.24 \\
7.84\end{array}$ & $\begin{array}{l}2.16 \\
8.08\end{array}$ & $\begin{array}{l}2.25 \\
7.22\end{array}$ & $\begin{array}{l}2.16 \\
0.69\end{array}$ \\
\hline
\end{tabular}

Notes: Formulas are calculated on the basis of 32 oxygens. Phill $=$ phillipsite, $\mathrm{Chab}=$ chabazite, and $\mathrm{Rad}$ fib $=$ radiating fibers. $\mathrm{E} \%=100\{\mathrm{~A}]-[\mathrm{Na}+\mathrm{K}+2(\mathrm{Ca}+\mathrm{Mg}+\mathrm{Sr}+\mathrm{Ba})] / \mathrm{Na}$ $+\mathrm{K}+2(\mathrm{Ca}+\mathrm{Mg}+\mathrm{Sr}+\mathrm{Ba})\}$ (Passaglia, 1970). 
Table 13. Representative palagonite and fresh glass analyses, Hole 896A.

\begin{tabular}{|c|c|c|c|c|c|c|c|c|c|c|c|c|}
\hline Core, section: & $28 \mathrm{R}-1$ & $9 \mathrm{R}-2$ & $9 \mathrm{R}-2$ & $9 \mathrm{R}-2$ & $18 \mathrm{R}-1$ & 18R-2 & 18R-2 & 18R-2 & 18R-2 & $18 \mathrm{R}-2$ & $18 \mathrm{R}-2$ & $18 \mathrm{R}-2$ \\
\hline Interval $(\mathrm{cm})$ : & $107-108$ & $14-17$ & $14-17$ & $14-17$ & $87-90$ & $87-92$ & $87-92$ & $87-92$ & $87-92$ & $87-92$ & $87-92$ & $87-92$ \\
\hline Piece no.: & $18 \mathrm{~B}$ & 2 & 2 & 2 & $9 \mathrm{~A}$ & $9 \mathrm{~A}$ & $9 A^{-}$ & $9 \mathrm{~A}$ & $9 \mathrm{~A}$ & $9 \mathrm{~A}$ & $9 \mathrm{~A}$ & $9 \mathrm{~A}$ \\
\hline Depth (mbsf): & 440.9 & 268.2 & 268.2 & 268.2 & 353.2 & 354.2 & 354.2 & 354.2 & 354.2 & 354.2 & 354.2 & 354.2 \\
\hline Palag type: & & $\mathrm{Br}-\mathrm{p}$ grn & $\mathrm{Br}-\mathrm{p}$ grn & Gran-p grn & Br subis & Br subis & $\mathrm{Fib}$ & Fib & $\mathrm{Fib}$ & $\mathrm{Fib}$ & $\mathrm{Fib}$ & $\mathrm{Fib}$ \\
\hline Occurrence: & Fr glass & Glass & Glass & Glass & Glass & Glass & Glass & Glass & Glass & Glass & Glass & Glass \\
\hline Analysis no.: & M 68 & $\mathrm{M} 114$ & MII5 & MII 6 & M98 & M99 & $\mathrm{M} 102$ & M103 & MI04 & M105 & M106 & M107 \\
\hline $\mathrm{SiO}_{2}$ & 49.88 & 44.54 & 46.30 & 47.94 & 47.52 & 51.44 & 46.57 & 43.90 & 42.95 & 38.48 & 37.71 & 39.67 \\
\hline $\mathrm{Al}, \mathrm{O}$, & 16.16 & 15.77 & 16.64 & 16.18 & 1582 & 15.94 & 15.60 & 15.57 & 14.99 & 15.04 & 15.09 & 15.19 \\
\hline $\mathrm{FeO}$ & 8.17 & 10.20 & 9.43 & 9.33 & 5.67 & 5.22 & 7.21 & 9.05 & 10.24 & 13.41 & 12.78 & 12.40 \\
\hline $\mathrm{MnO}$ & 0.84 & 0.33 & 0.25 & 0.24 & 0.13 & 0.08 & 0.64 & 0.16 & 0.21 & 0.32 & 0.57 & 0.48 \\
\hline $\mathrm{MgO}$ & 9.09 & 9.86 & 7.45 & 7.66 & 4.80 & 4.56 & 6.94 & 9.34 & 11.30 & 14.35 & 14.30 & 12.78 \\
\hline $\mathrm{CaO}$ & 13.24 & 2.28 & 4.76 & 8.23 & 2.25 & 2.65 & 2.06 & 1.86 & 1.78 & 1.34 & 1.44 & 1.44 \\
\hline $\mathrm{Na}, \mathrm{O}$ & 1.56 & 7.28 & 3.15 & 2.76 & 6.07 & 3.67 & 7.12 & 3.92 & 2.90 & 2.63 & 2.97 & 1.12 \\
\hline $\mathrm{K}_{2} \mathrm{O}$ & 0.01 & 1.62 & 1.18 & 1.01 & 1.03 & 0.90 & 1.12 & 0.76 & 0.50 & 0.44 & 0.27 & 0.29 \\
\hline TiO & 0.62 & 0.85 & 0.83 & 0.83 & 0.92 & 1.04 & 0.88 & 1.28 & 0.87 & 1.35 & 1.64 & 0.89 \\
\hline $\mathrm{Cr}_{2} \mathrm{O}_{3}$ & 0.00 & 0.05 & 0.04 & 0.00 & 0.08 & 0.00 & 0.22 & 0.10 & 0.02 & 0.03 & 0.04 & 0.00 \\
\hline Total & 99.56 & 92.77 & 90.03 & 94.18 & 84.28 & 85.50 & 88.36 & 85.94 & 85.74 & 87.40 & 86.81 & 84.26 \\
\hline
\end{tabular}

Table 13 (continued).

\begin{tabular}{|c|c|c|c|c|c|c|c|c|c|c|c|c|c|}
\hline Core, section: & $28 \mathrm{R}-1$ & $28 \mathrm{R}-1$ & $28 \mathrm{R}-1$ & 28R-1 & 28R-1 & 28R-I & 28R-I & $28 \mathrm{R}-1$ & $28 \mathrm{R}-1$ & 28R-1 & 28R-1 & $28 \mathrm{R}-1$ & $28 \mathrm{R}-1$ \\
\hline Interval $(\mathrm{cm})$ : & $107-108$ & $107-108$ & $107-108$ & $107-108$ & $107-108$ & $107-108$ & $107-108$ & $107-108$ & $107-108$ & $107-108$ & $107-108$ & $107-108$ & $107-108$ \\
\hline Piece no.: & 18B & 18B & 18B & I8B & 18B & 18B & 18B & 18B & I8B & 18B & $18 \mathrm{~B}$ & 18B & $18 \mathrm{~B}$ \\
\hline Depth (mbsf): & 440.9 & 440.9 & 440.9 & 440.9 & 440.9 & 440.9 & 440.9 & 440.9 & 440.9 & 440.9 & 440.9 & 440.9 & 440.9 \\
\hline Palag type: & Br subis & Fib & Fib & Br subis & Br subis & Gran br & Gran br & Grn & Grn & Grn & $\mathrm{Fib}$ & $\mathrm{Fib}$ & Fib \\
\hline Occurrence: & Glass & Glass & Glass & Glass & Glass & Glass & Glass & Glass & Glass & Glass & Vein & Vein & Vein \\
\hline Analysis no.: & M41 & M38 & M58 & M70 & M69 & M71 & M72 & M73 & M74 & M75 & M77 & M79 & M78 \\
\hline $\mathrm{SiO}_{2}$ & 53.64 & 37.10 & 39.40 & 46.50 & 50.12 & 50.01 & 46.70 & 41.36 & 39.73 & 39.09 & 40.93 & 41.28 & 42.04 \\
\hline $\mathrm{Al}_{2} \mathrm{O}_{3}$ & 16.96 & 16.40 & 13.93 & 14.80 & 17.02 & 17.62 & 17.18 & 16.09 & 15.98 & 16.23 & 16.15 & 15.41 & 17.72 \\
\hline $\mathrm{FeO}$ & 6.59 & 11.48 & 10.80 & 8.18 & 7.55 & 7.87 & 9.08 & 10.61 & 10.83 & 10.29 & 11.00 & 12.34 & 9.01 \\
\hline $\mathrm{MnO}$ & 0.06 & 0.00 & 0.21 & 0.05 & 0.00 & 0.55 & 0.00 & 0.21 & 0.18 & 0.28 & 0.00 & 0.07 & 0.26 \\
\hline $\mathrm{MgO}$ & 6.40 & 17.45 & 14.90 & 8.26 & 5.14 & 6.95 & 8.30 & 12.81 & 14.70 & 13.91 & 14.10 & 11.53 & 13.18 \\
\hline $\mathrm{CaO}$ & 7.01 & 2.71 & 3.21 & 13.12 & 6,93 & 4.78 & 4.21 & 2.85 & 2.80 & 2.81 & 2.67 & 2.82 & 3.06 \\
\hline $\mathrm{Na}_{2} \mathrm{O}$ & 1.06 & 0.29 & 0.42 & 1.47 & 0.89 & 0.64 & 0.73 & 0.33 & 0.19 & 0.16 & 0.18 & 0.13 & 0.09 \\
\hline $\mathrm{K}_{2} \mathrm{O}$ & 0.51 & 0.07 & 0.33 & 0.03 & 0.48 & 0.49 & 0.49 & 0.20 & 0.16 & 0.22 & 0.30 & 0.74 & 0.26 \\
\hline $\mathrm{TiO}_{2}$ & 0.64 & 0.00 & 1.53 & 0.58 & 0.79 & 0.79 & 1.77 & 0.58 & 0.25 & 0.46 & 0.13 & 0.16 & 0.07 \\
\hline $\mathrm{Cr}_{2} \mathrm{O}_{2}$ & 0.08 & 0.00 & 0.00 & 0.00 & 0.00 & 0.27 & 0.00 & 0.22 & 0.00 & 0.00 & 0.00 & 0.00 & 0.49 \\
\hline Total & 92.94 & 85.49 & 84.73 & 92.98 & 88.91 & 89.96 & 88.44 & 85.25 & 84.82 & 83.45 & 85.47 & 84.47 & 86.16 \\
\hline
\end{tabular}

Notes: $\mathrm{Palag}=$ palagonite, $\mathrm{Br}-\mathrm{p}$ grn $=$ brown-pale green. Gran-p grn $=$ granulose - pale green, $\mathrm{Br}$ subis $=$ brown subistropic, Fib $=$ fibrous, Gran br $=$ granulose brown, Grn $=$ green, and $\mathrm{Fr}$ glass $=$ fresh glass.

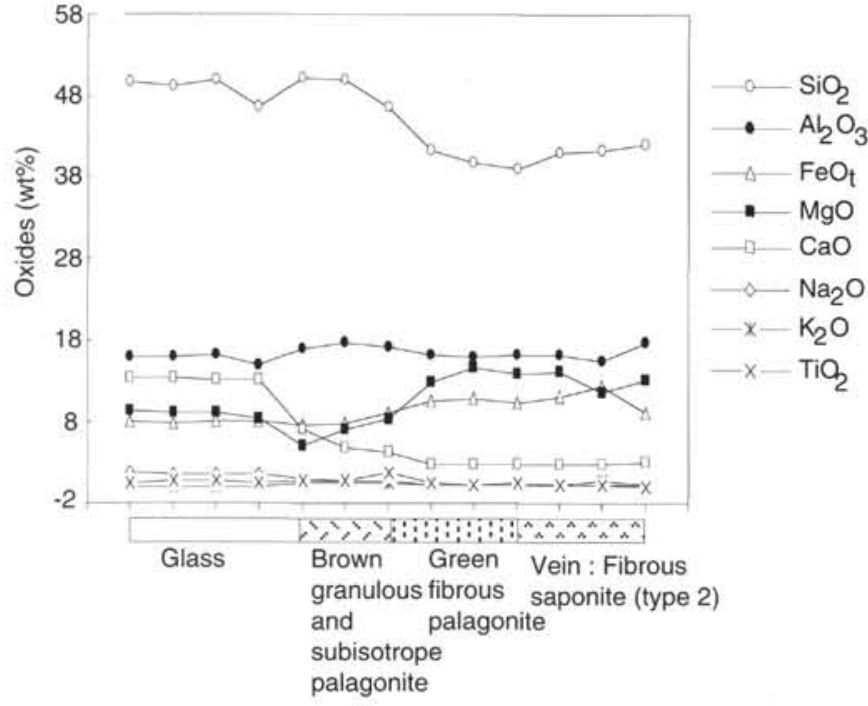

Figure 10. Chemical composition of glass, "palagonite" replacing glass, and veinlet in Sample 148-896A-28R-1, 107-108 cm, Piece 18B.

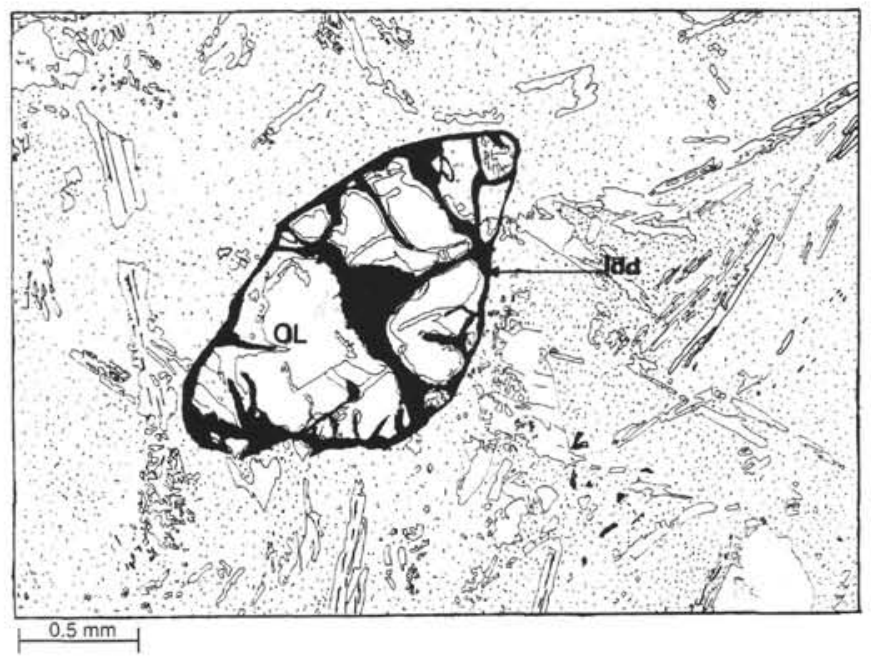

Figure 11. Sketch of a thin section showing the rim of an olivine phenocryst replaced by iddingsite (type $8 \mathrm{~b}$ ), while the core $(\mathrm{OL})$ remains unaltered. Sample 148-896A-3R-1, 143-146 cm, Piece 17. Scale bar $=0.5 \mathrm{~mm}$. 
Table 14. Secondary mineralogy of composite red halos and gray adjacent basalt from Hole 896A.

\begin{tabular}{|c|c|c|}
\hline Primary mineral or void & Composite red halo, Zone A & Composite red halo, Zone B \\
\hline Olivine & Saponite (types 1,2 ) + celadonitic minerals (types 4,5 ) \pm iddingsite (type 8 b) & Iddingsite (type 8 b) + saponite (types 1,2$) \pm$ aragonite \pm calcite \\
\hline Clinopyroxene & Fresh phenocrysts and microphenocrysts, plumoses replaced by Fe-oxyhydroxides & $\begin{array}{l}\text { Fresh phenocrysts and microphenocrysts, plumoses replaced by } \\
\text { Fe-oxyhydroxides }\end{array}$ \\
\hline Plagioclase & Fresh, slightly replaced by saponite (type 2 ) when in contact with a saponite vein & $\begin{array}{l}\text { Fresh, slightly replaced by saponite (type } 2 \text { ) when in contact } \\
\text { with a saponite vein }\end{array}$ \\
\hline Titanomagnetite & Titanomaghemite & Titanomaghemite \\
\hline Cr-spinel & Fresh & Fresh \\
\hline Vesicles & $\begin{array}{l} \pm \text { Iddingsite (type } 8 b)+ \text { celadonitic minerals (types } 3,4,5) \pm \text { saponite (types } 1,2) \pm \\
\text { aragonite } \pm \text { calcite }\end{array}$ & $\begin{array}{l}\text { Iddingsite (type } 8 \mathrm{~b} \text { ) }+ \text { saponite (types } 1,2) \pm \text { aragonite } \pm \text { calcite } \\
\pm \text { iddingsite (type } 8 \mathrm{a} \text { ?) and saponite (type } 7 \mathrm{~b} \text { ) }\end{array}$ \\
\hline Interstitial areas & Iddingsite (type 8 b) + celadonitic minerals (types 4,5 ) + saponite (types 1,2 ) & Iddingsite (type $8 b$ ) + saponite (types 1,2$) \pm$ aragonite \pm calcite \\
\hline
\end{tabular}

Table 14 (continued).

\begin{tabular}{|c|c|c|}
\hline Primary mineral or void & Composite red halo, Zone C & Gray adjacent basalt \\
\hline Olivine & Iddingsite (type $8 b)+$ saponite (types 1,2$) \pm$ aragonite \pm calcite & Saponite (types 1,2 ) \pm pyrite \\
\hline Clinopyroxene & Fresh pheno- and microphenocrysts, plumoses replaced by Fe-oxyhydroxides & Fresh \\
\hline Plagioclase & Fresh, slightly replaced by saponite when in contact with a saponite vein & $\begin{array}{l}\text { Fresh, slightly replaced by saponite when in contact with a } \\
\text { saponite vein }\end{array}$ \\
\hline Titanomagnetite & Titanomaghemite & Titanomaghemite \\
\hline Cr-spinel & & Fresh \\
\hline Vesicles & Iddingsite (type $8 \mathrm{~b})+$ saponite (types 1,2$) \pm$ aragonite \pm calcite \pm iddingsite (type $8 \mathrm{a}$ ) & Saponite (types 1,2$) \pm$ aragonite \pm calcite \\
\hline Interstitial areas & Iddingsite (type $8 b)+$ saponite (types 1,2$) \pm$ aragonite \pm calcite & Saponite (types 1, 2) \\
\hline
\end{tabular}

Table 15. Secondary mineralogy of simple red halos and gray adjacent basalt from Hole 896A.

\begin{tabular}{|c|c|c|}
\hline Primary mineral or void & Red halo & Gray adjacent basalt \\
\hline Olivine & Iddingsite (type $8 b$ ) at the rim + saponite (types 1,2 ) at the center, \pm calcite \pm aragonite in the center & Saponite (types 1,2$) \pm$ calcite \pm aragonite \\
\hline Clinopyroxene & Fresh & Fresh \\
\hline Plagioclase & Fresh, core rarely replaced by saponite (type 2 ) & Fresh, core rarely replaced by saponite (type 2 ) \\
\hline Titanomagnetite & Titanomaghemite & Titanomaghemite \\
\hline Cr-spinel & Fresh & Fresh \\
\hline Vesicles & \pm Iddingsite (type $8 b)+$ saponite (types 1,2 ) \pm calcite \pm aragonite & Saponite (types 1,2$) \pm$ aragonite \pm calcite \pm pyrite \\
\hline Interstitial areas & Iddingsite (type $8 \mathrm{~b}$ ) + saponite (types 1,2 ) \pm chlorite/saponite (type 6 ) & Saponite (types 1,2 ) \\
\hline
\end{tabular}

Table 16. Secondary mineralogy of brown halos and gray adjacent basalt from Hole 896A.

\begin{tabular}{lll}
\hline Primary mineral or void & \multicolumn{1}{c}{ Brown halo } & Gray adjacent basalt \\
\hline Olivine & Saponite + iddingsite (type $8 \mathrm{~b}) \pm$ celadonite (type 5) & Saponite \pm calcite \pm aragonite \\
Clinopyroxene & Fresh phenocrysts and microphenocrysts plumoses replaced by Fe-oxyhydroxides & Fresh \\
Plagioclase & Fresh, slightly replaced by saponite when in contact with saponite veins & Fresh, slightly replaced by saponite when in contact with saponite veins \\
Titanomagnetite & Titanomaghemite & Titanomaghemite \\
Cr-spinel & Fresh & Fresh \\
Vesicles & Saponite (type ?) \pm celadonitic compound (type 4 and/or 5) \pm iddingsite (type 8b) Saponite \pm calcite \pm aragonite \\
Interstitial areas & Saponite (type ?) \pm celadonitic compound (type 4 and/or 5) \pm iddingsite (type 8b) Saponite & \\
\hline
\end{tabular}

Table 17. Secondary mineralogy of black halos and gray adjacent basalt from Hole 896A.

\begin{tabular}{|c|c|c|}
\hline Primary mineral or void & Black halo & Gray adjacent basalt \\
\hline Olivine & $\begin{array}{l}\text { Celadonitic minerals (types } 3,5,7 \text { a) at the rim, saponite (types 1,2) in the center: } \\
\text { iddingsite (type 7a) at the rim, saponite (types } 1,2 \text { ) in the center }\end{array}$ & Saponite (types 1,2) \\
\hline Clinopyroxene & Fresh & Fresh \\
\hline Plagioclase & Fresh. slightly replaced by saponite (type 2 ) when in contact with a saponite vein & $\begin{array}{l}\text { Fresh, slightly replaced by saponite (type } 2 \text { ) when in contact } \\
\text { with a saponite vein }\end{array}$ \\
\hline Titanomagnetite & \multirow{4}{*}{$\begin{array}{l}\text { Titanomaghemite } \\
\text { Fresh } \\
\pm \text { Iddingsite (type } 8 \text { b) }+ \text { celadonitic minerals (types } 3,4,5 \text { ) + saponite (types } 1,2 \text { ) } \pm \\
\text { pyrite } \\
\text { Celadonite (types } 3,4)+ \text { saponite (types } 1,2 \text { ) } \pm \text { iddingsite (type } 8 \text { b) }\end{array}$} & Titanomaghemite \\
\hline Cr-spinel & & Fresh \\
\hline Vesicles & & Saponite (types 1,2) \\
\hline Interstitial areas & & Saponite (types 1,2) \\
\hline
\end{tabular}


Table 18. Bulk-rock chemical analyses, Hole 896A.

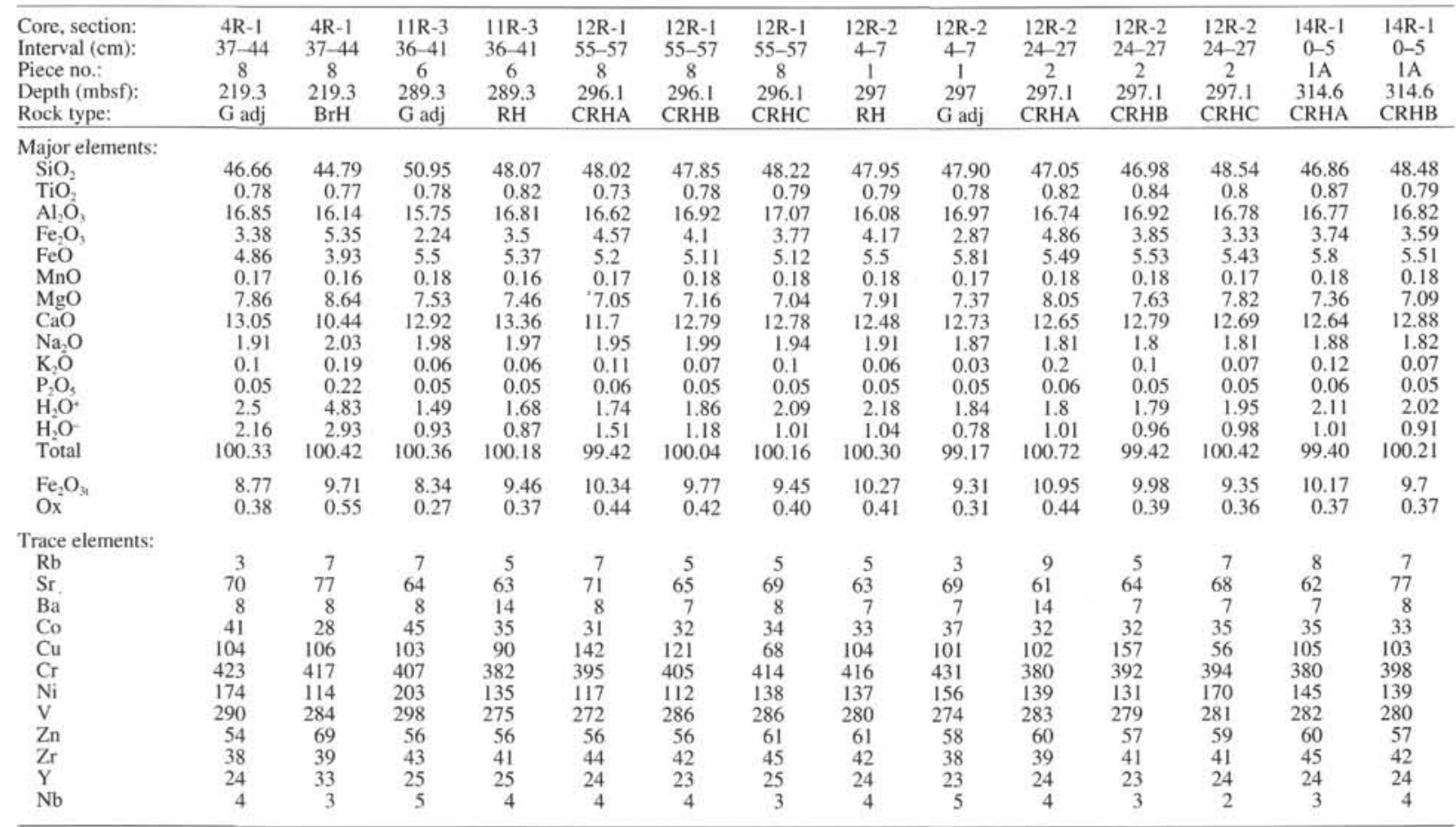

Table 18 (continued).

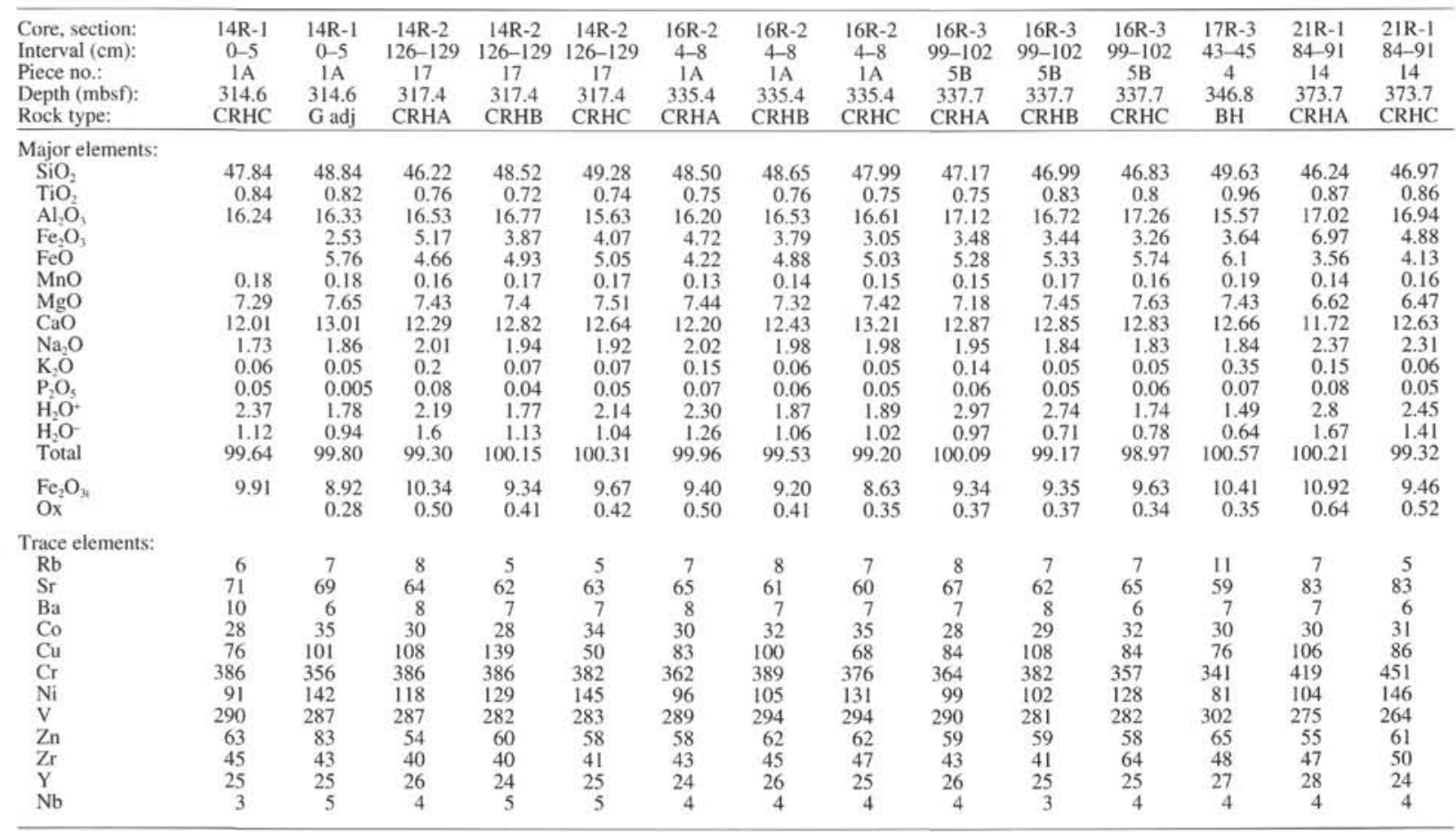


Table 18 (continued).

\begin{tabular}{|c|c|c|c|c|c|c|c|c|c|c|c|c|c|c|}
\hline $\begin{array}{l}\text { Core, section: } \\
\text { Interval }(\mathrm{cm}): \\
\text { Piece no.: } \\
\text { Depth (mbsf): } \\
\text { Rock type: }\end{array}$ & $\begin{array}{c}21 R-1 \\
84-91 \\
14 \\
373.7 \\
G \text { adj }\end{array}$ & $\begin{array}{c}21 \mathrm{R}-2 \\
47-50 \\
6 \\
374.9 \\
\text { CRHB }\end{array}$ & $\begin{array}{c}21 \mathrm{R}-2 \\
47-50 \\
6 \\
374.9 \\
\text { CRHC }\end{array}$ & $\begin{array}{c}2 I R-2 \\
66-69 \\
8 \\
375.1 \\
G \text { adj }\end{array}$ & $\begin{array}{c}21 \mathrm{R}-2 \\
66-69 \\
8 \\
375.1 \\
\mathrm{RH}\end{array}$ & $\begin{array}{c}22 \mathrm{R}-1 \\
12-15 \\
2 \\
382.7 \\
\text { CRHA }\end{array}$ & $\begin{array}{c}22 \mathrm{R}-1 \\
12-15 \\
2 \\
382.7 \\
\text { CRHB,C }\end{array}$ & $\begin{array}{l}22 \mathrm{R}-1 \\
12-15 \\
2 \\
382.7 \\
G \text { adj }\end{array}$ & $\begin{array}{c}23 \mathrm{R}-1 \\
103-106 \\
15 \\
393.2 \\
\mathrm{BrH}\end{array}$ & $\begin{array}{c}23 R-2 \\
0-6 \\
\text { IA } \\
393.6 \\
\text { CRHA }\end{array}$ & $\begin{array}{c}23 R-2 \\
0-6 \\
1 \mathrm{~A} \\
393.6 \\
\text { CRHB }\end{array}$ & $\begin{array}{c}23 R-2 \\
0-6 \\
1 \mathrm{~A} \\
393.6 \\
\text { CRHC }\end{array}$ & $\begin{array}{l}23 R-2 \\
0-6 \\
\text { IA } \\
393.6 \\
\text { G adj }\end{array}$ & $\begin{array}{c}44 \text { Bas- } 148 \\
40279\end{array}$ \\
\hline $\begin{array}{l}\text { Major elements: } \\
\mathrm{SiO}_{2} \\
\mathrm{TiO}_{2} \\
\mathrm{Al}_{2} \mathrm{O}_{3} \\
\mathrm{Fe}_{2} \mathrm{O}_{3} \\
\mathrm{FeO} \\
\mathrm{MnO} \\
\mathrm{MgO} \\
\mathrm{CaO} \\
\mathrm{Na}_{2} \mathrm{O} \\
\mathrm{K}_{2} \mathrm{O} \\
\mathrm{P}_{2} \mathrm{O}_{4} \\
\mathrm{H}_{2} \mathrm{O}^{+} \\
\mathrm{H}_{2} \mathrm{O}^{-} \\
\mathrm{Total}^{+}\end{array}$ & $\begin{array}{r}48.13 \\
1.01 \\
17.57 \\
2.93 \\
4.29 \\
0.16 \\
6.57 \\
12.93 \\
2.39 \\
0.05 \\
0.05 \\
2.25 \\
0.98 \\
99.31\end{array}$ & $\begin{array}{r}46.55 \\
0.93 \\
17.29 \\
4.48 \\
4.91 \\
0.19 \\
7.35 \\
12.89 \\
2.13 \\
0.06 \\
0.05 \\
2.09 \\
0.62 \\
99.54\end{array}$ & $\begin{array}{c}45.8 \\
0.89 \\
17.11 \\
5.33 \\
4.46 \\
0.18 \\
7.97 \\
13.02 \\
2.18 \\
0.05 \\
0.06 \\
2.5 \\
0.72 \\
100.27\end{array}$ & $\begin{array}{c}47.51 \\
0.9 \\
17.3 \\
2.36 \\
5.07 \\
0.15 \\
7.78 \\
13.2 \\
2.29 \\
0.04 \\
0.05 \\
2.58 \\
1.25 \\
100.48\end{array}$ & $\begin{array}{r}45.33 \\
0.87 \\
17.54 \\
5.16 \\
4.64 \\
0.17 \\
7.82 \\
12.92 \\
2.24 \\
0.04 \\
0.05 \\
1.8 \\
1.05 \\
99.63\end{array}$ & $\begin{array}{r}48.62 \\
0.94 \\
15.02 \\
4.63 \\
5.62 \\
0.18 \\
7.61 \\
12.14 \\
2 \\
0.13 \\
0.13 \\
1.78 \\
1.4 \\
100.20\end{array}$ & $\begin{array}{r}47.78 \\
0.89 \\
15.87 \\
4.19 \\
6.03 \\
0.19 \\
7.52 \\
12.62 \\
1.92 \\
0.06 \\
0.07 \\
1.83 \\
0.65 \\
99.62\end{array}$ & $\begin{array}{r}50.51 \\
0.87 \\
15.75 \\
1.49 \\
7.41 \\
0.19 \\
7.71 \\
12.91 \\
0.93 \\
0.03 \\
0.06 \\
2.13 \\
0.62 \\
100.61\end{array}$ & $\begin{array}{r}44.98 \\
0.85 \\
17.75 \\
5.76 \\
3.72 \\
0.13 \\
7.04 \\
10.56 \\
2.47 \\
0.17 \\
0.11 \\
2.96 \\
2.57 \\
99.07\end{array}$ & $\begin{array}{r}47.05 \\
0.77 \\
17.22 \\
4.67 \\
4.35 \\
0.15 \\
6.52 \\
11.85 \\
2.18 \\
0.18 \\
0.07 \\
1.86 \\
1.82 \\
98.69\end{array}$ & $\begin{array}{c}47.8 \\
0.81 \\
16.88 \\
4.7 \\
4.51 \\
0.17 \\
7.15 \\
11.64 \\
2.18 \\
0.04 \\
0.05 \\
1.95 \\
1.58 \\
99.46\end{array}$ & $\begin{array}{r}48.12 \\
0.83 \\
16.52 \\
3.99 \\
4.55 \\
0.17 \\
7.17 \\
11.82 \\
2.15 \\
0.04 \\
0.05 \\
2.28 \\
1.43 \\
99.12\end{array}$ & $\begin{array}{r}48.94 \\
0.92 \\
18.06 \\
2.22 \\
4.77 \\
0.16 \\
7.01 \\
11.88 \\
2.21 \\
0.03 \\
0.05 \\
1.61 \\
1.22 \\
99.08\end{array}$ & $\begin{array}{r}49.09 \\
0.87 \\
15.82 \\
2.04 \\
6.85 \\
0.15 \\
8.63 \\
11.83 \\
1.96 \\
0.04 \\
0.07 \\
1.45 \\
0.19 \\
98.99\end{array}$ \\
\hline $\begin{array}{l}\mathrm{Fe}_{2} \mathrm{O}_{4} \\
\mathrm{Ox}\end{array}$ & $\begin{array}{l}7.69 \\
0.38\end{array}$ & $\begin{array}{l}9.93 \\
0.45\end{array}$ & $\begin{array}{r}10.28 \\
0.52\end{array}$ & $\begin{array}{l}7.98 \\
0.30\end{array}$ & $\begin{array}{r}10.31 \\
0.50\end{array}$ & $\begin{array}{r}10.86 \\
0.43\end{array}$ & $\begin{array}{r}10.88 \\
0.38\end{array}$ & $\begin{array}{l}9.71 \\
0.15\end{array}$ & $\begin{array}{l}9.88 \\
0.58\end{array}$ & $\begin{array}{l}9.49 \\
0.49\end{array}$ & $\begin{array}{l}9.7 \\
0.48\end{array}$ & $\begin{array}{l}9.04 \\
0.44\end{array}$ & $\begin{array}{l}7.51 \\
0.30\end{array}$ & $\begin{array}{l}9.64 \\
0.21\end{array}$ \\
\hline $\begin{array}{l}\text { Trace elements: } \\
\mathrm{Rb} \\
\mathrm{Sr} \\
\mathrm{Ba} \\
\mathrm{Co} \\
\mathrm{Cu} \\
\mathrm{Cr} \\
\mathrm{Ni} \\
\mathrm{V} \\
\mathrm{Zn} \\
\mathrm{Zr} \\
\mathrm{Y} \\
\mathrm{Nb}\end{array}$ & $\begin{array}{r}271 \\
61 \\
54 \\
22 \\
9\end{array}$ & $\begin{array}{r}7 \\
75 \\
7 \\
35 \\
105 \\
384 \\
127 \\
265 \\
61 \\
47 \\
25 \\
3\end{array}$ & $\begin{array}{r}7 \\
69 \\
6 \\
29 \\
85 \\
381 \\
129 \\
271 \\
59 \\
48 \\
25 \\
4\end{array}$ & $\begin{array}{r}7 \\
78 \\
6 \\
37 \\
99 \\
388 \\
150 \\
273 \\
66 \\
50 \\
23 \\
4\end{array}$ & $\begin{array}{r}8 \\
69 \\
7 \\
35 \\
103 \\
376 \\
140 \\
278 \\
61 \\
51 \\
26 \\
4\end{array}$ & $\begin{array}{r}7 \\
64 \\
8 \\
28 \\
58 \\
341 \\
87 \\
341 \\
73 \\
52 \\
32 \\
8\end{array}$ & $\begin{array}{r}8 \\
56 \\
7 \\
29 \\
84 \\
351 \\
92 \\
320 \\
67 \\
84 \\
27 \\
6\end{array}$ & $\begin{array}{r}6 \\
74 \\
11 \\
37 \\
94 \\
371 \\
148 \\
354 \\
56 \\
55 \\
25 \\
8\end{array}$ & $\begin{array}{r}7 \\
86 \\
9 \\
26 \\
77 \\
403 \\
87 \\
277 \\
66 \\
50 \\
32 \\
5\end{array}$ & $\begin{array}{r}11 \\
73 \\
7 \\
34 \\
100 \\
398 \\
89 \\
263 \\
54 \\
44 \\
27 \\
4\end{array}$ & $\begin{array}{r}5 \\
75 \\
6 \\
30 \\
87 \\
379 \\
125 \\
261 \\
59 \\
47 \\
25 \\
2\end{array}$ & $\begin{array}{r}7 \\
81 \\
6 \\
31 \\
99 \\
386 \\
161 \\
259 \\
56 \\
50 \\
26 \\
3\end{array}$ & $\begin{array}{r}7 \\
83 \\
6 \\
49 \\
101 \\
391 \\
209 \\
267 \\
61 \\
47 \\
26 \\
3\end{array}$ & $\begin{array}{r}7 \\
59 \\
7 \\
40 \\
92 \\
340 \\
124 \\
306 \\
53 \\
50 \\
28 \\
3\end{array}$ \\
\hline
\end{tabular}

Notes: Abbreviations as in Table 3, with the addition of $\mathrm{Std}=\mathrm{Leg} 148$ shipboard standard and $\mathrm{Ox}=\left[\left(\mathrm{Fe}_{2} \mathrm{O}_{3}\right) / 80\right] /\left[\left[\left(\mathrm{Fe}_{2} \mathrm{O}_{3}\right) / 80\right]+\left[\left(\mathrm{FeO}^{2}\right) / 72\right]\right\}$.
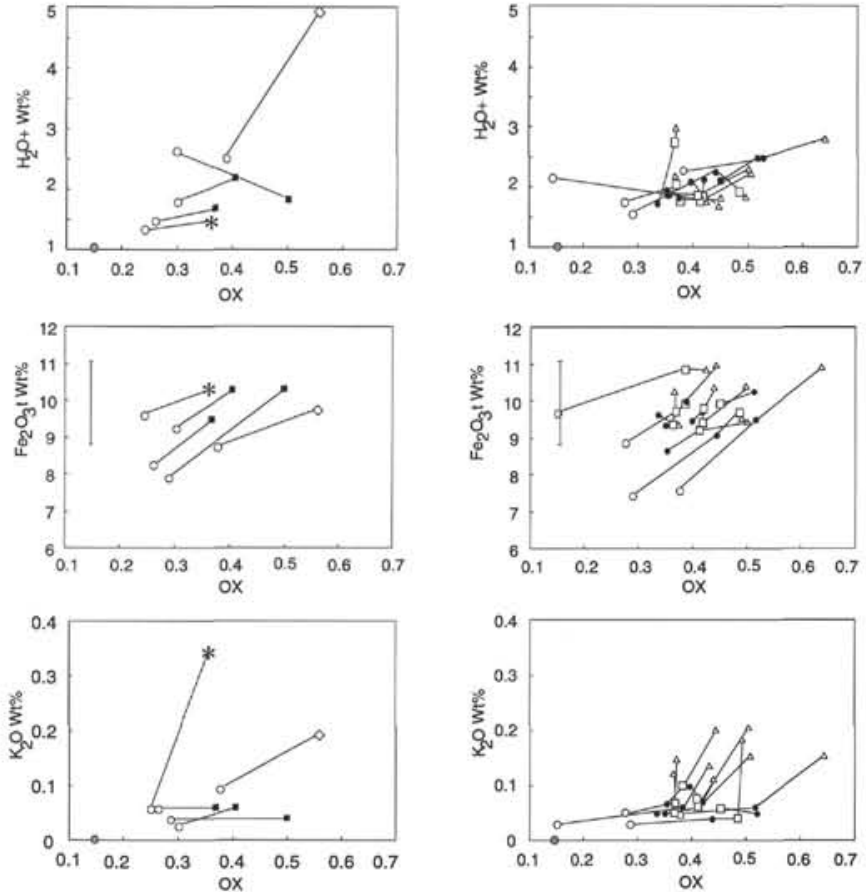

Figure 12. $\mathrm{H}_{2} \mathrm{O}^{+}, \mathrm{FeO}_{1}$, and $\mathrm{K}_{2} \mathrm{O}$ (wt \%) vs. $\mathrm{Ox}\left(=\mathrm{Fe}_{2} \mathrm{O}_{3} / \mathrm{Fe}_{2} \mathrm{O}_{3}+\mathrm{FeO}\right)$ in the various types of alteration halos from Hole $896 \mathrm{~A}$ basalts. Open circles $=$ gray adjacent basalt, solid squares $=$ red halos, diamond $=$ brown halo, asterisk $\left({ }^{*}\right)$ $=$ black halo, triangles $=$ Zone $\mathrm{A}$ of composite red halo, open squares $=$ Zone $\mathrm{B}$ of composite red halo, and solid circles $=$ Zone $\mathrm{C}$ of composite red halo. The lines link the halos with their adjacent gray rock. The average of $\mathrm{K}_{2} \mathrm{O}$ and $\mathrm{H}_{2} \mathrm{O}^{+}$and the range of $\mathrm{Fe}_{2} \mathrm{O}_{4}$ content of fresh glass samples are represented by a gray dot and a line, respectively. 